\title{
Manganese-Catalyzed and Mediated Synthesis of Arylphosphinates and Related Compounds
}

\author{
Olivier Berger, and Jean-Luc Montchamp* \\ Department of Chemistry, TCU Box 298860, Texas Christian University, \\ Fort Worth, Texas 76129 (USA)
}




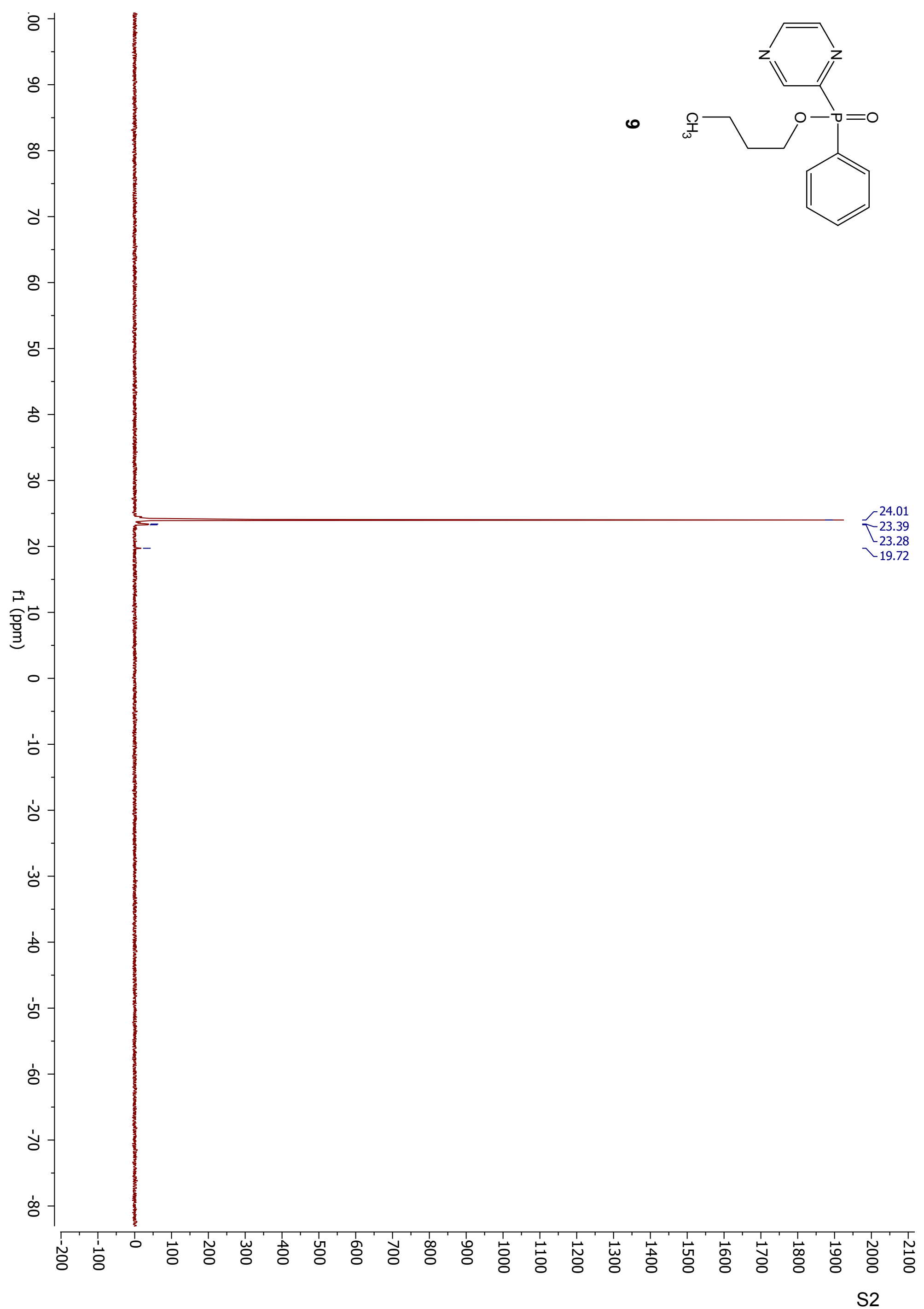




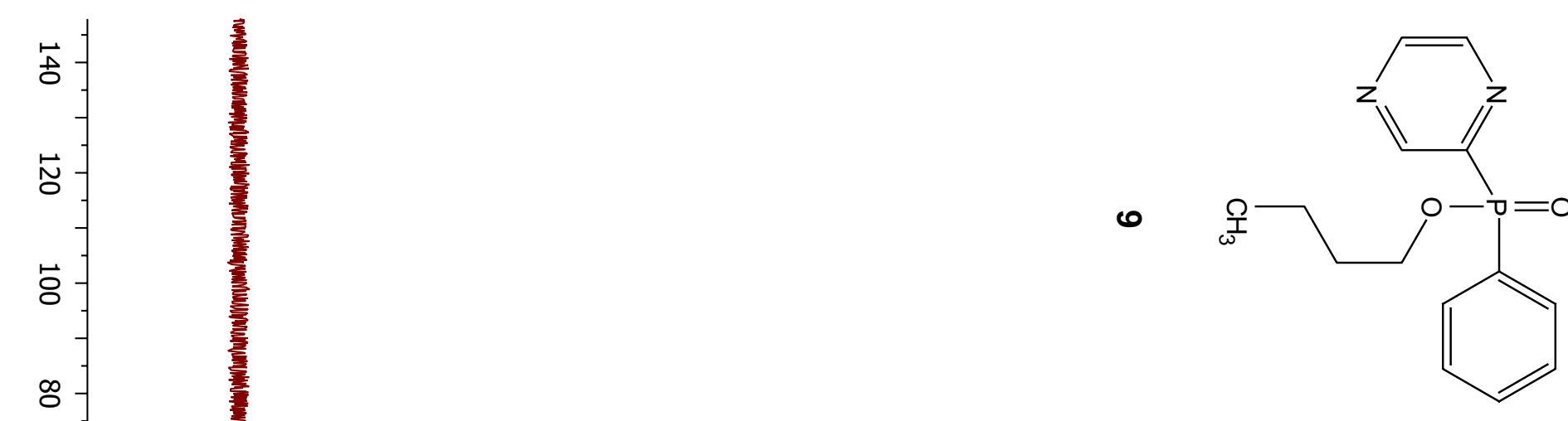

8

옹

ก

o

ஸ

$\stackrel{2}{\frac{0}{0}}$

엉

\&̊

s

s.

妾

횽

官

ஸั 

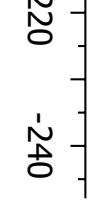

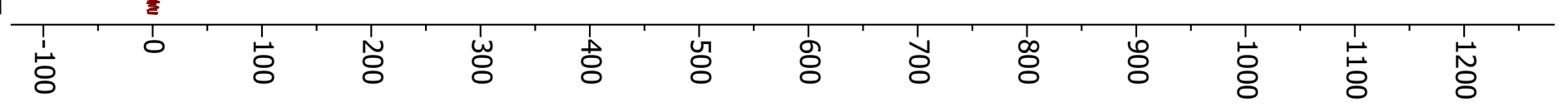




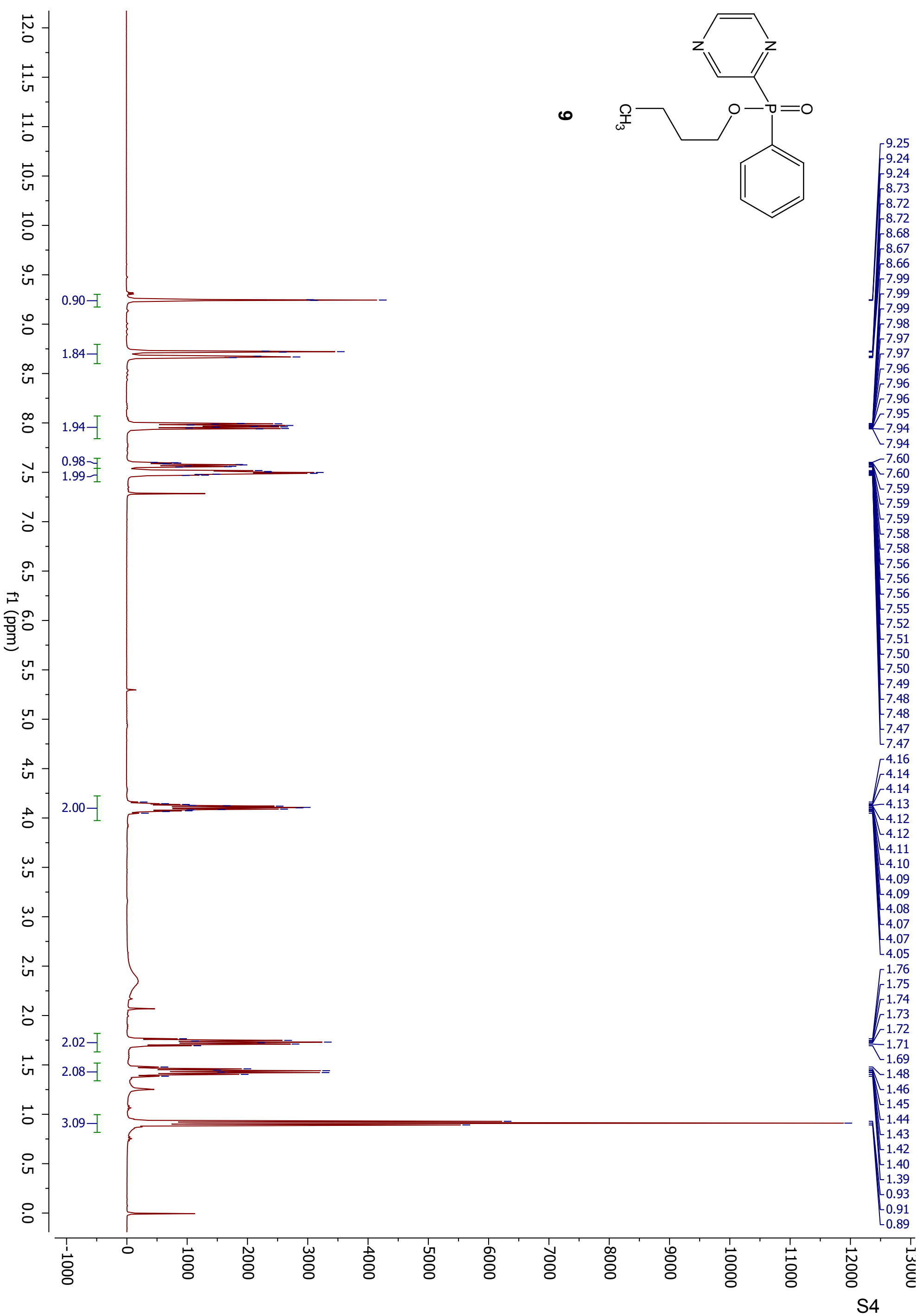




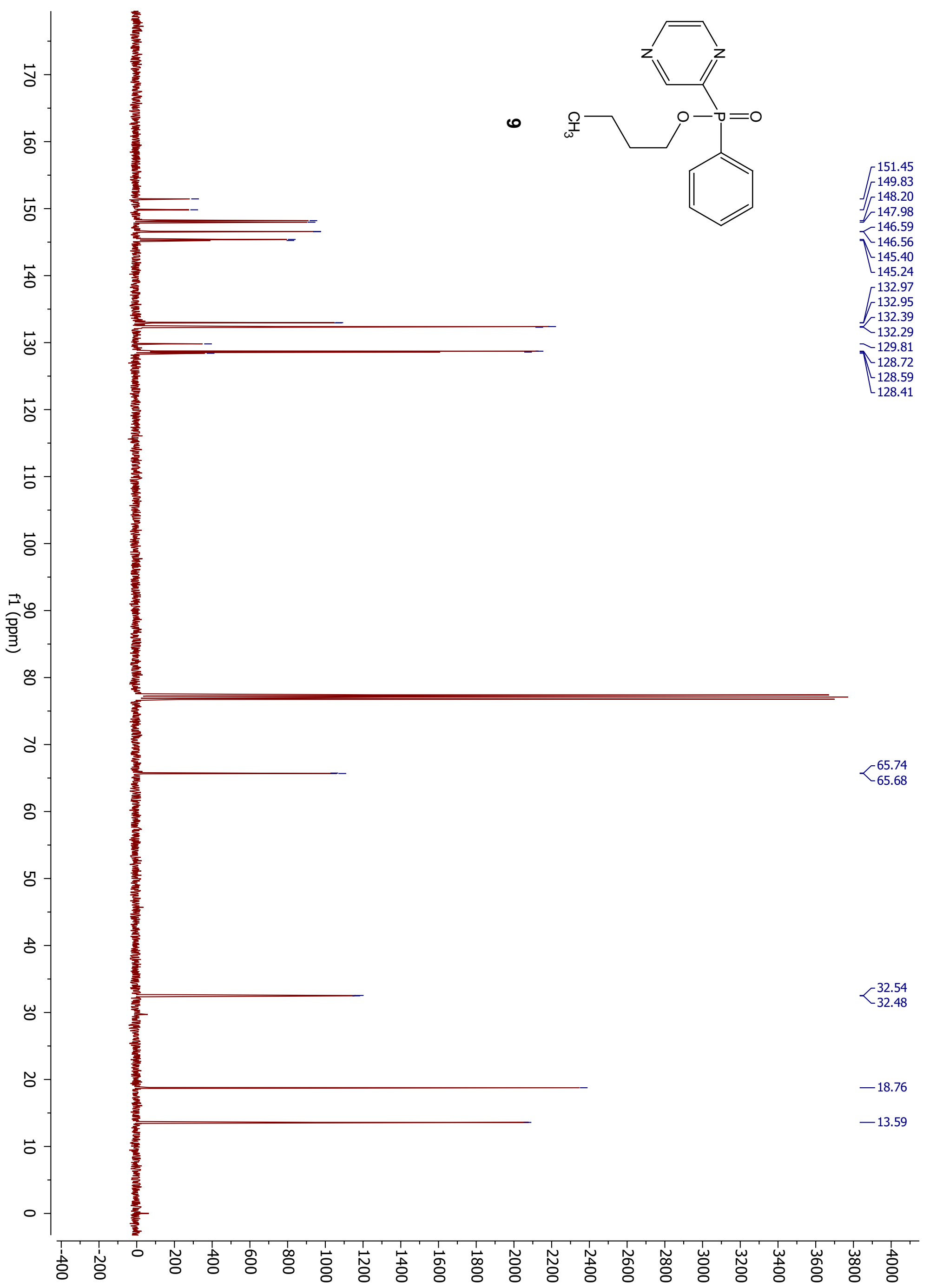




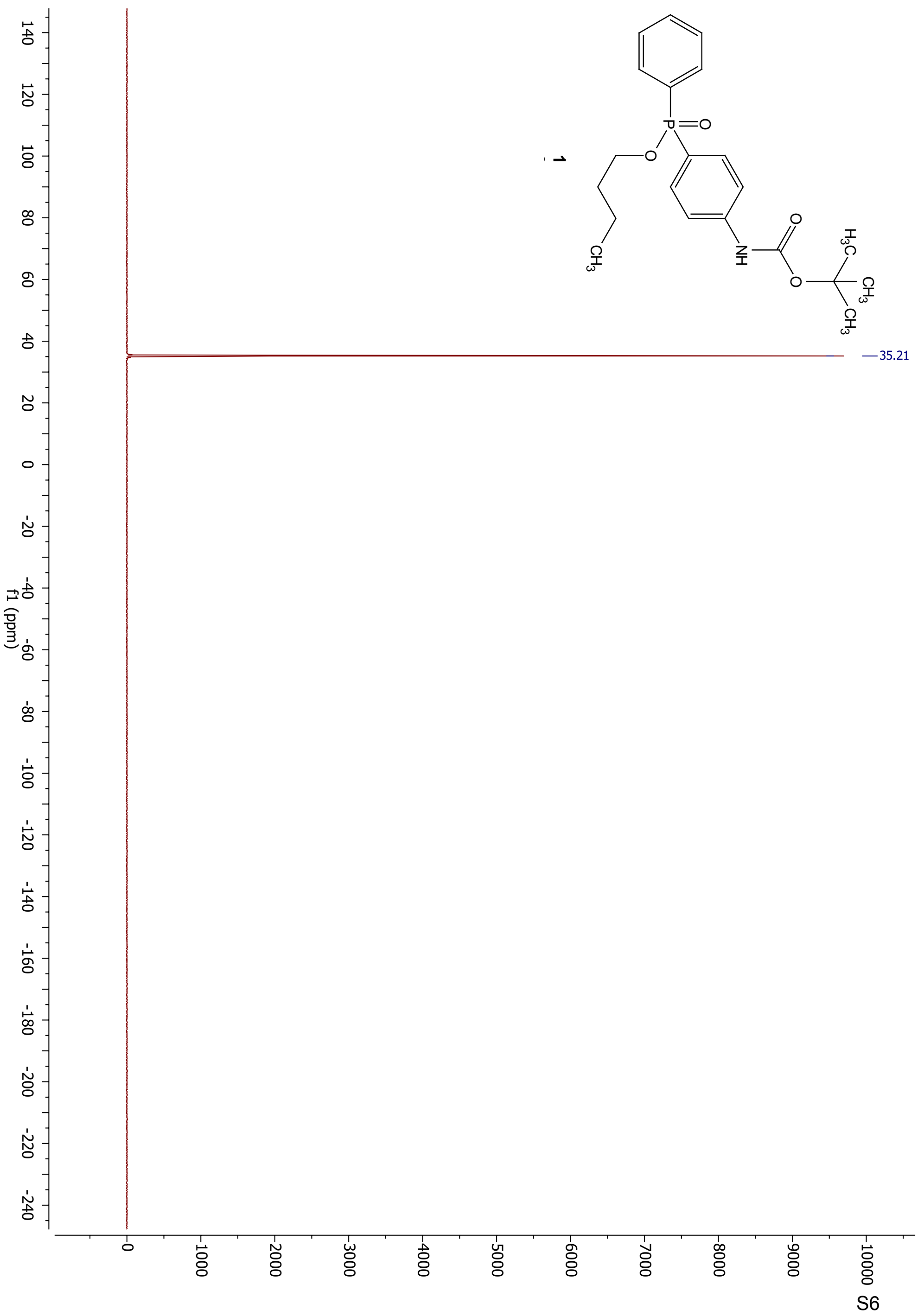




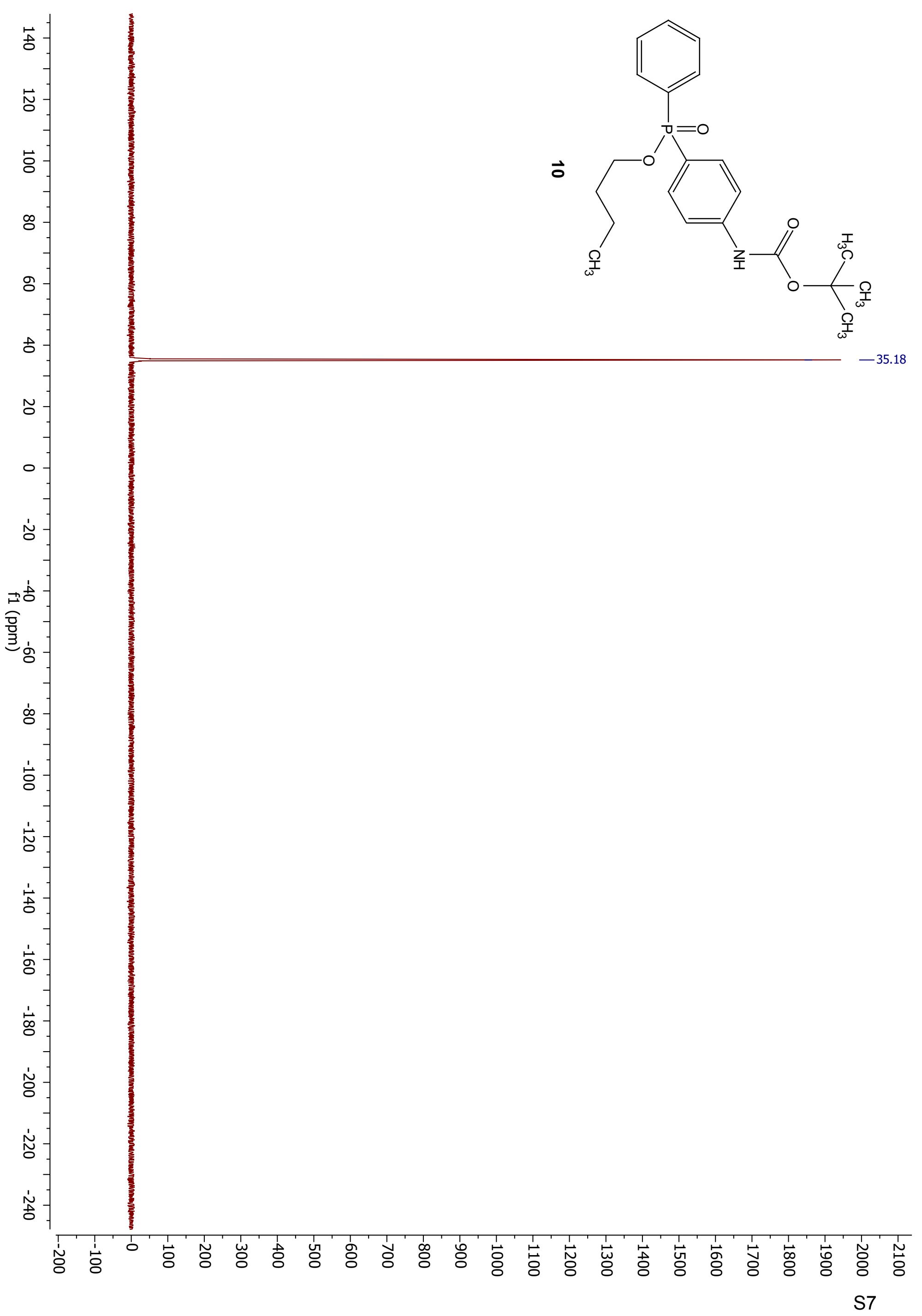




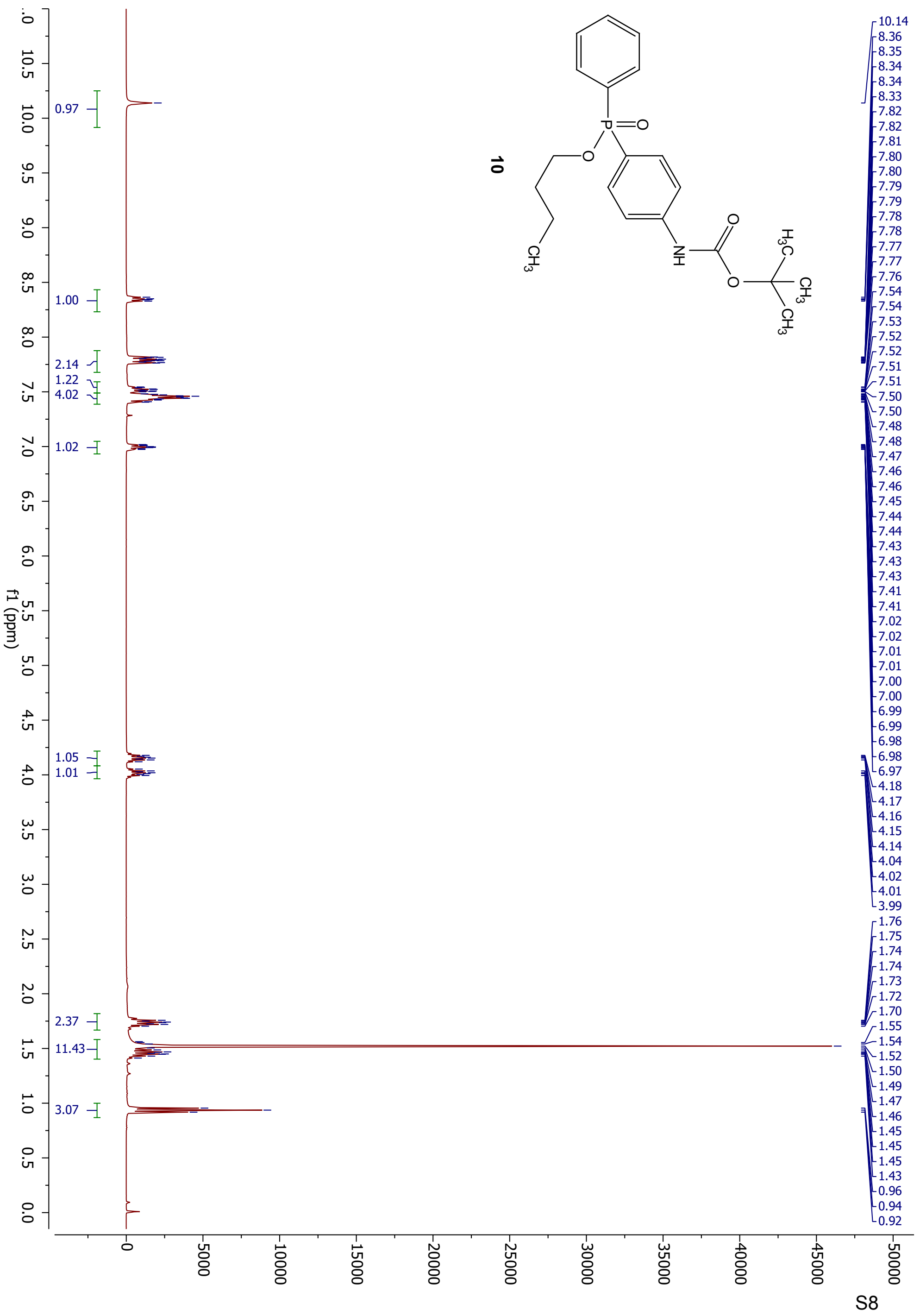




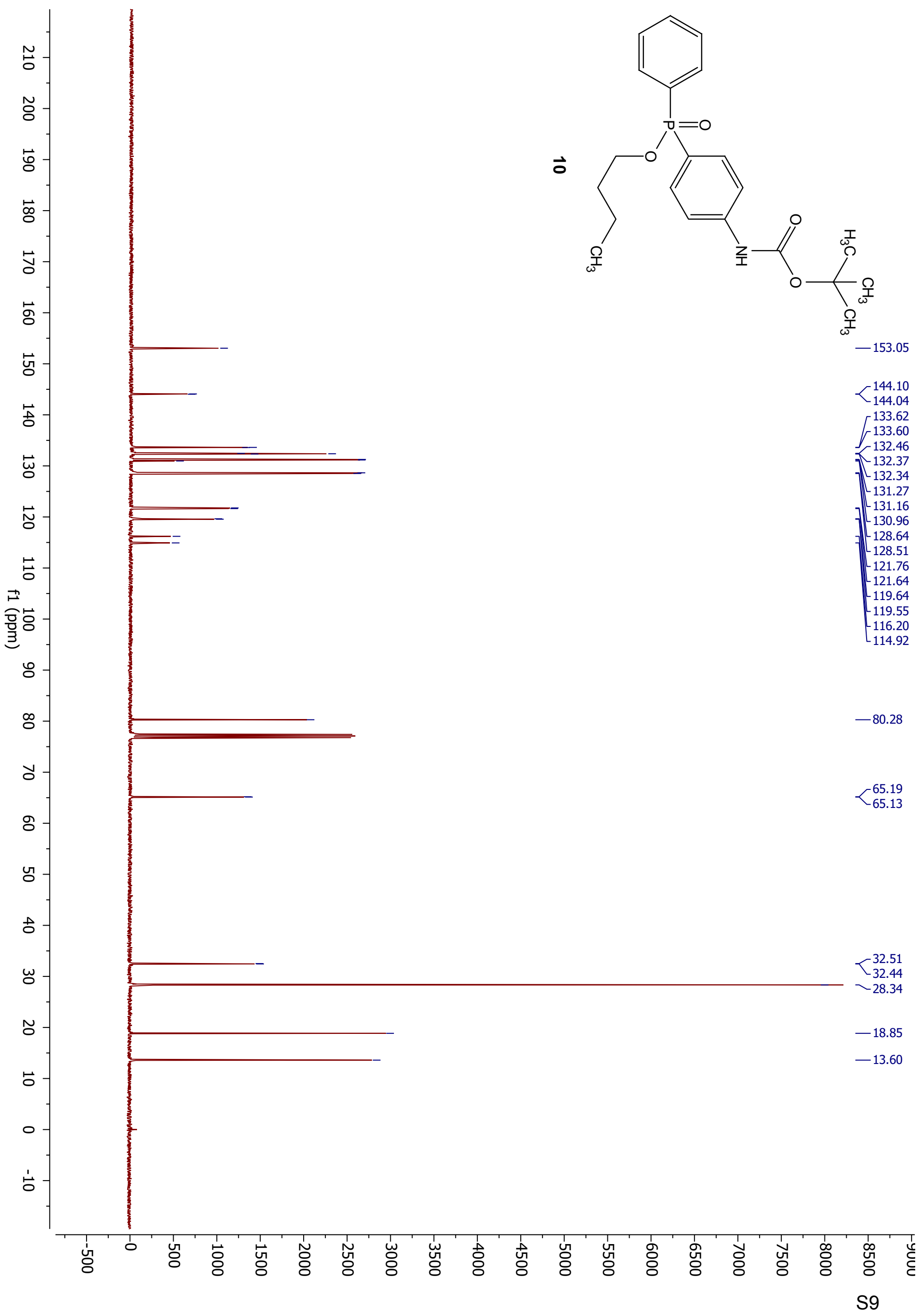




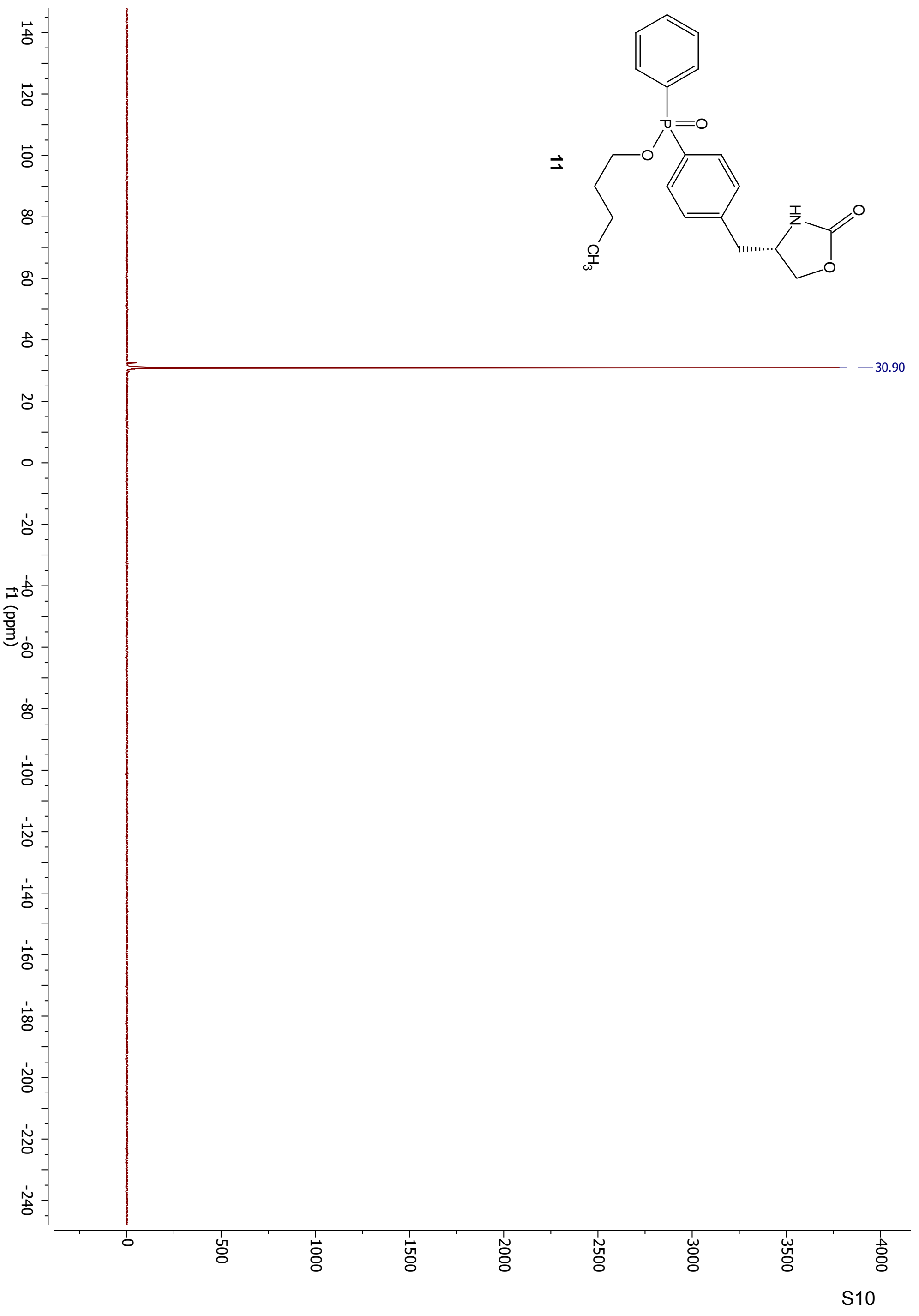




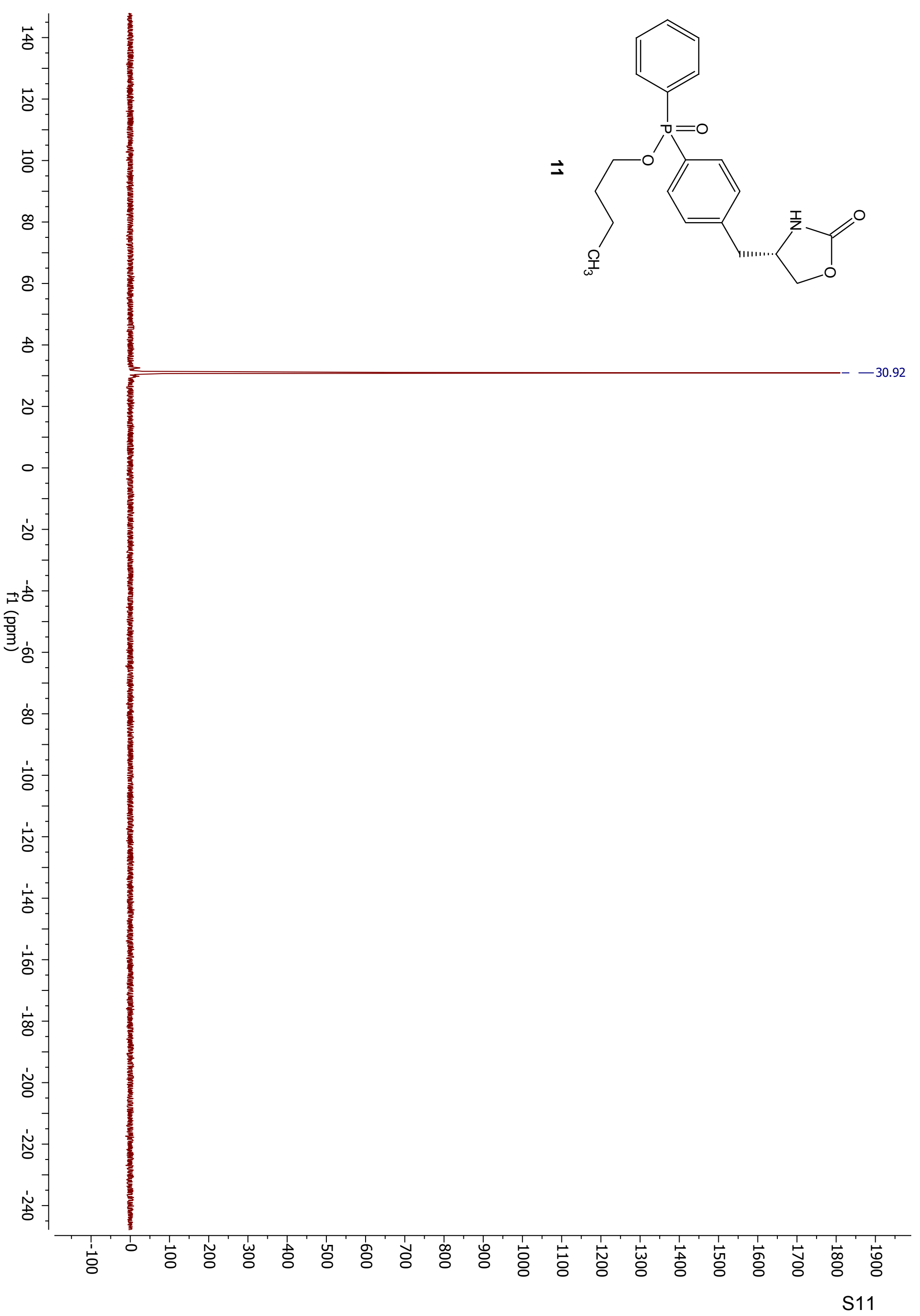




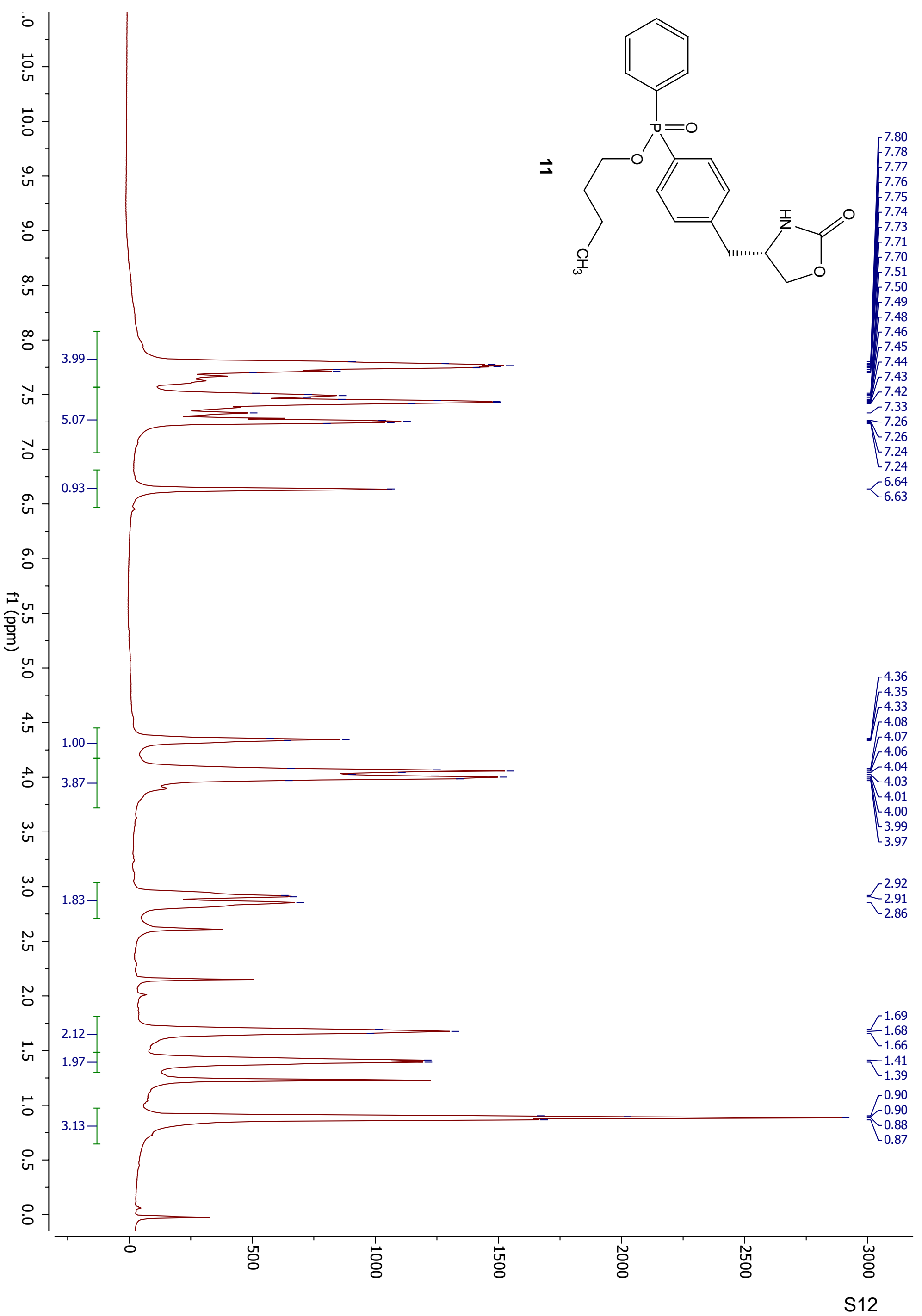



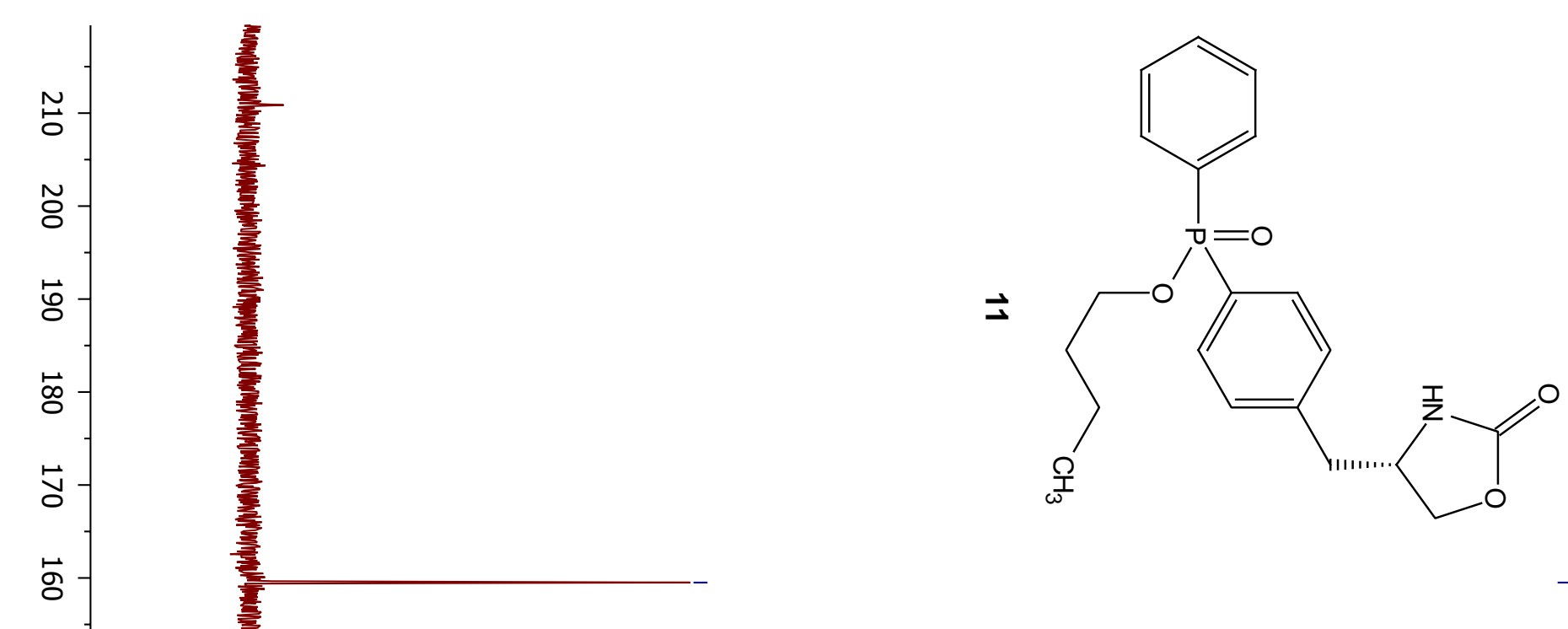

$-159.51$

140.54 140.51

133.06

133.02

132.31

132.28

$-132.22$

$-132.19$

$-132.12$

132.05

131.93

$-131.70$

131.65

$-131.55$

$-131.22$

$-129.85$

129.42

$-129.29$

129.17

$-129.04$

128.70

$-128.65$

128.57

128.52

77.49

77.49
-77.17

77.17
-76.85

76.85

$\mathcal{L}_{69.25}^{69.16}$

64.96

64.90

64.85

64.79

$-53.43$

$-53.39$

ज

古

$-41.21$

40.98

32.57
32.50

$-32.50$

$-31.79$

$-18.84$

$-13.63$

\llcorner

$\widetilde{\sigma}$

旁

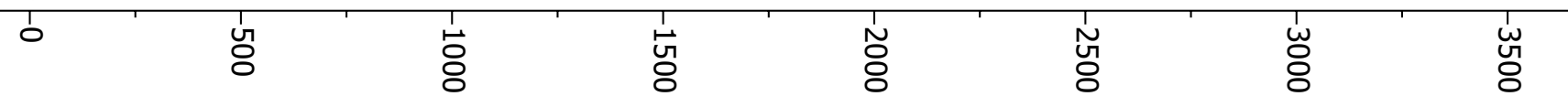




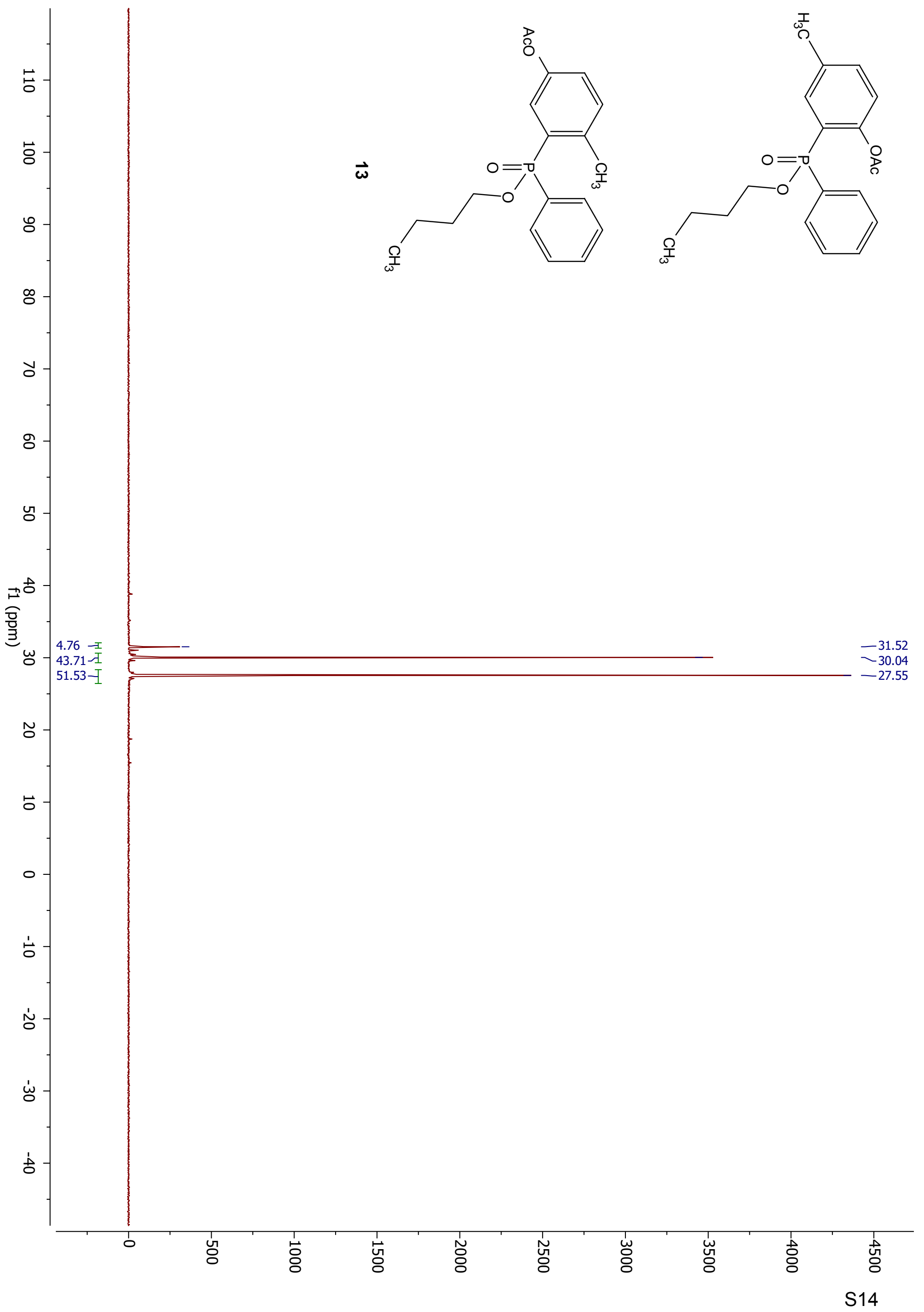




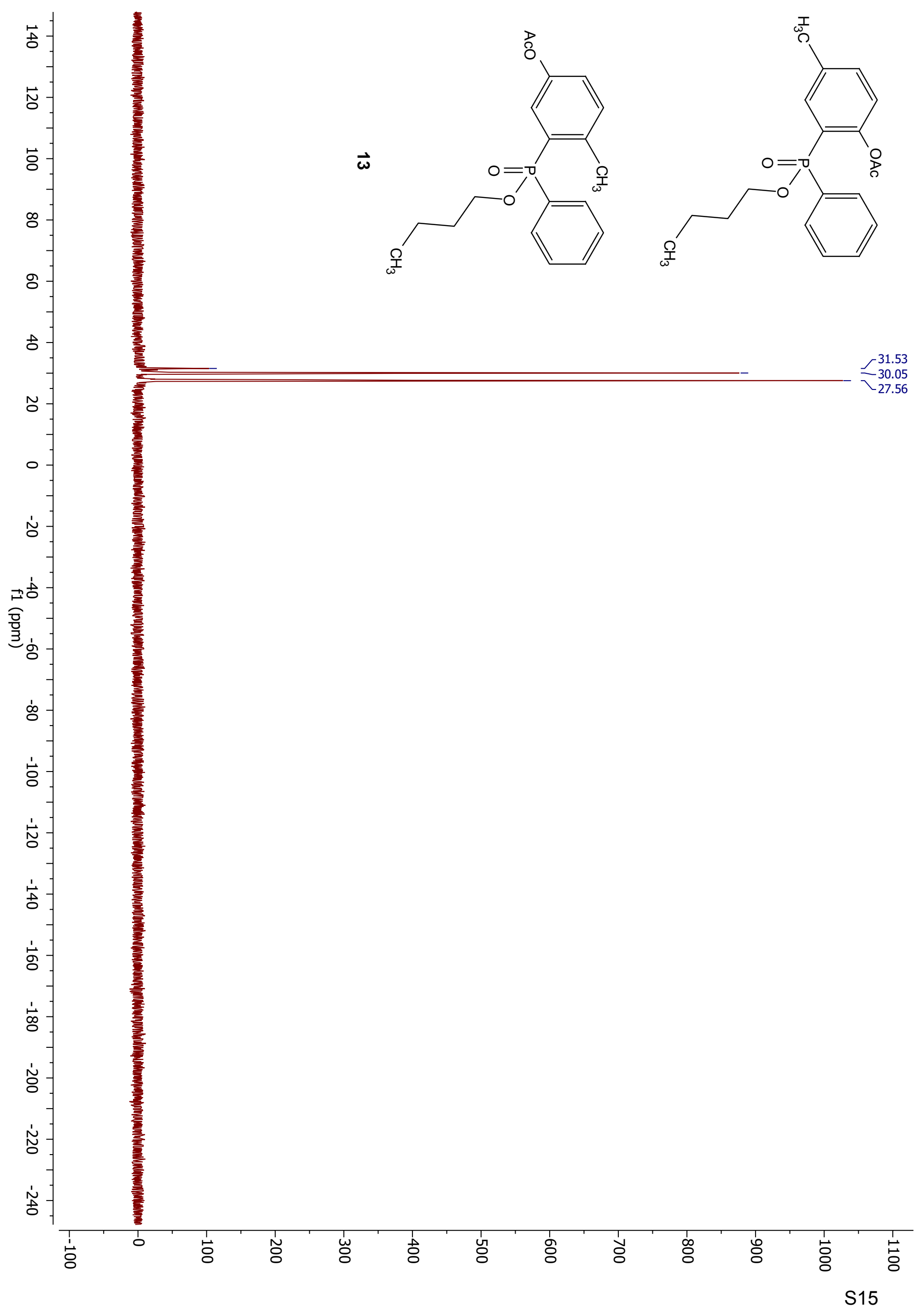




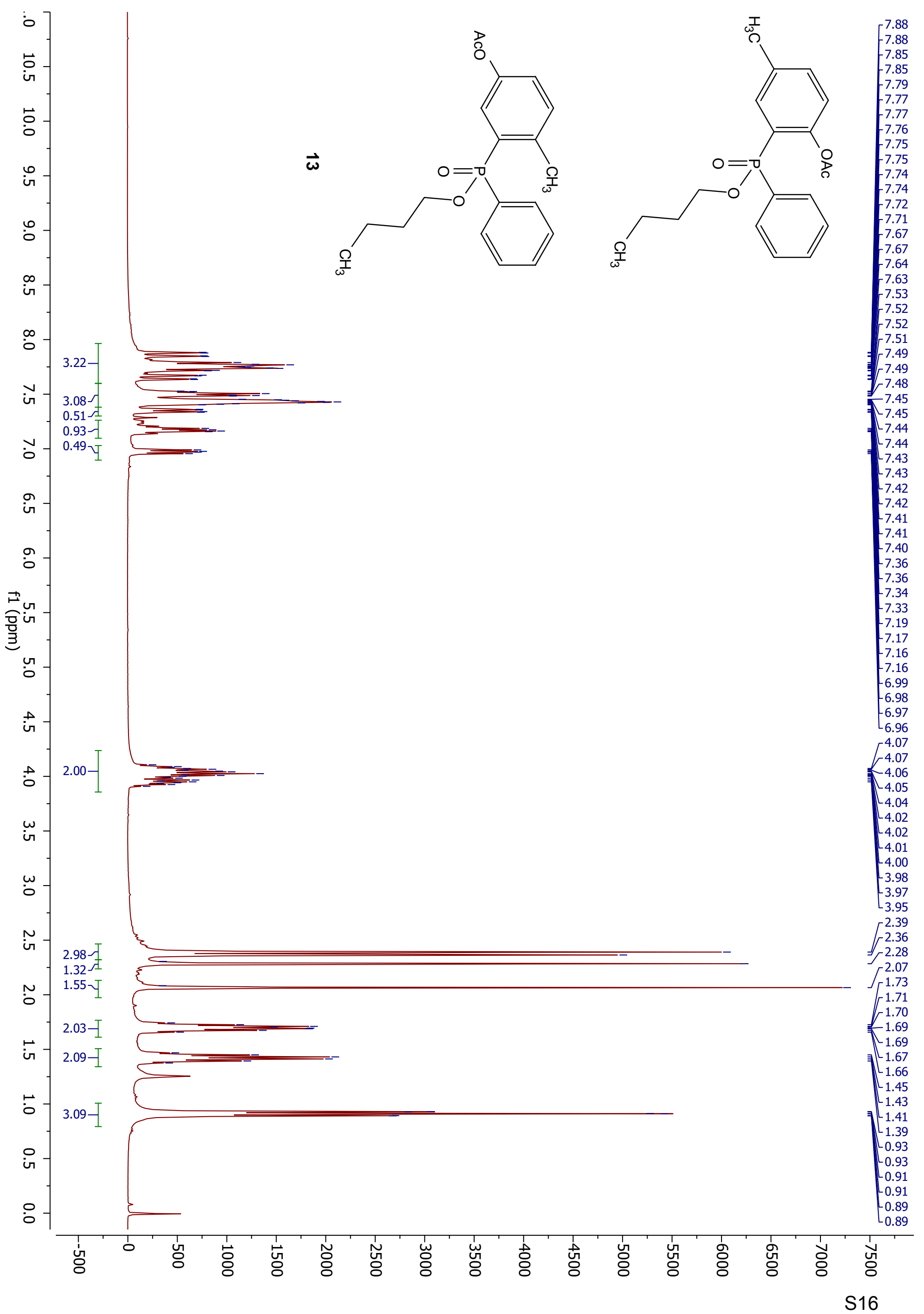




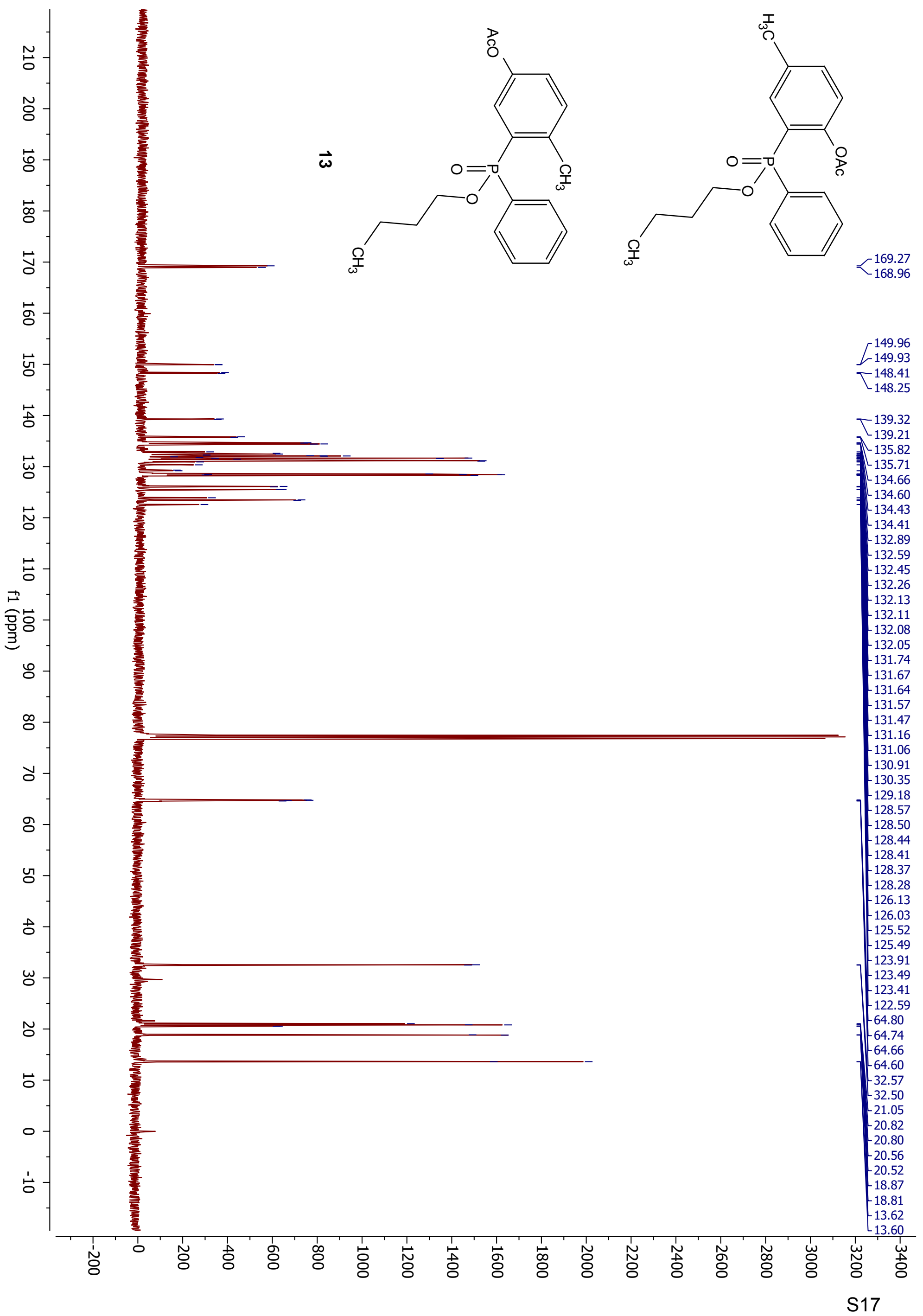




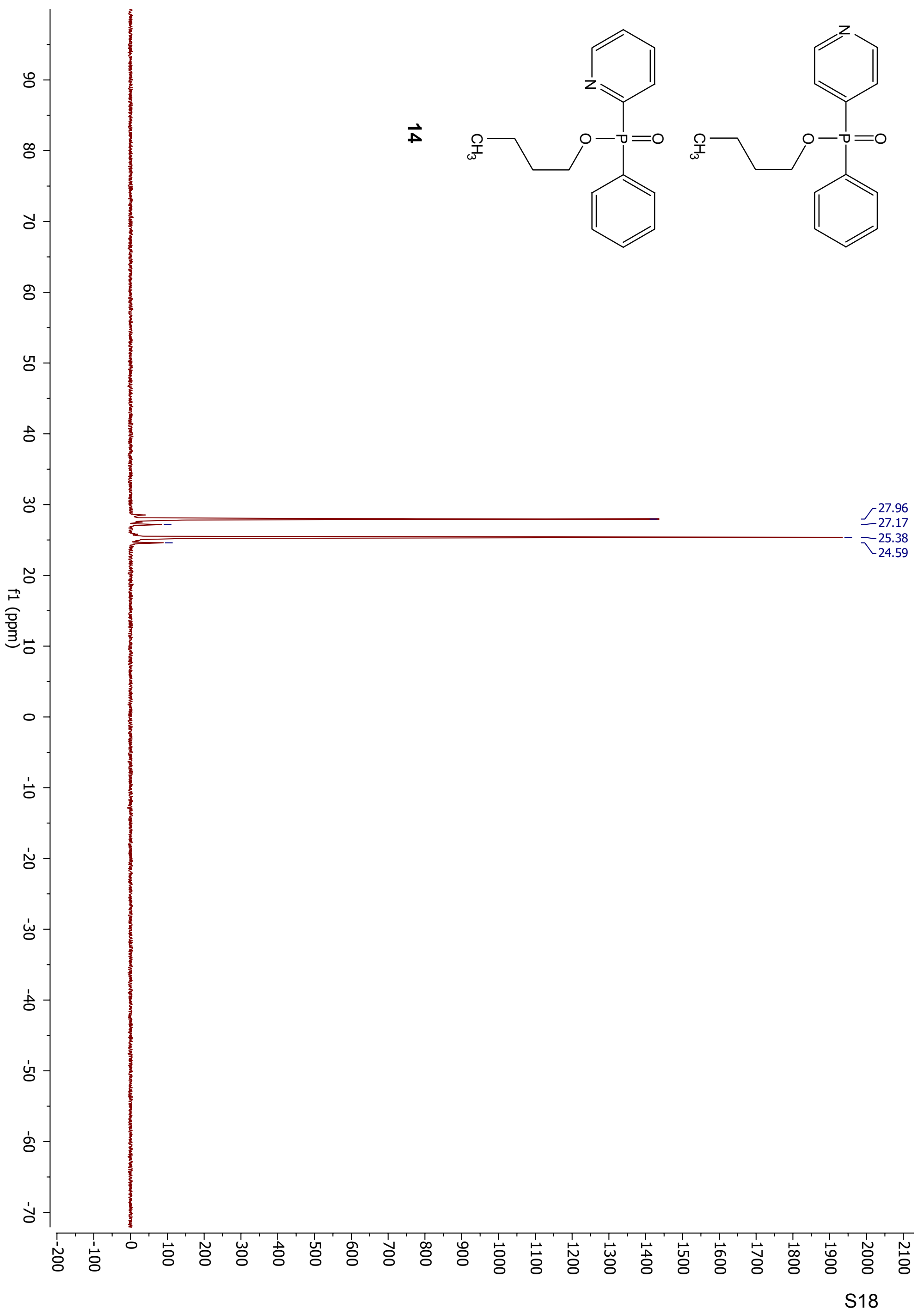




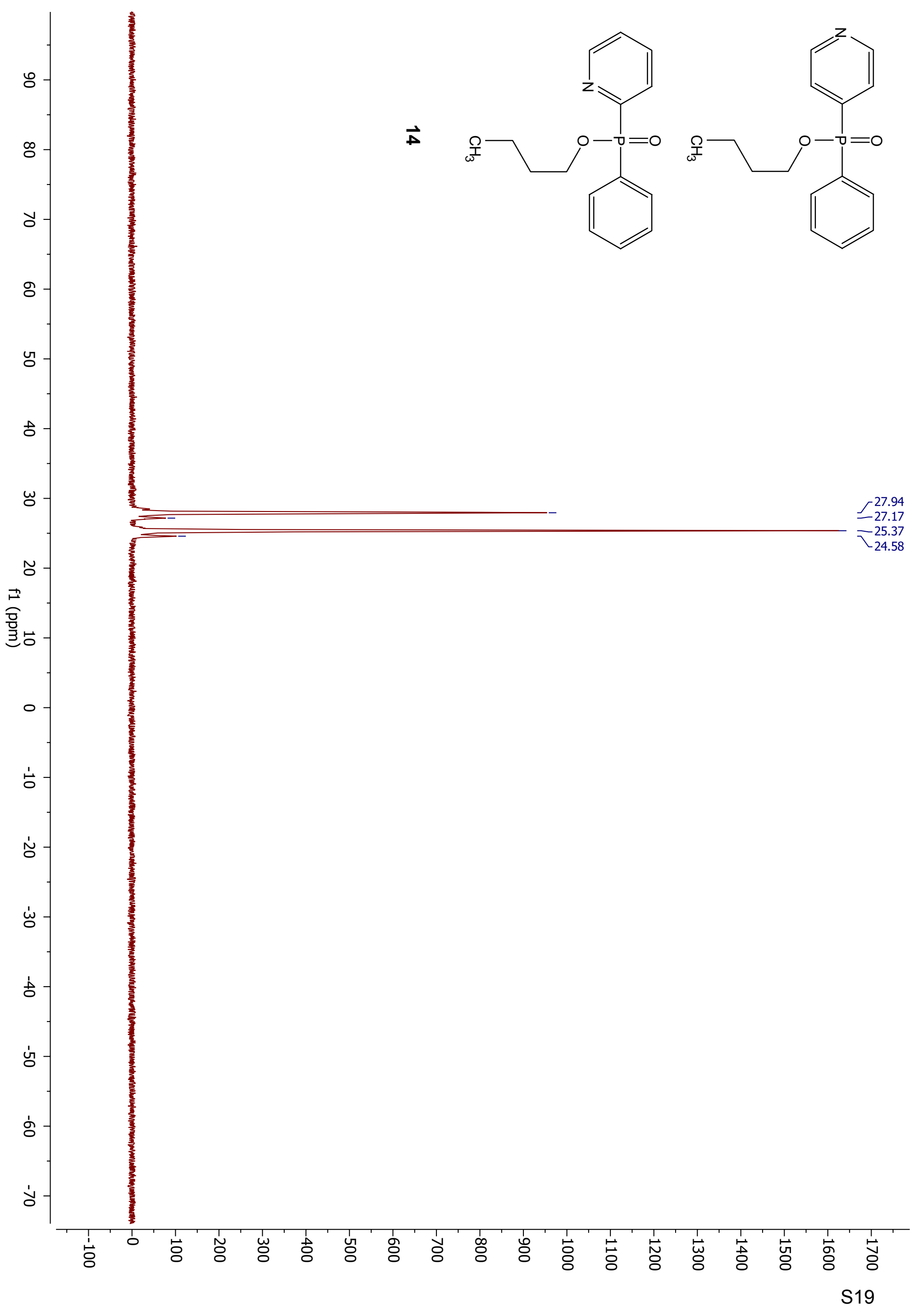




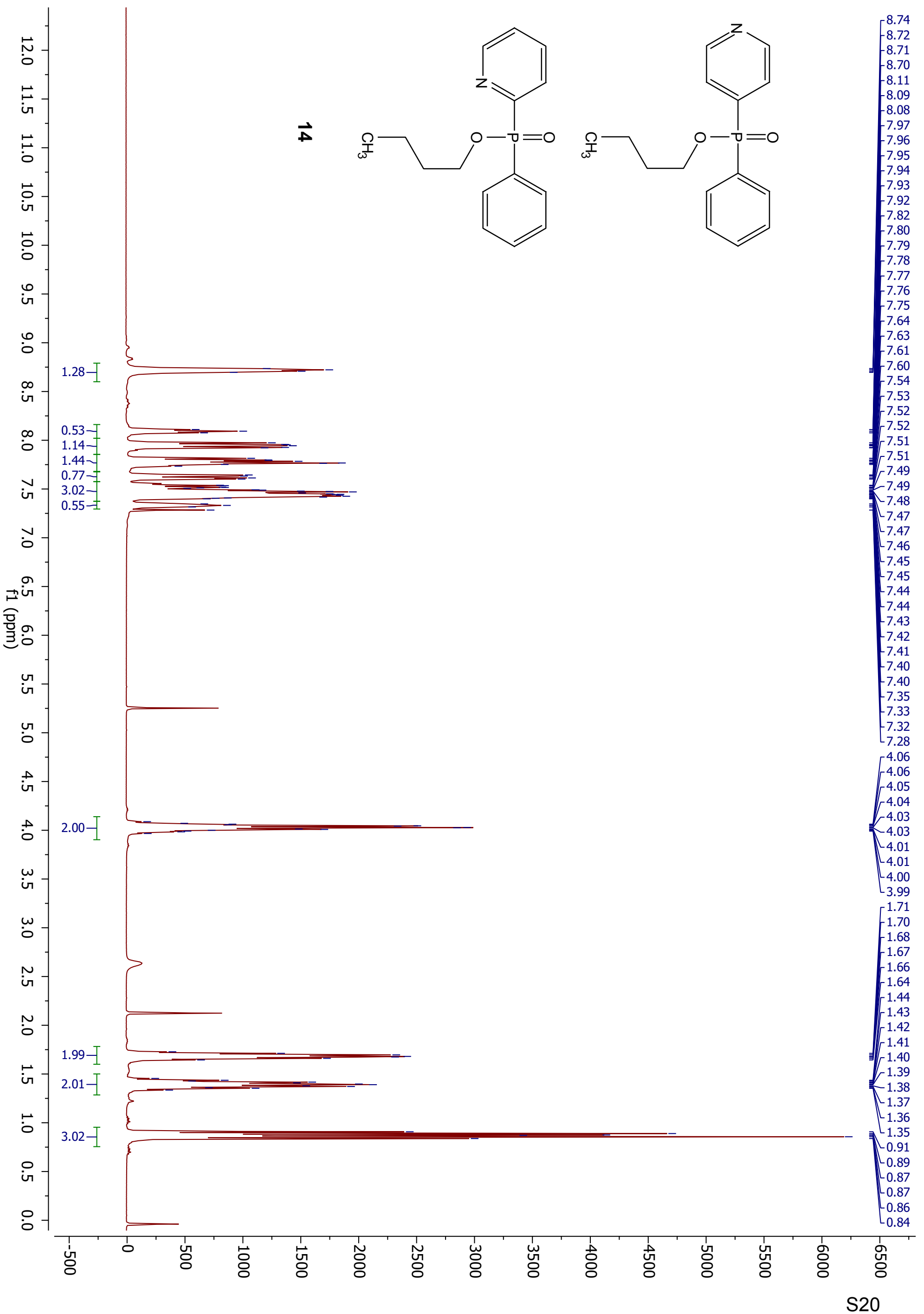




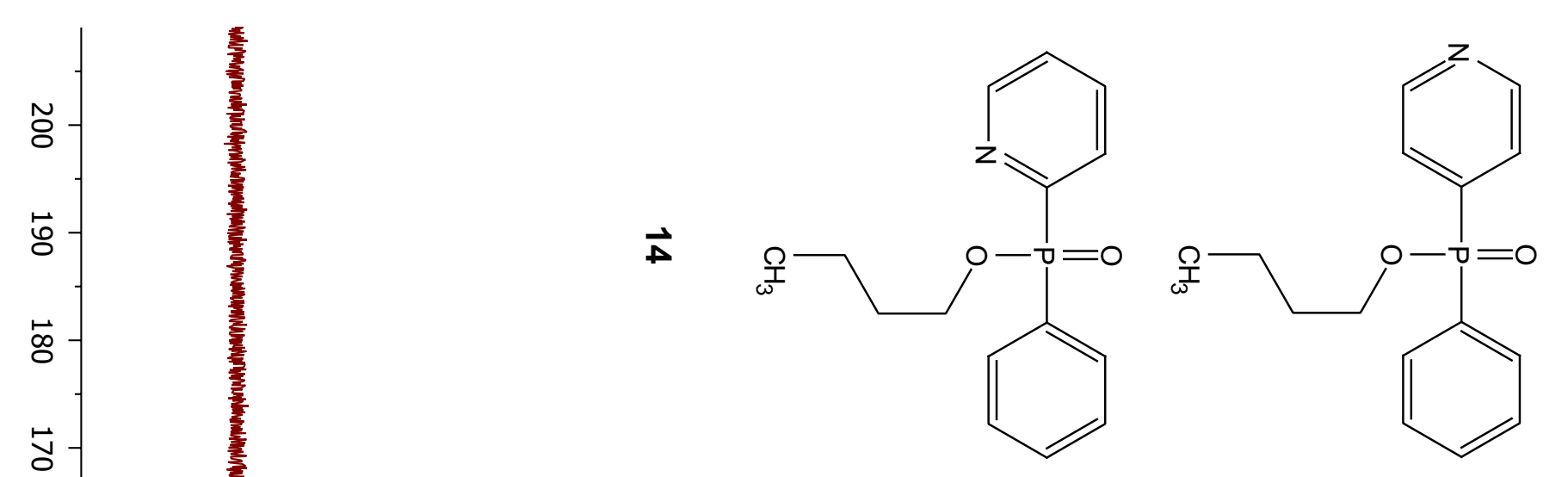

155.59

153.92

150.64

$-150.44$

150.12

150.01

141.53

140.22

136.06

135.96

132.82

$-132.80$

132.38

132.35

132.30

132.20

131.79

131.69

130.88

130.64

129.50

$-129.26$

$-128.88$

$-128.74$

$-128.42$

$-128.29$

128.25

128.03

$-125.62$

125.59

$-125.14$

$\infty$

125.05

65.30

65.24

8

ง

웅

32.58

$-32.52$

$-18.80$

$-13.59$

เ

$\circ-1$

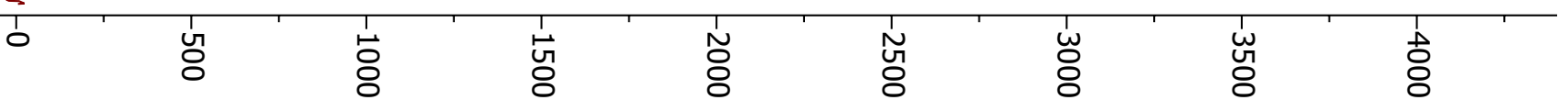




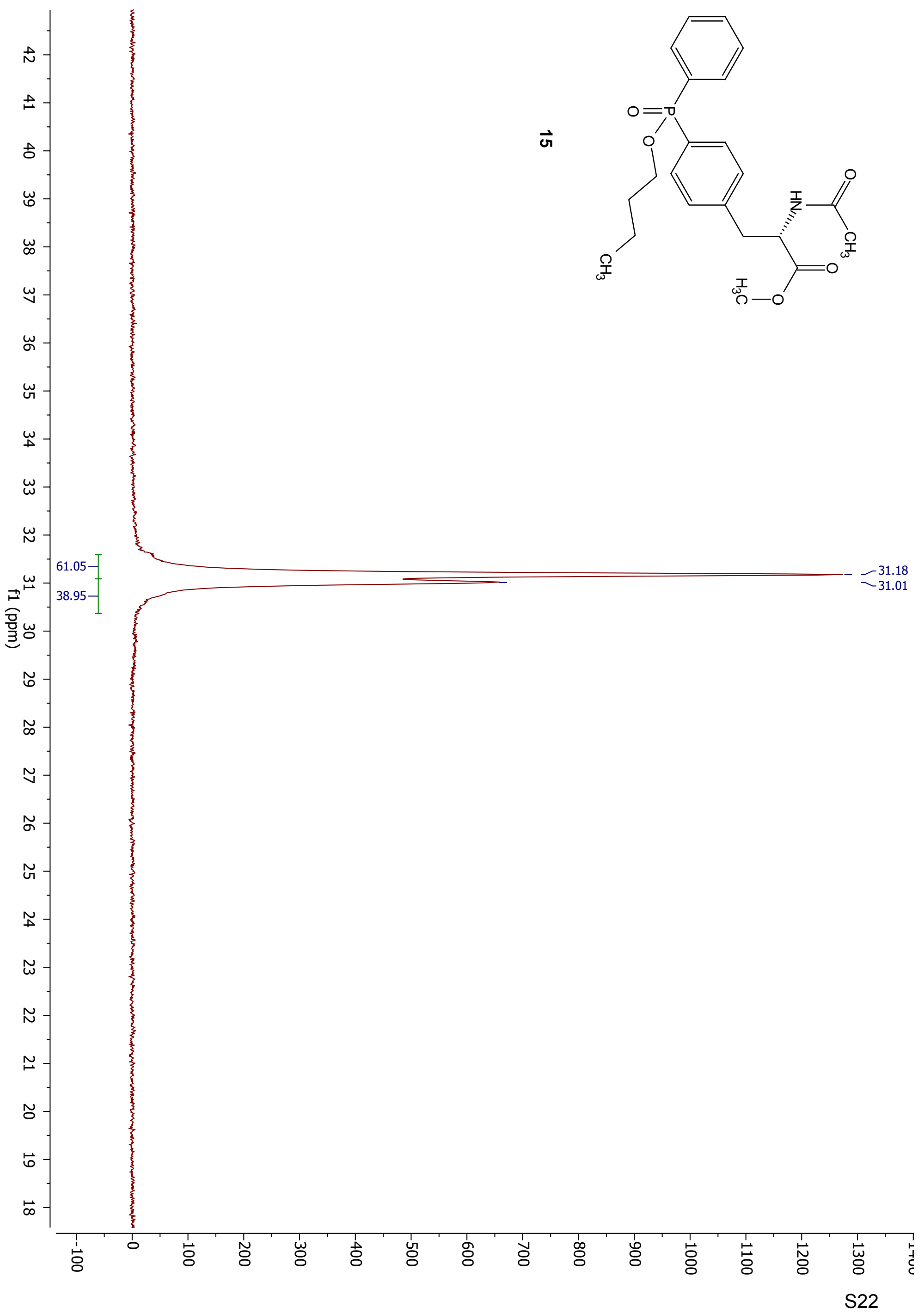




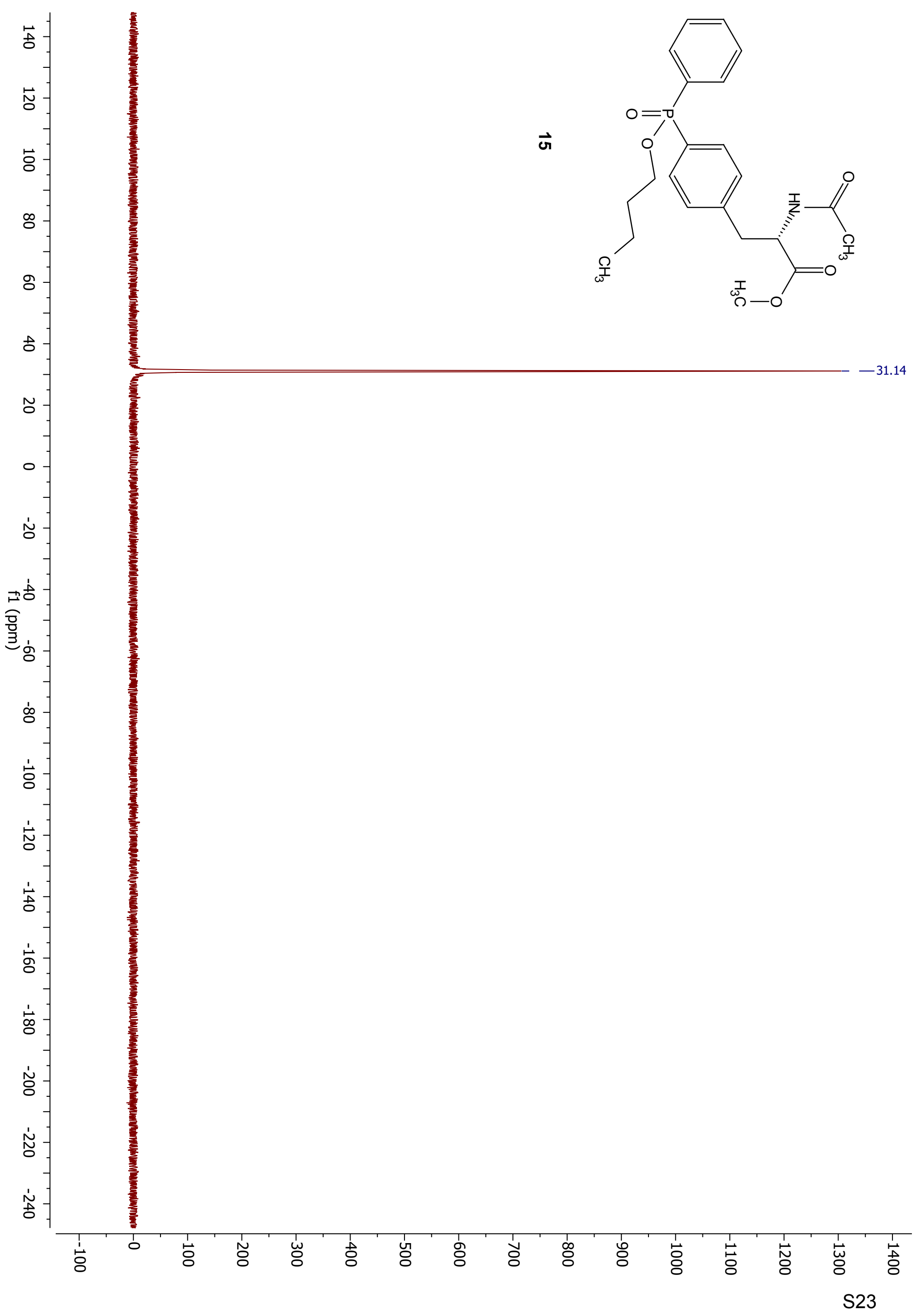




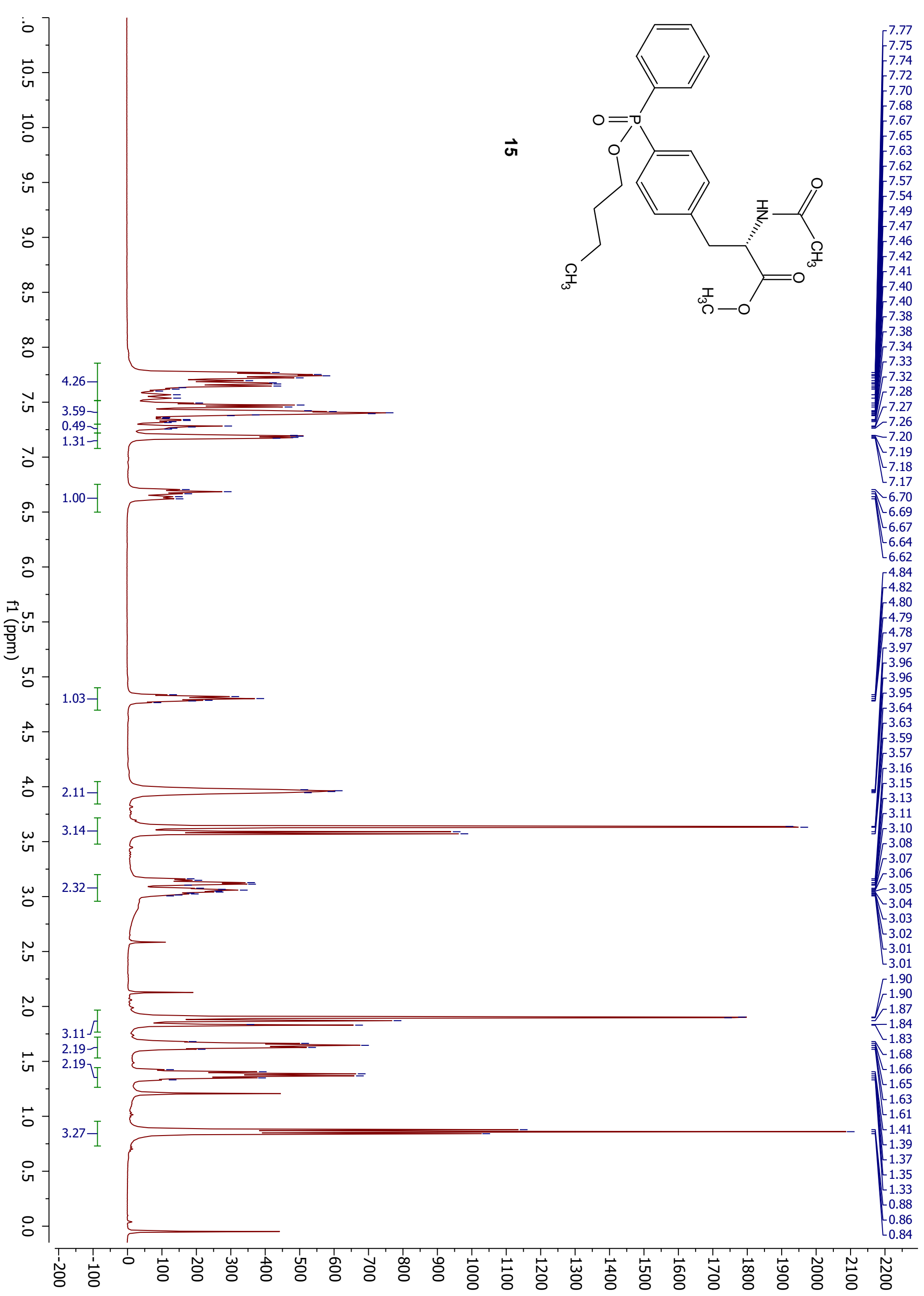




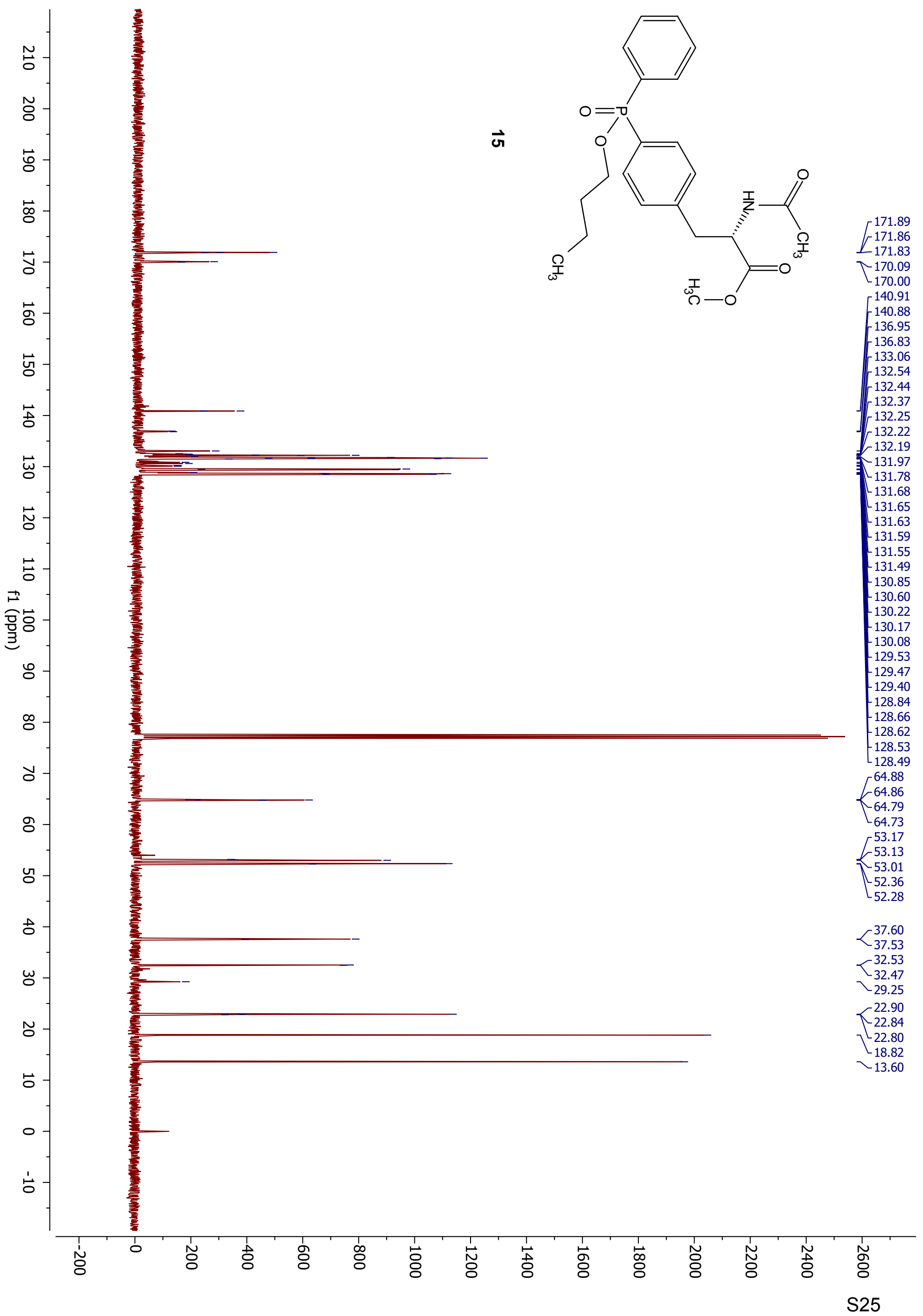




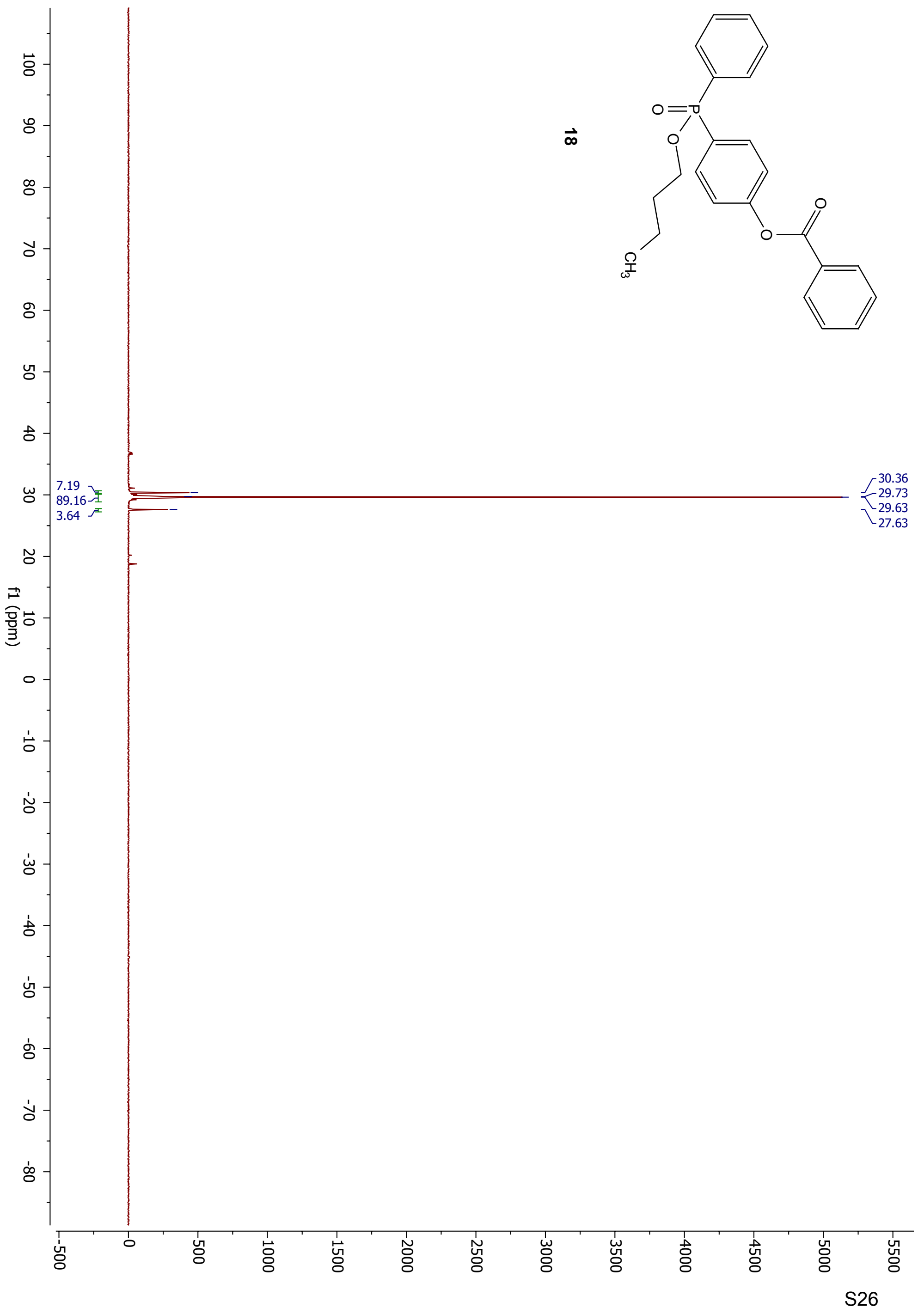




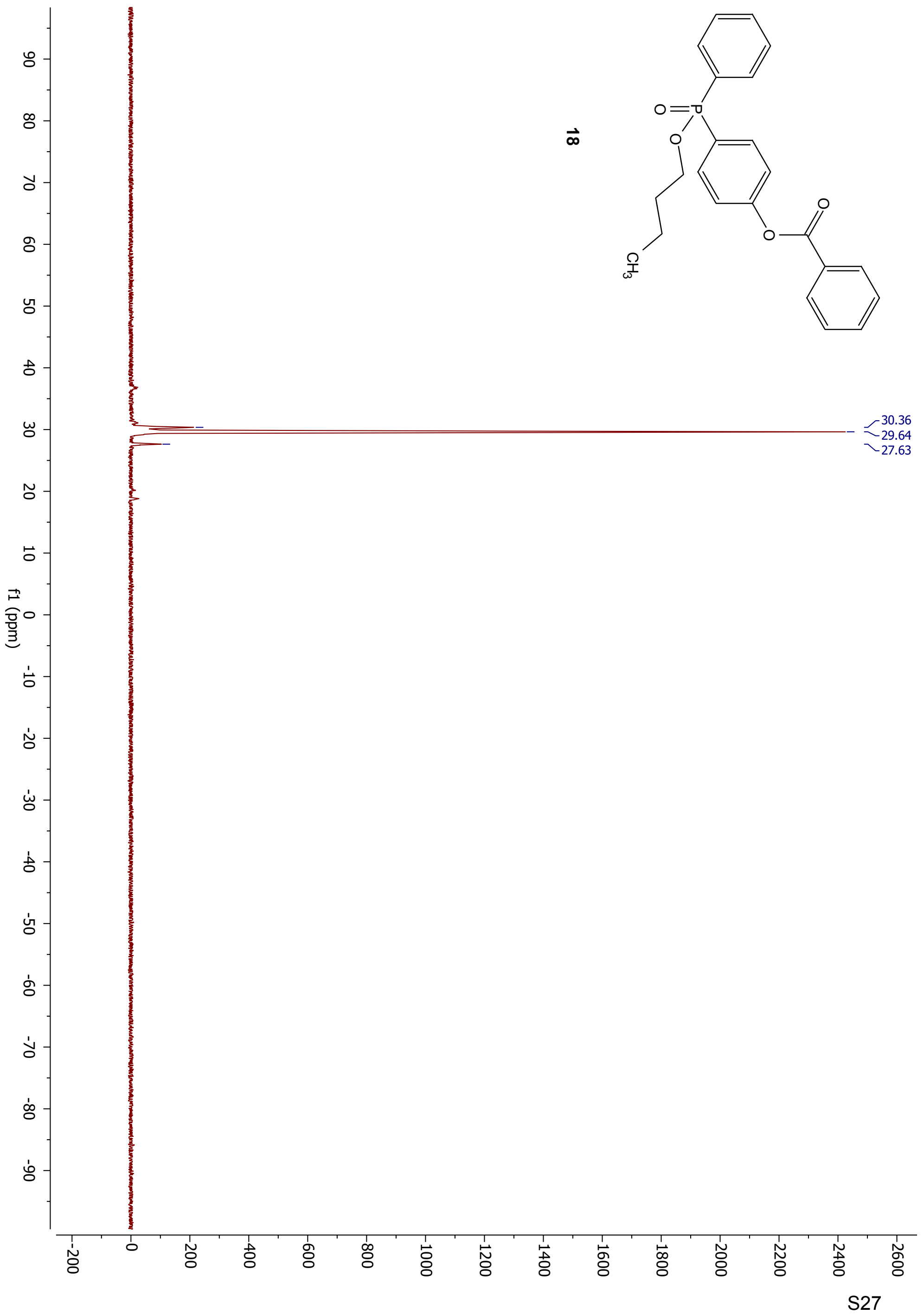




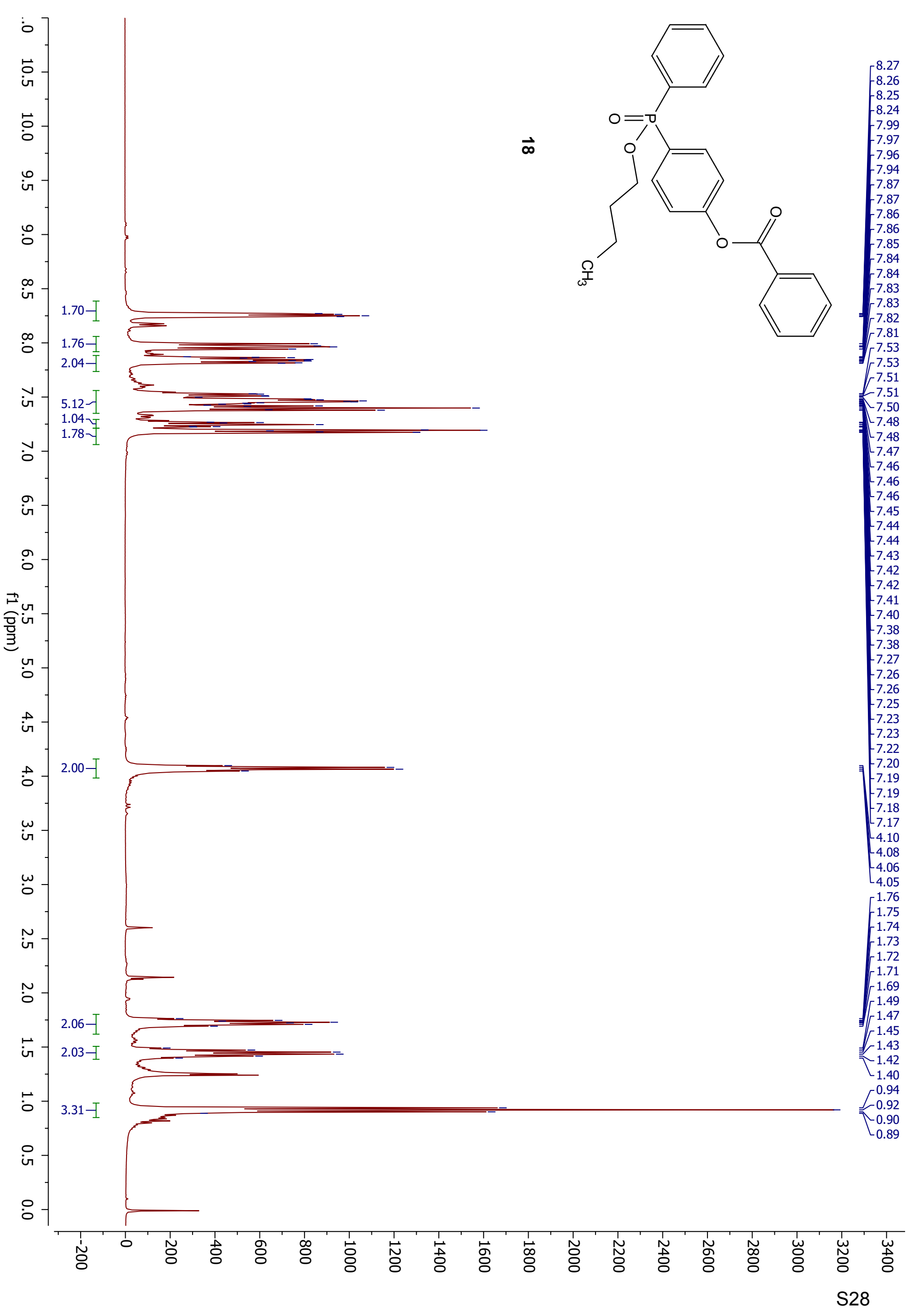




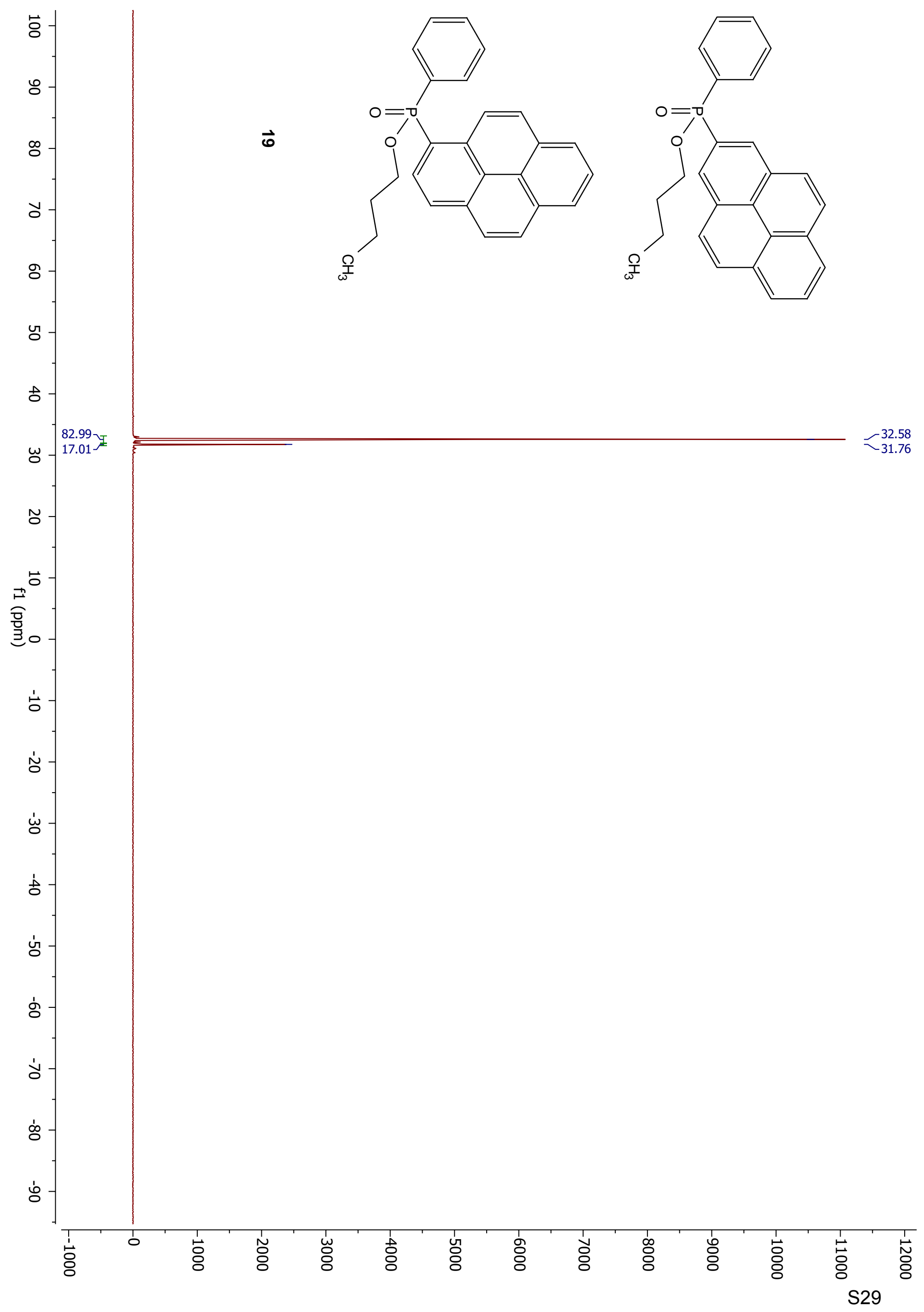




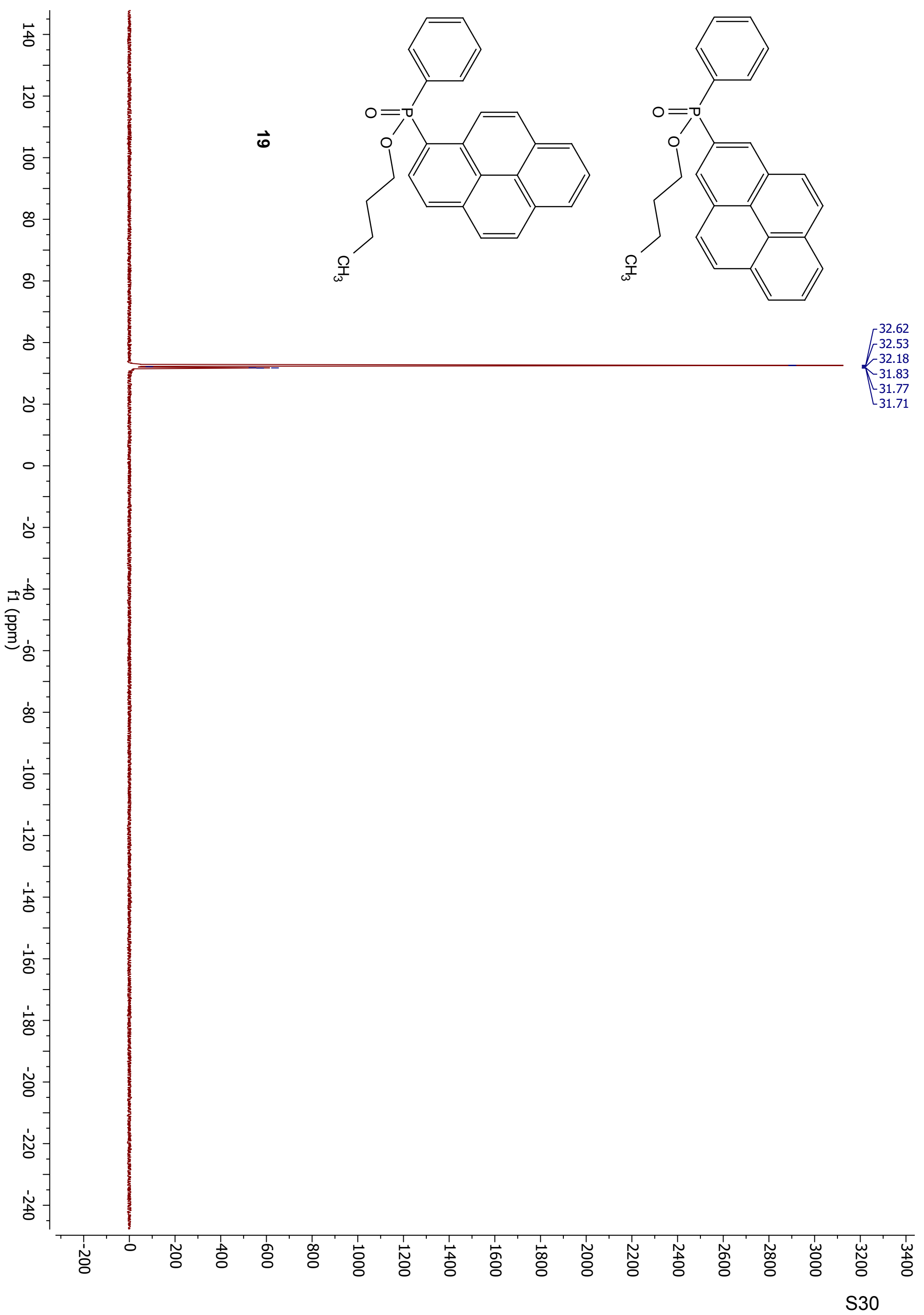




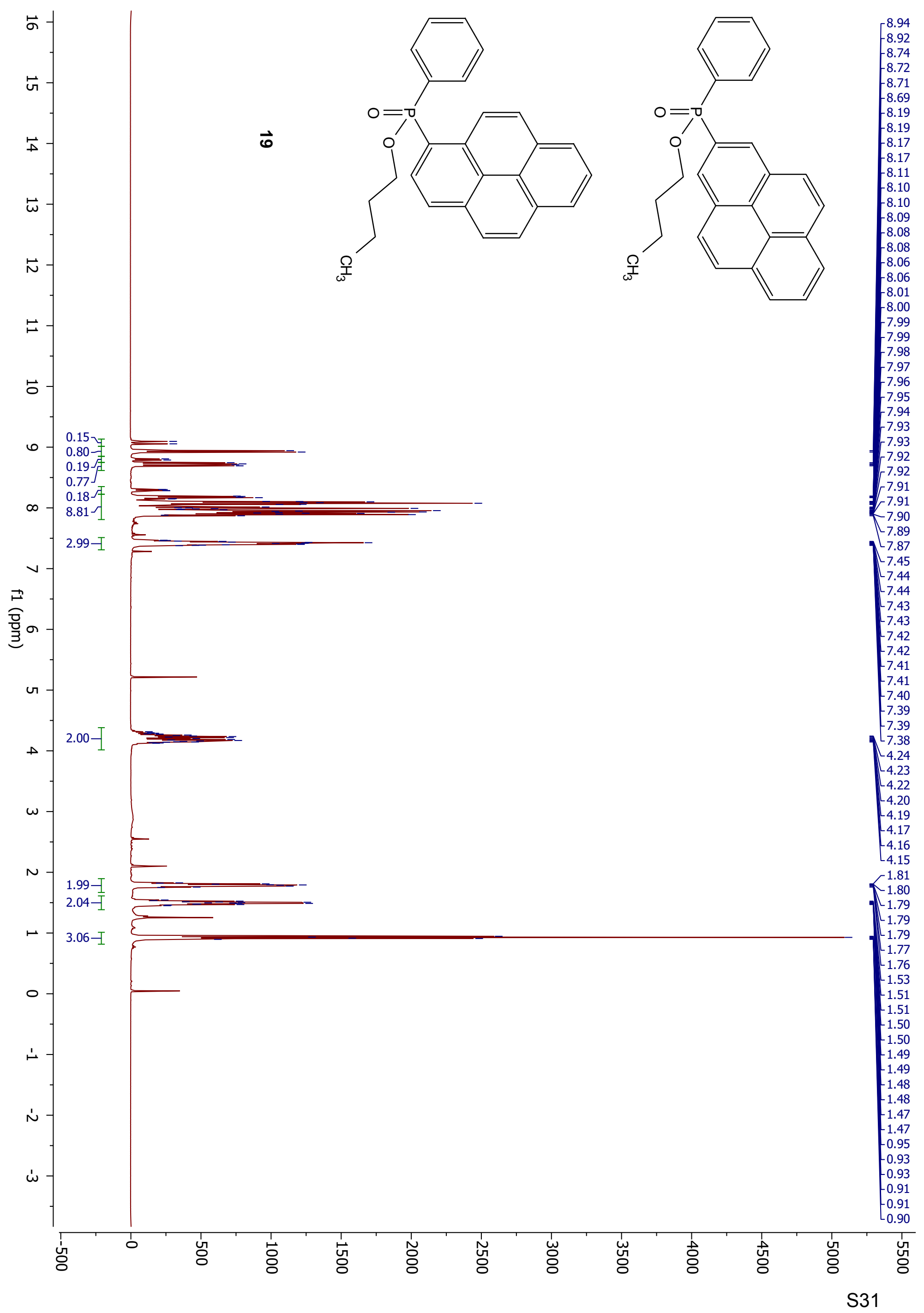




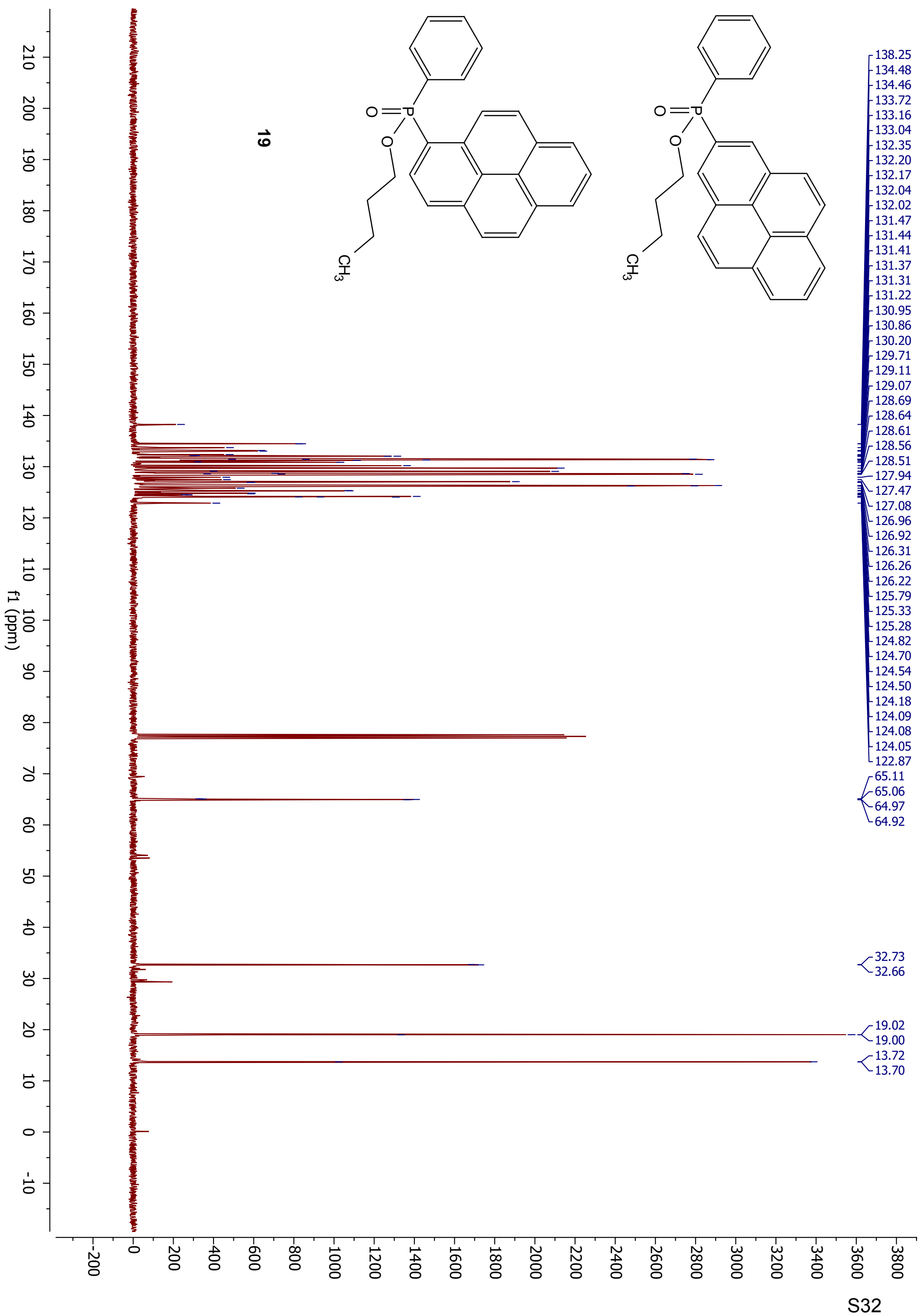




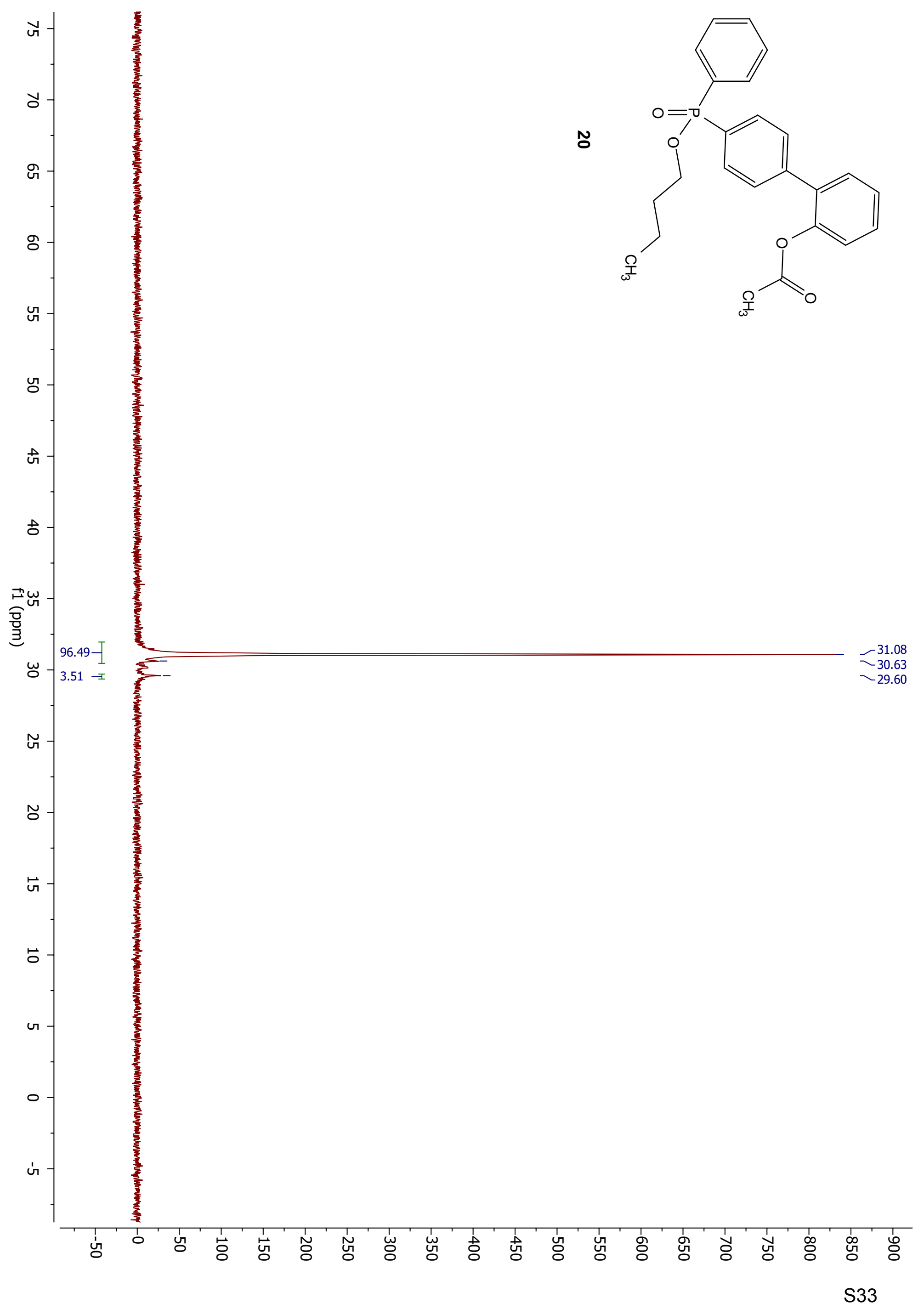




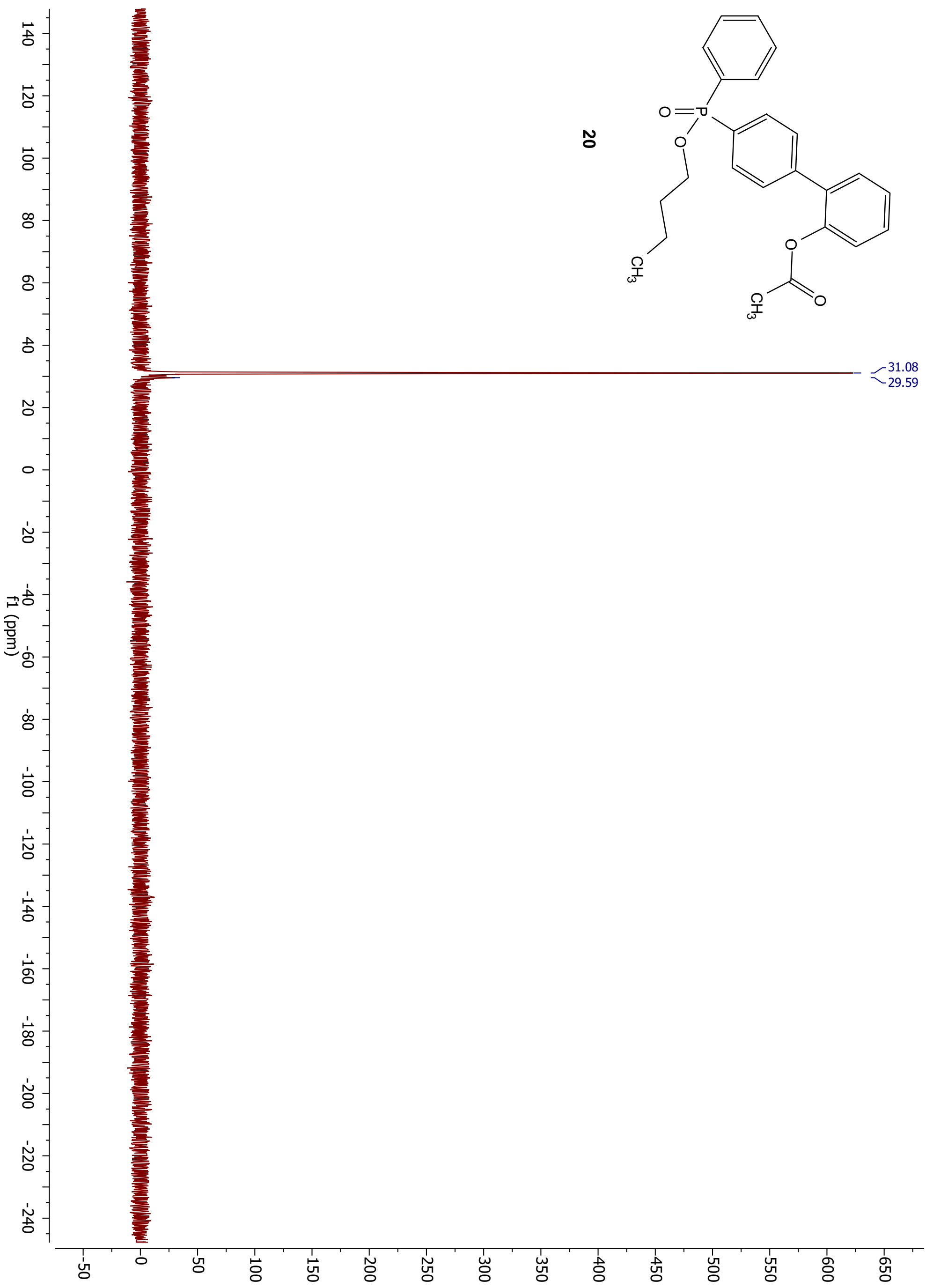




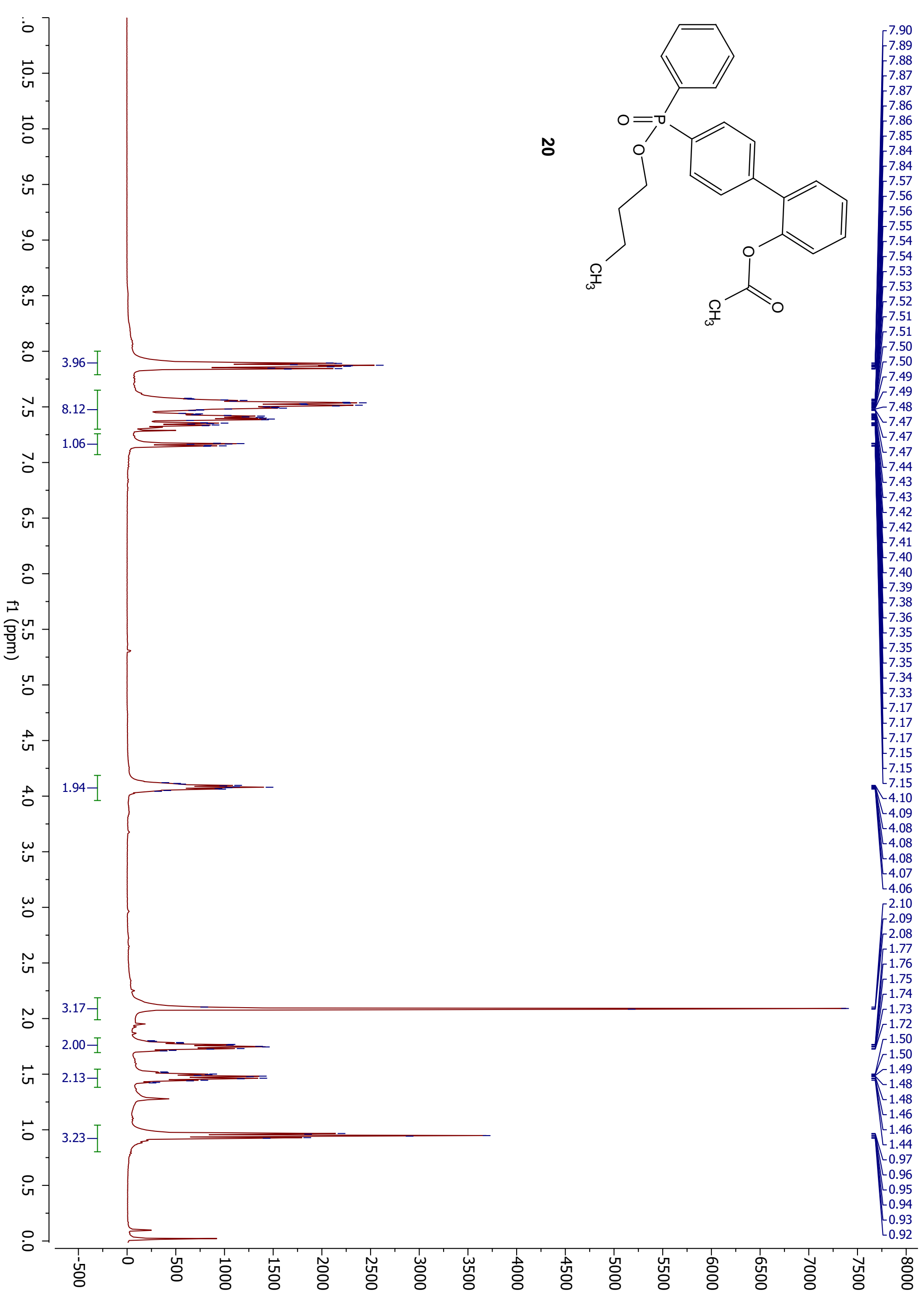




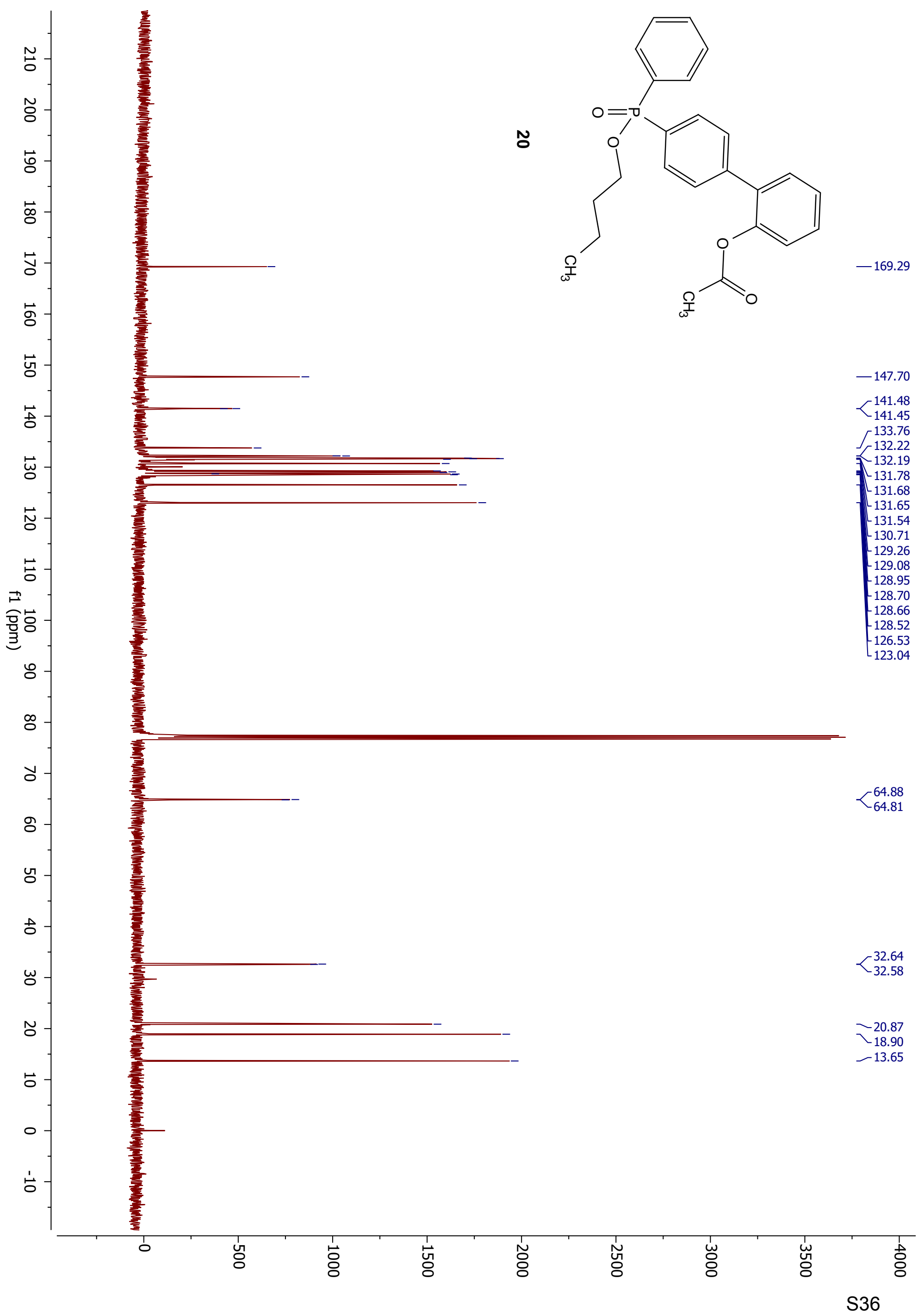




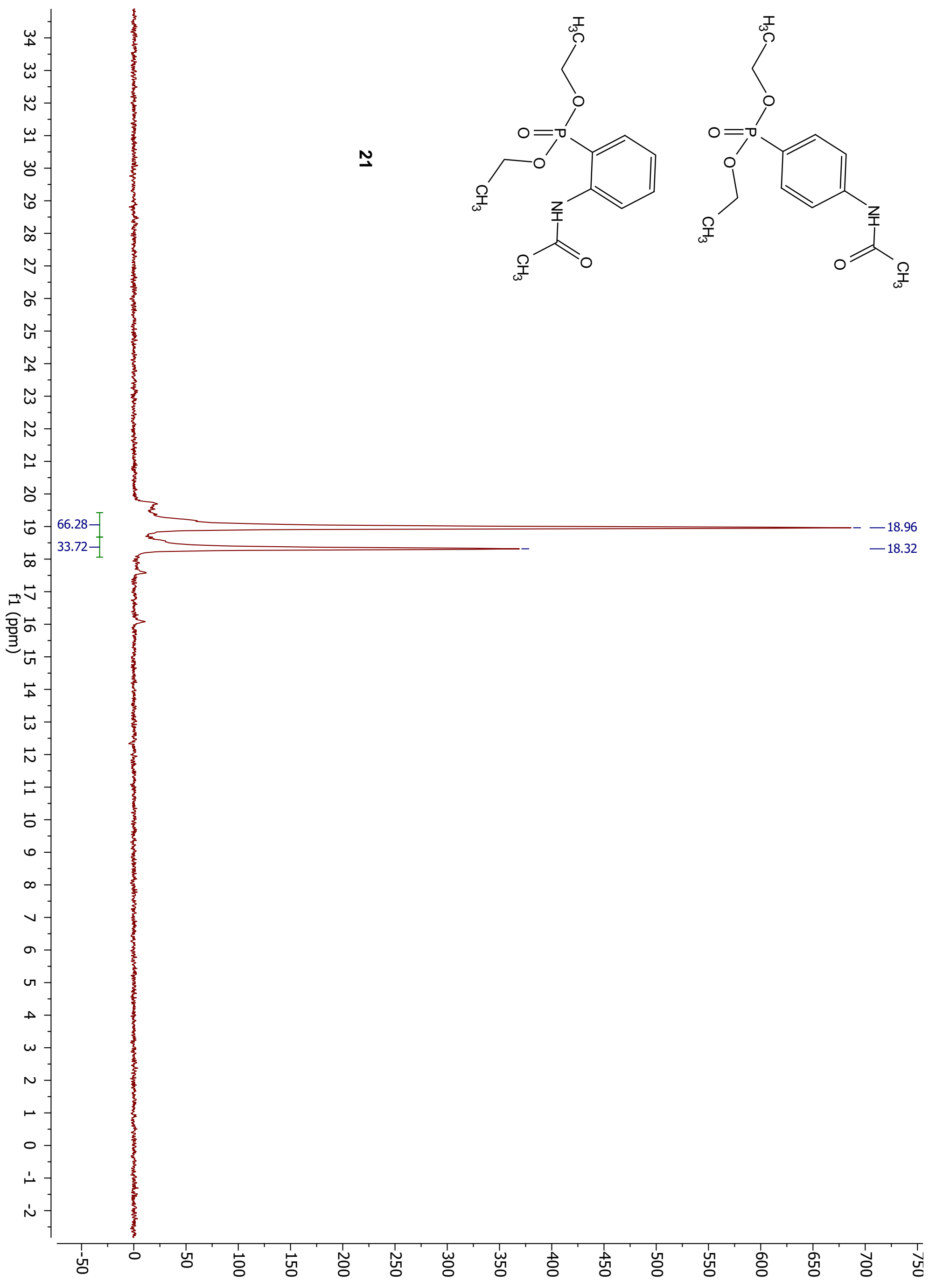




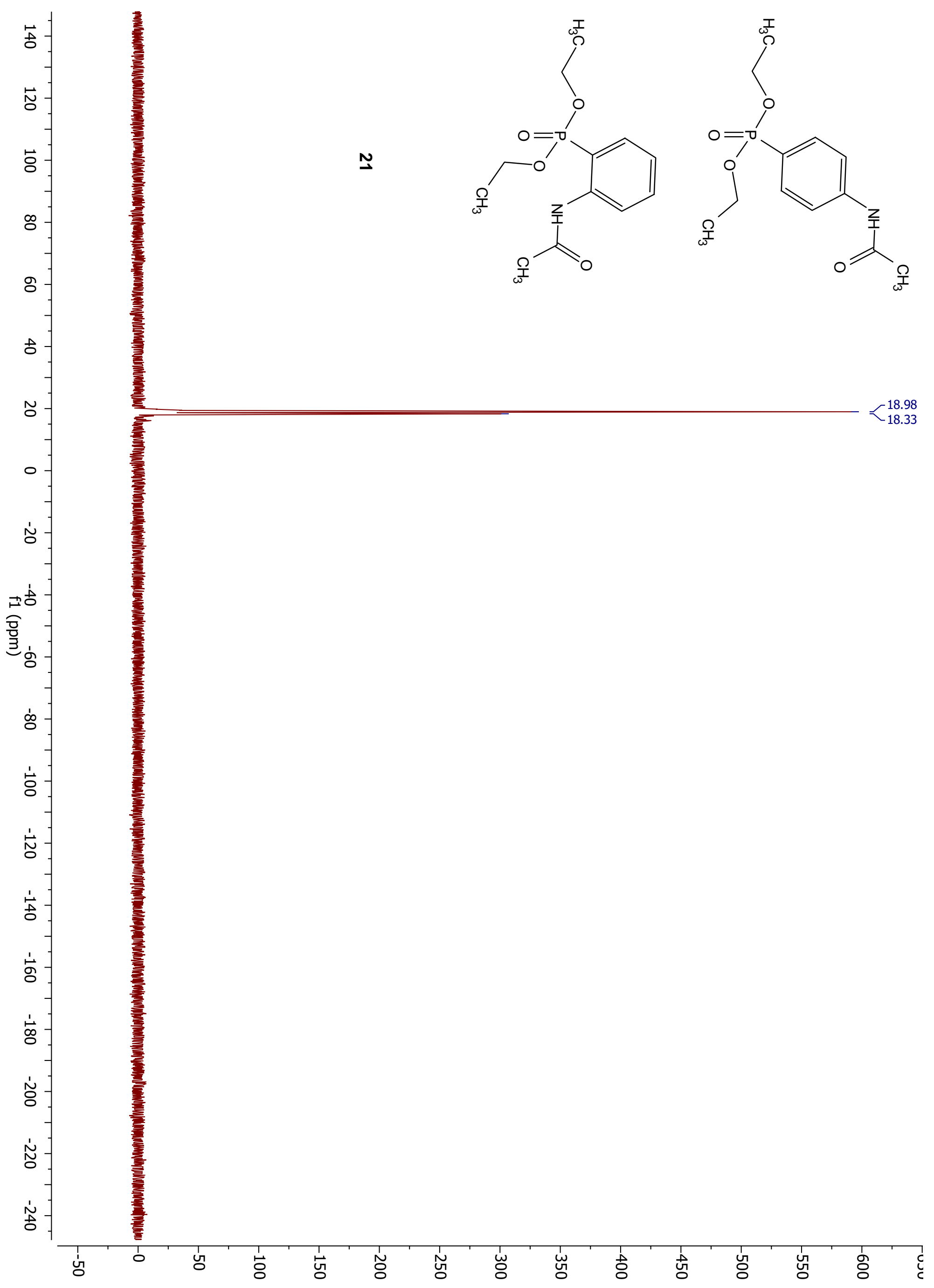




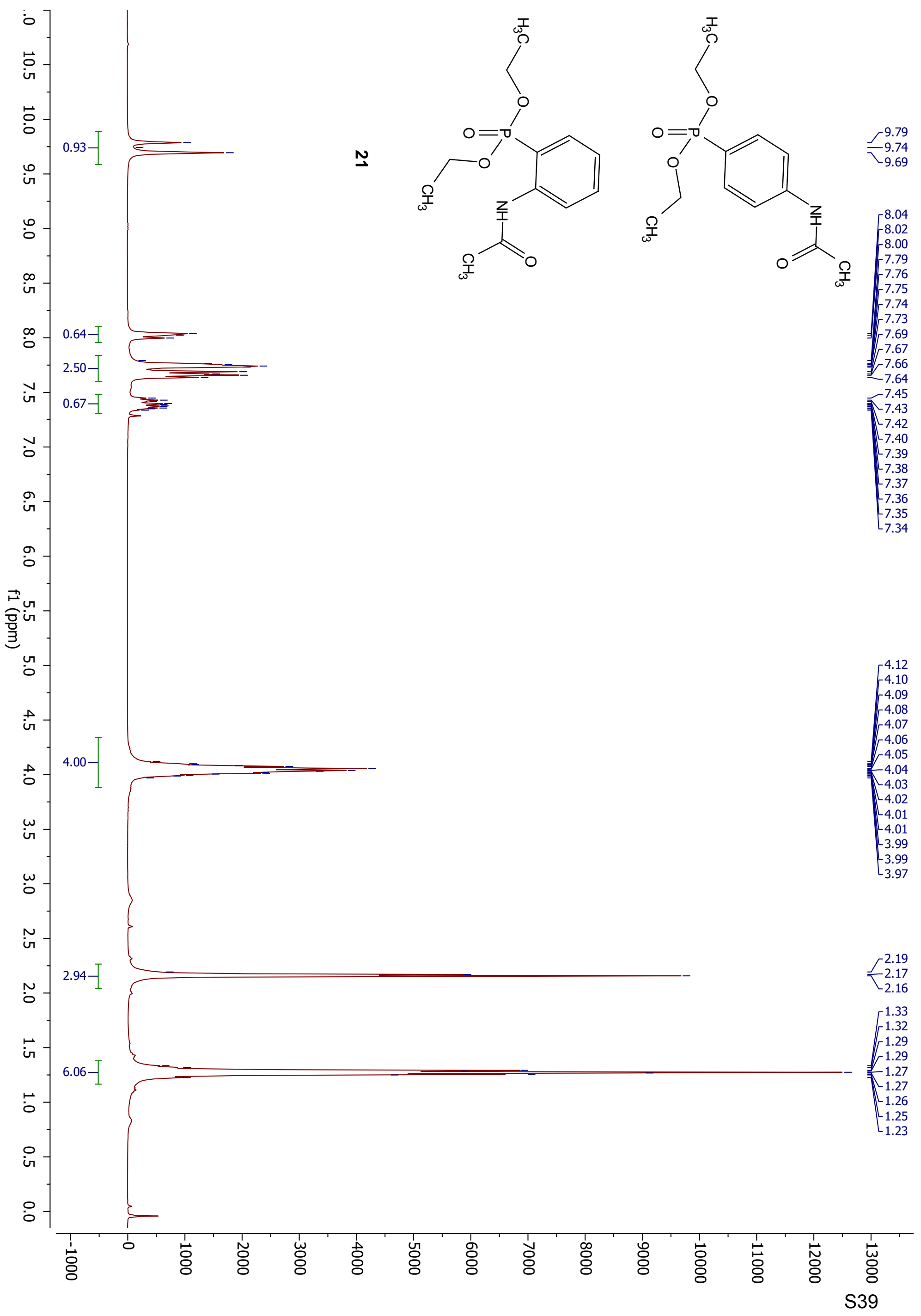




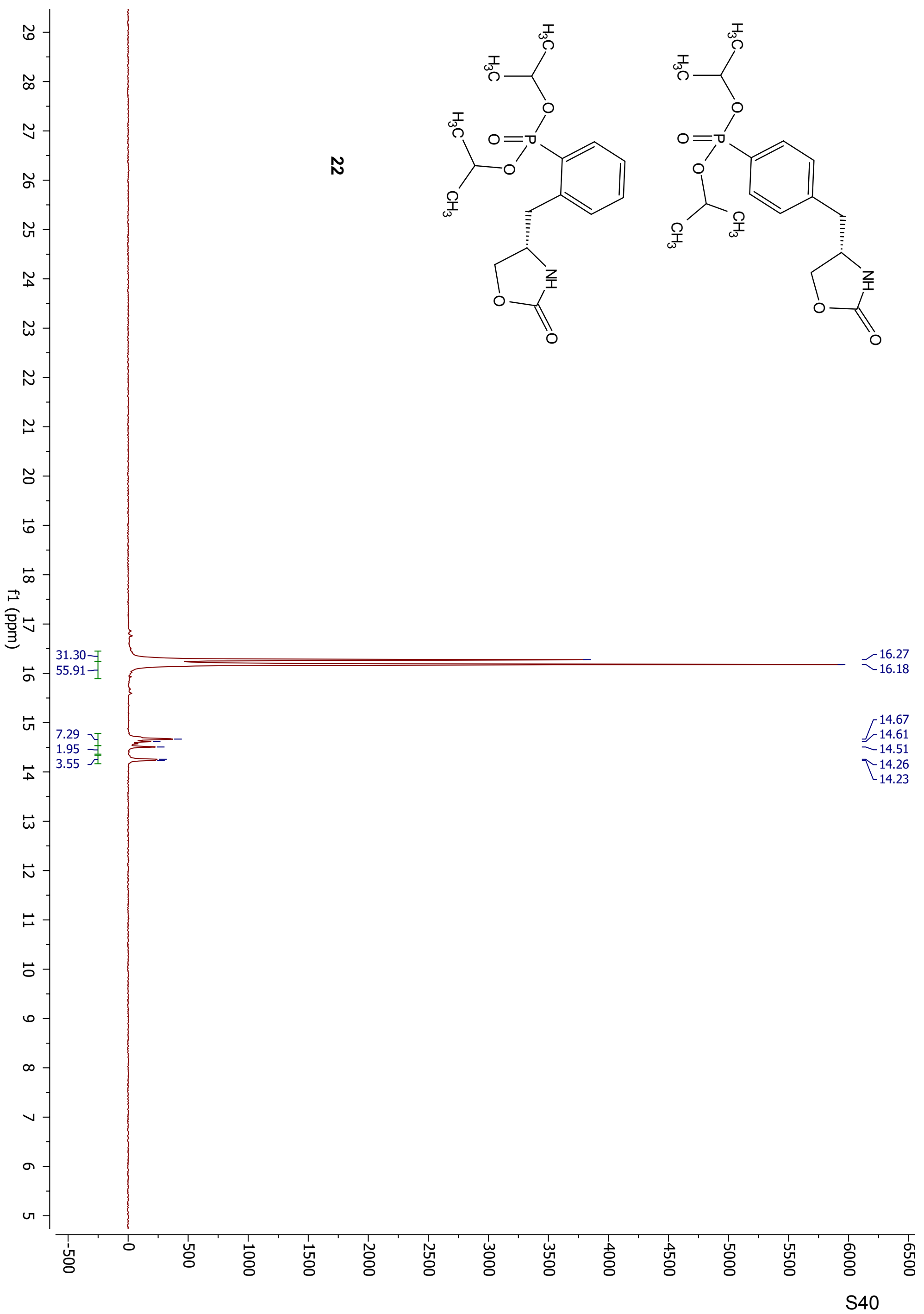




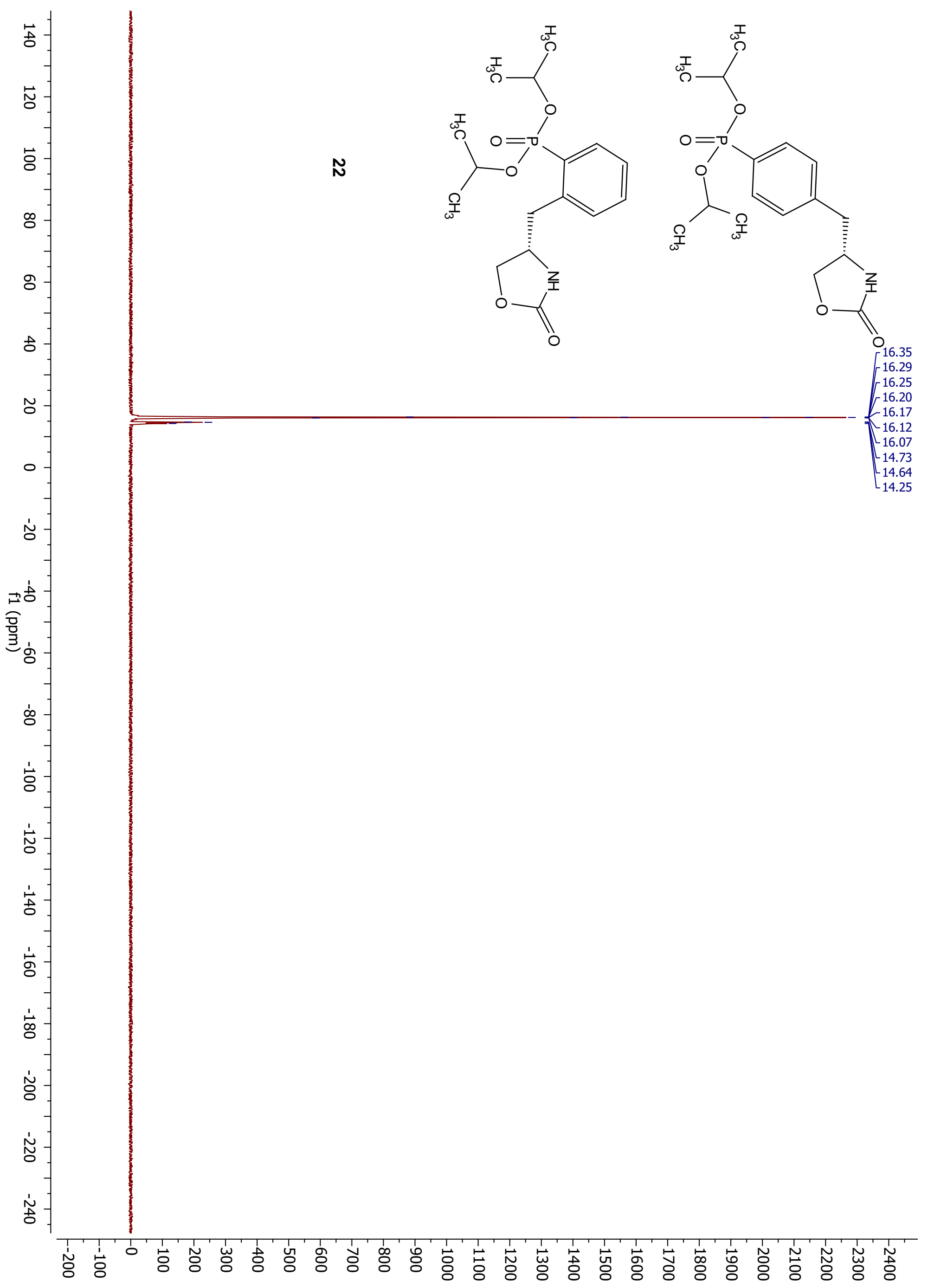




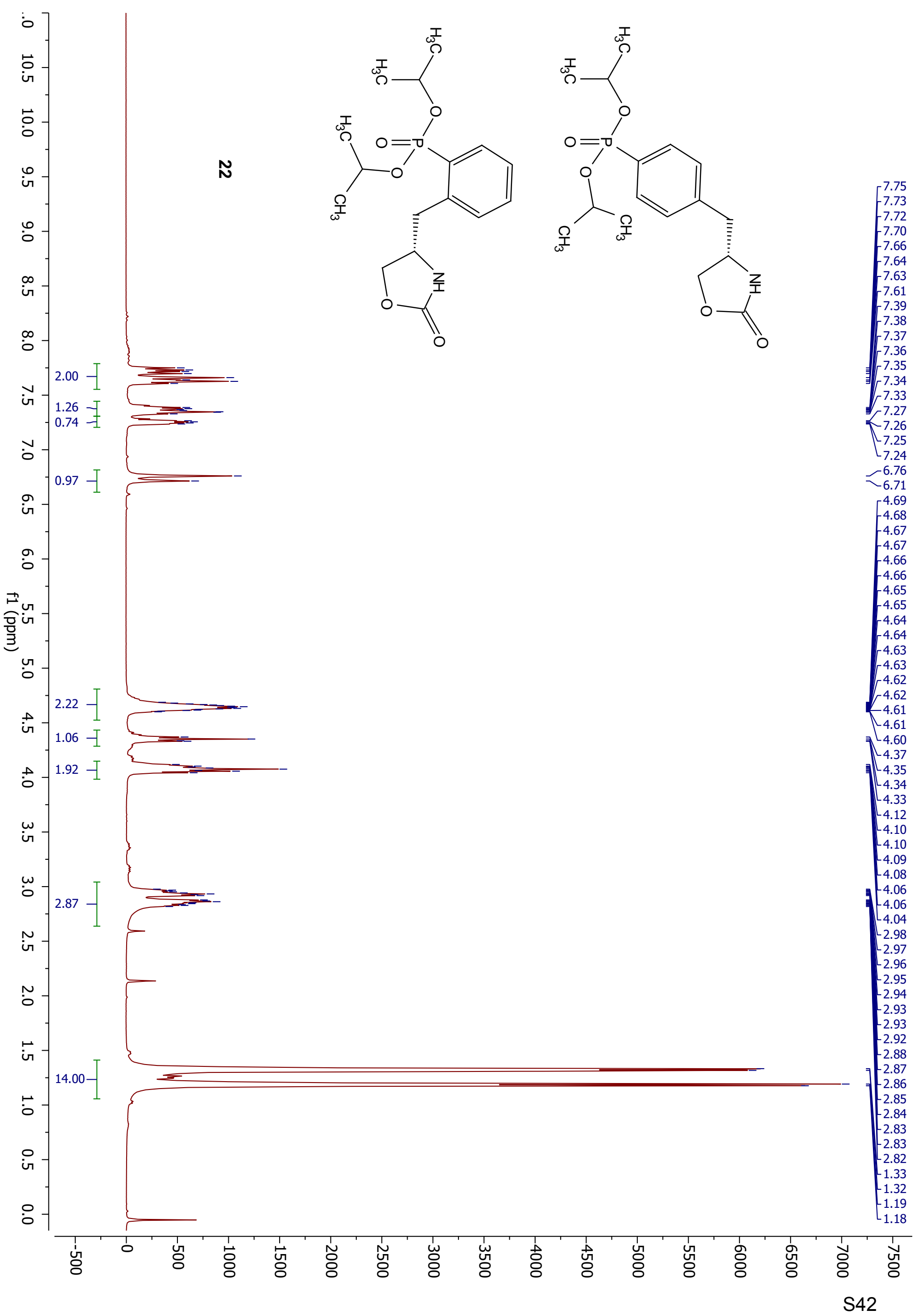




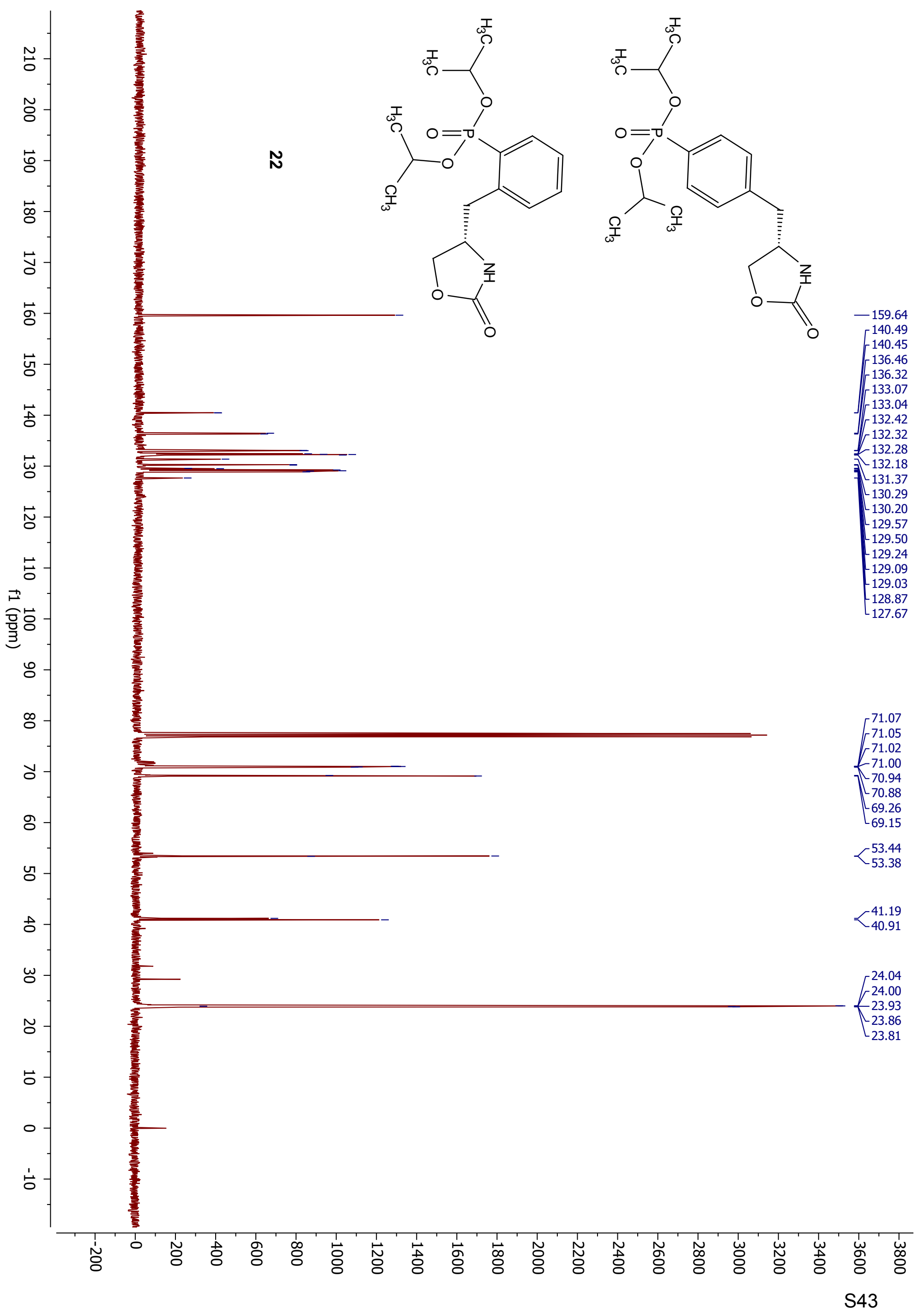




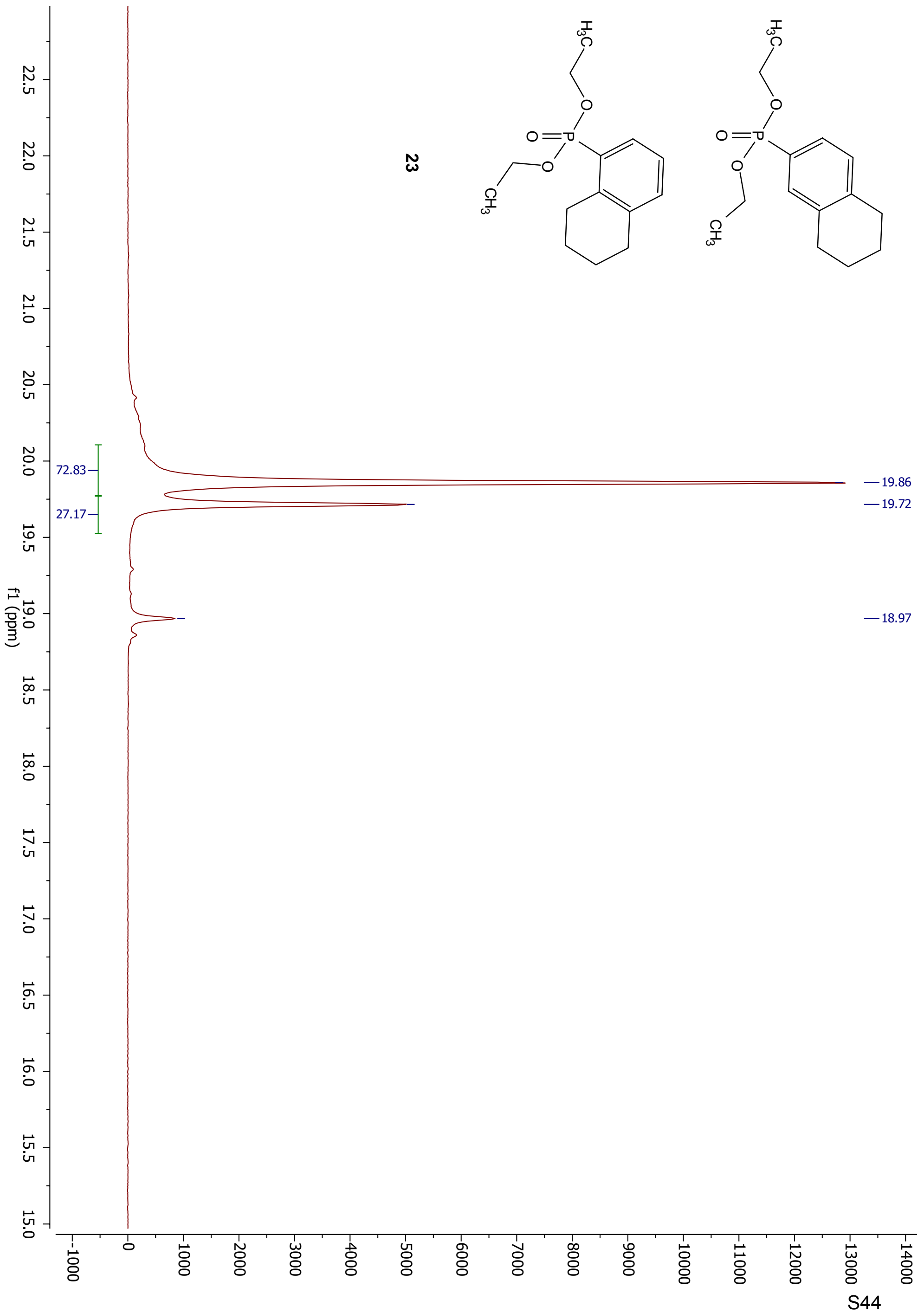




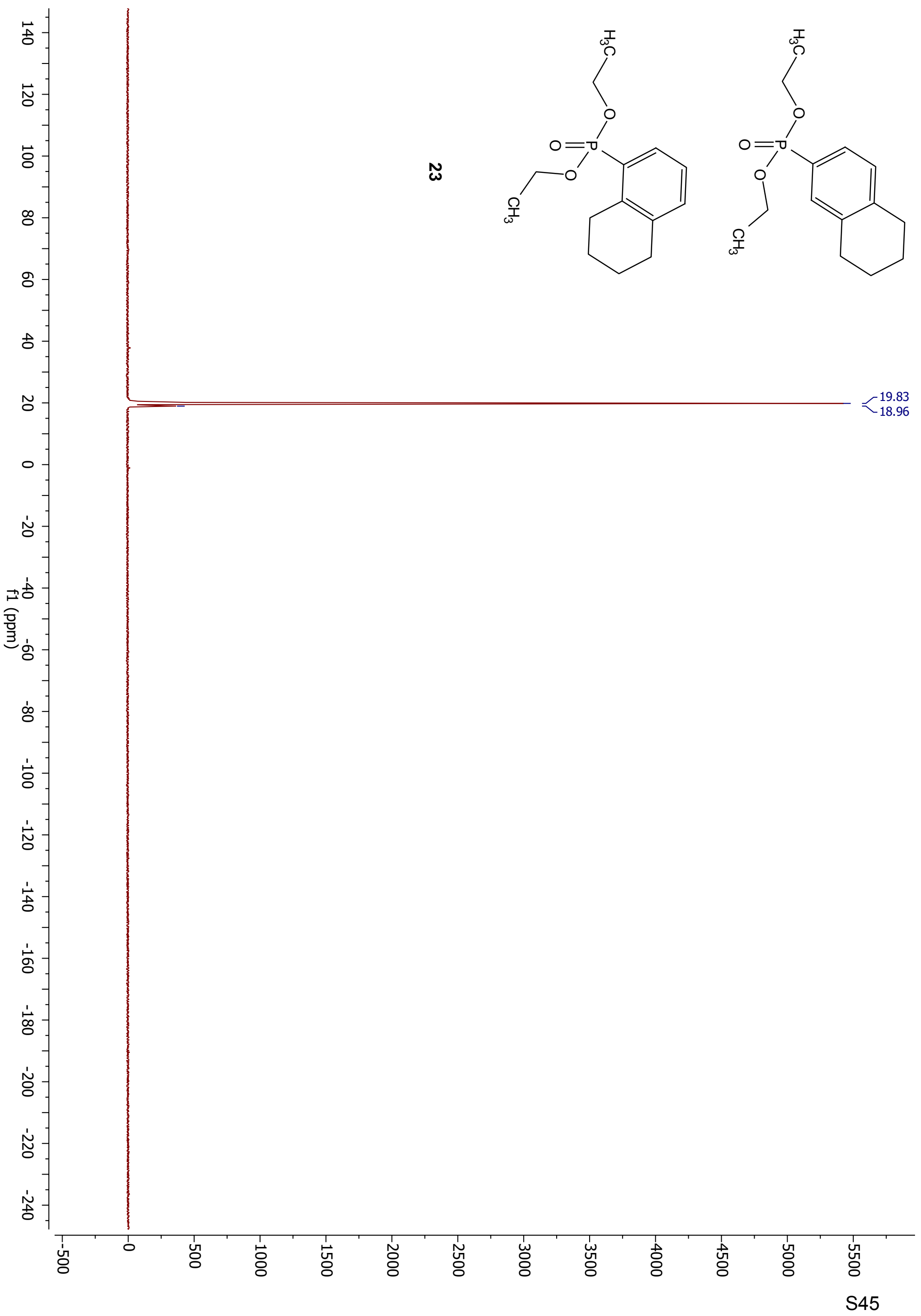




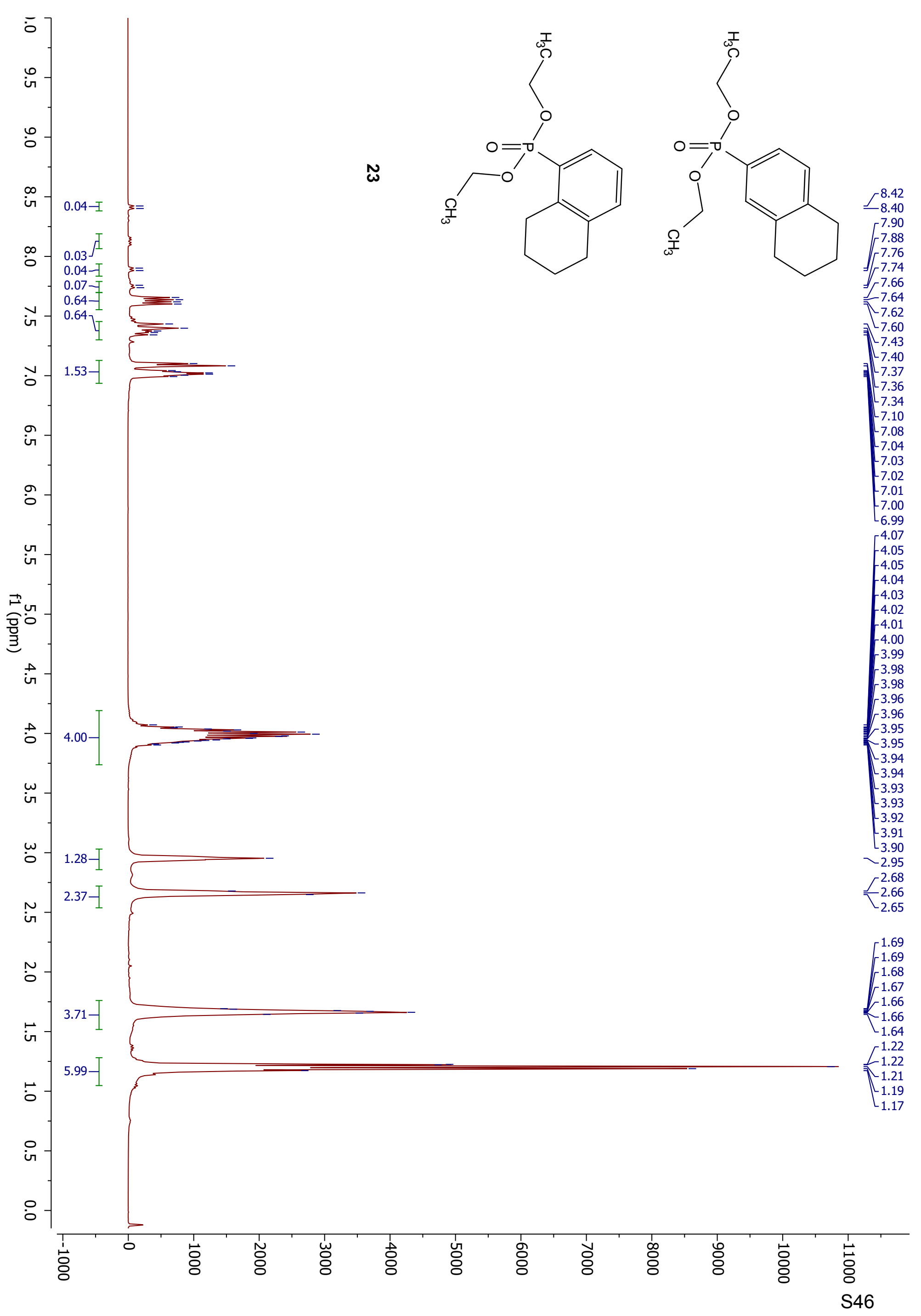




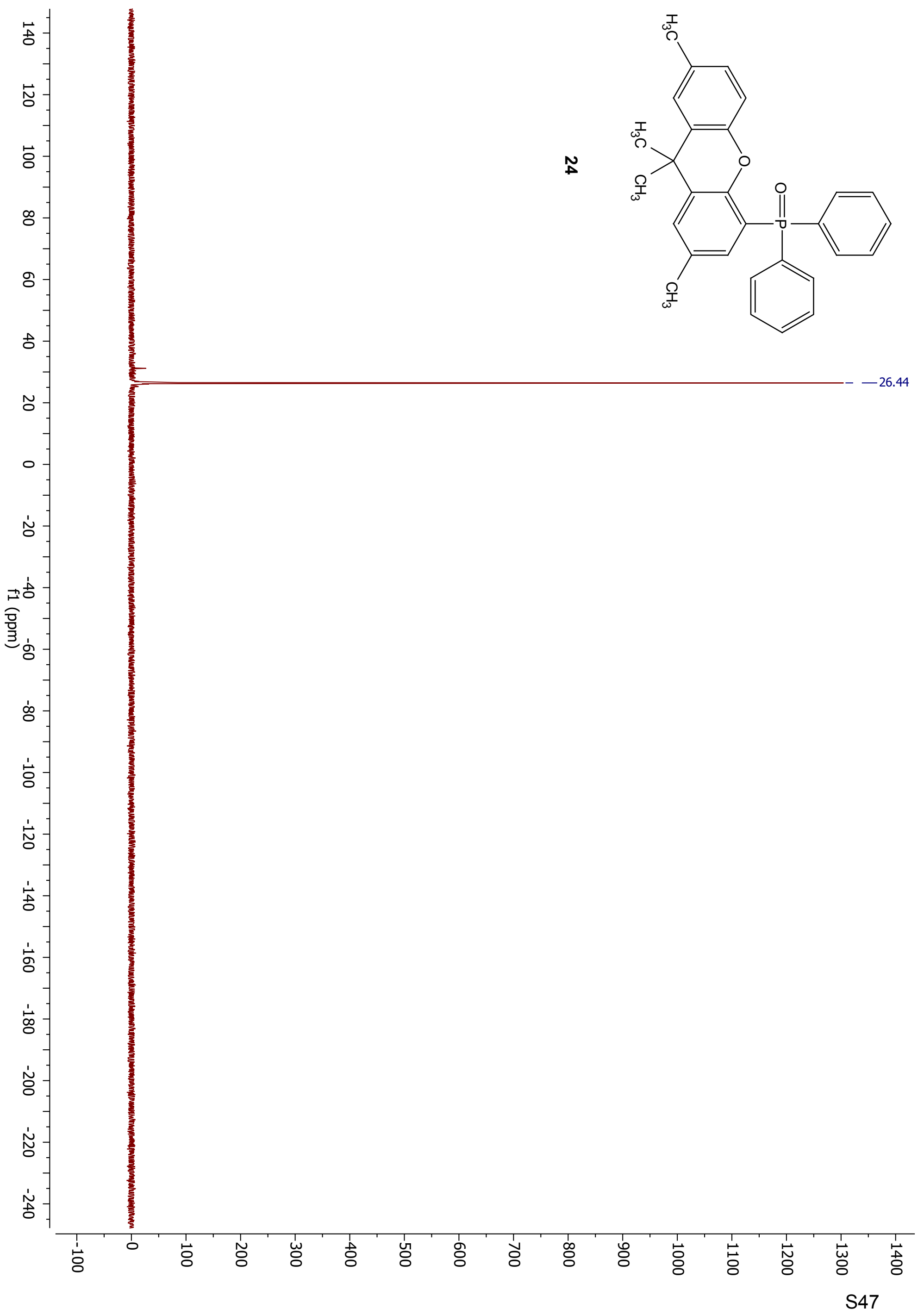




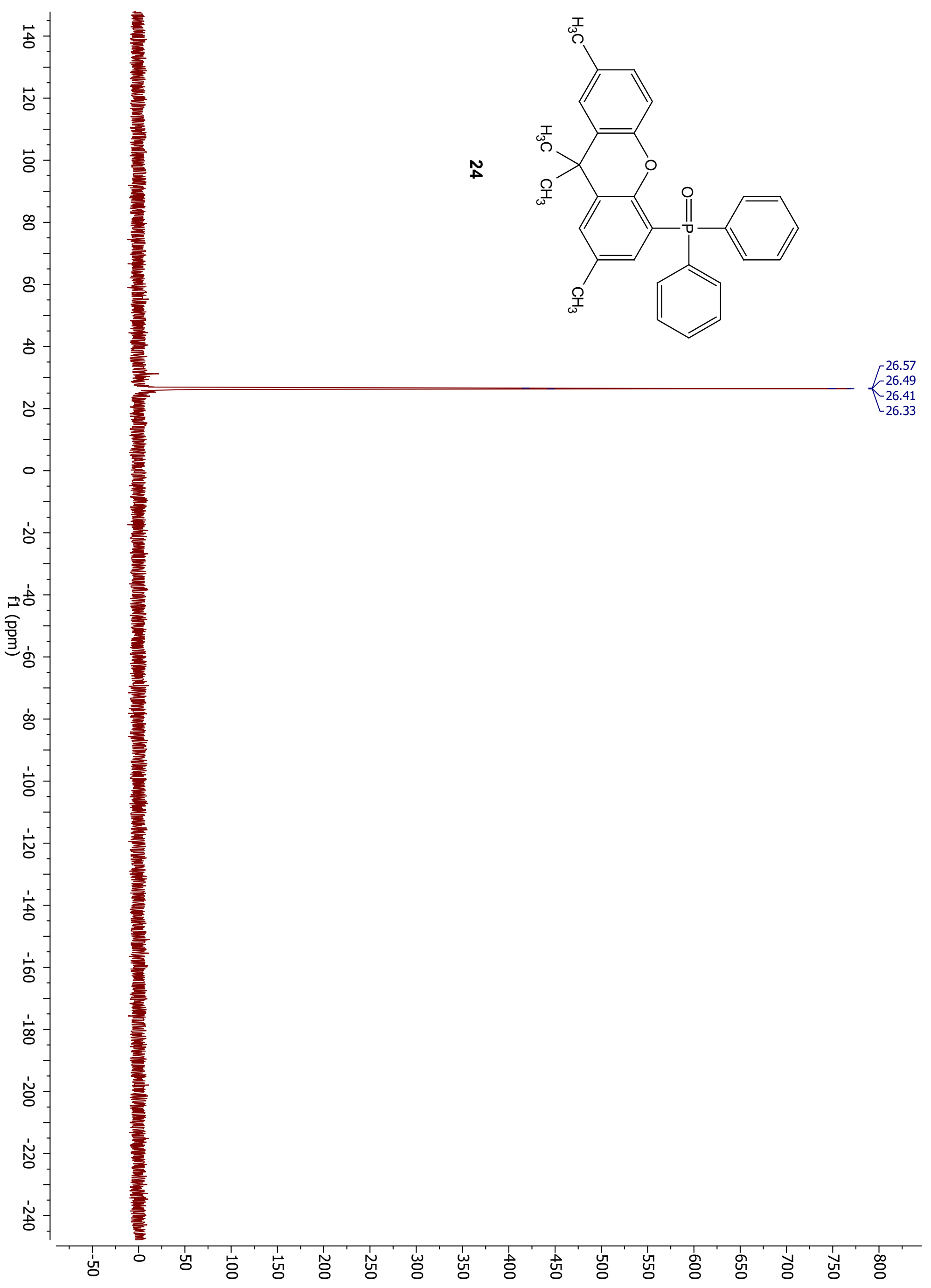




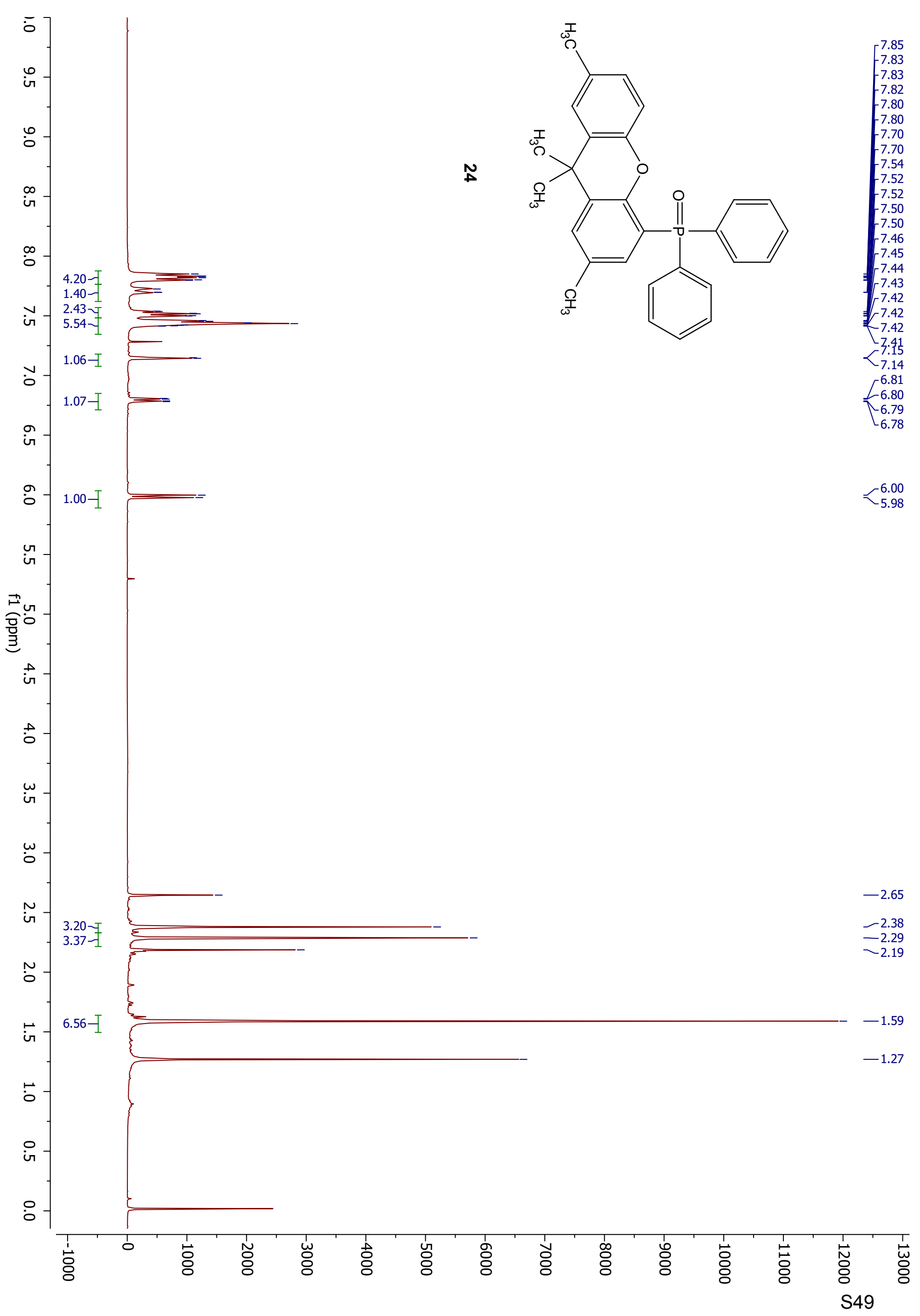




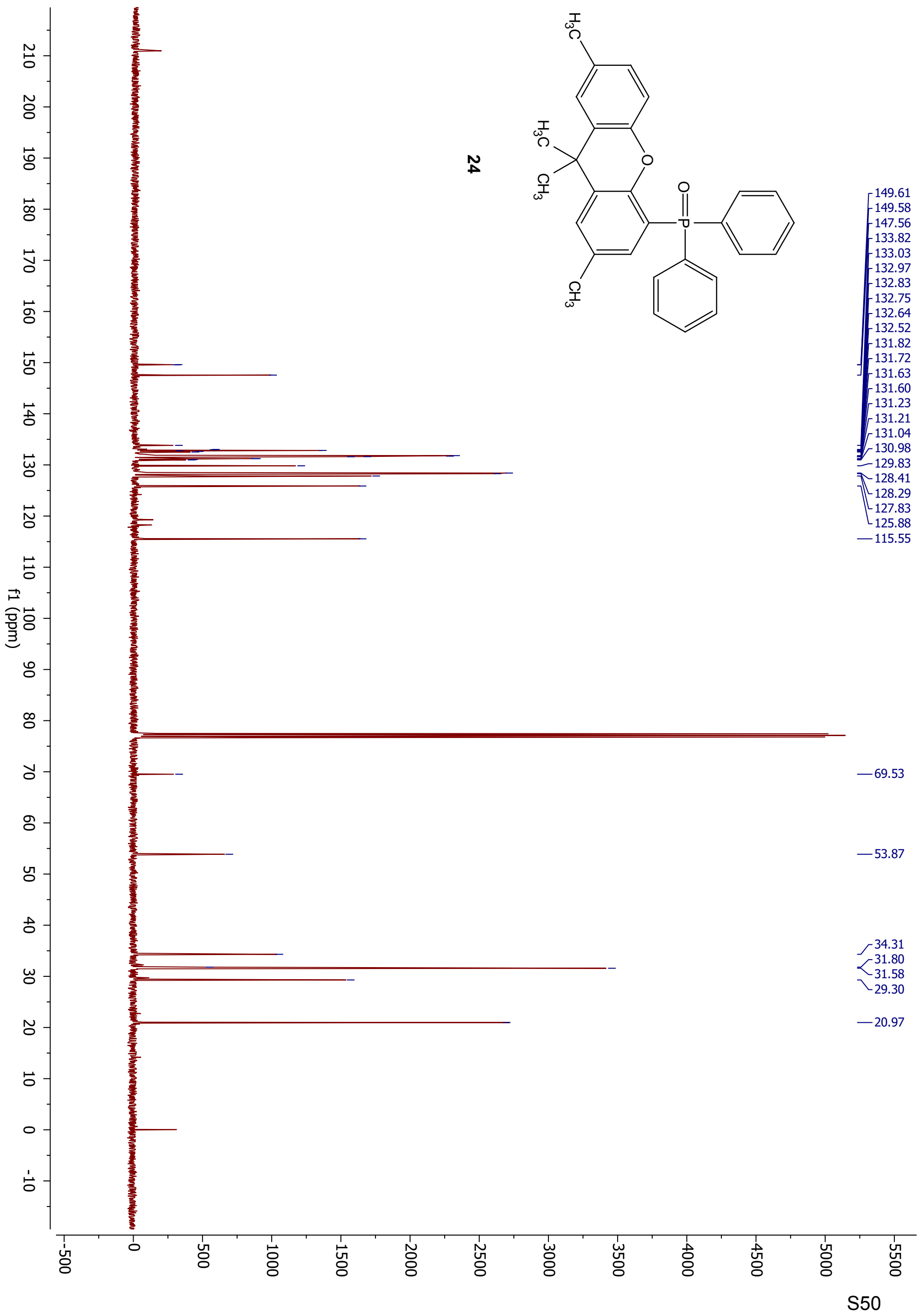




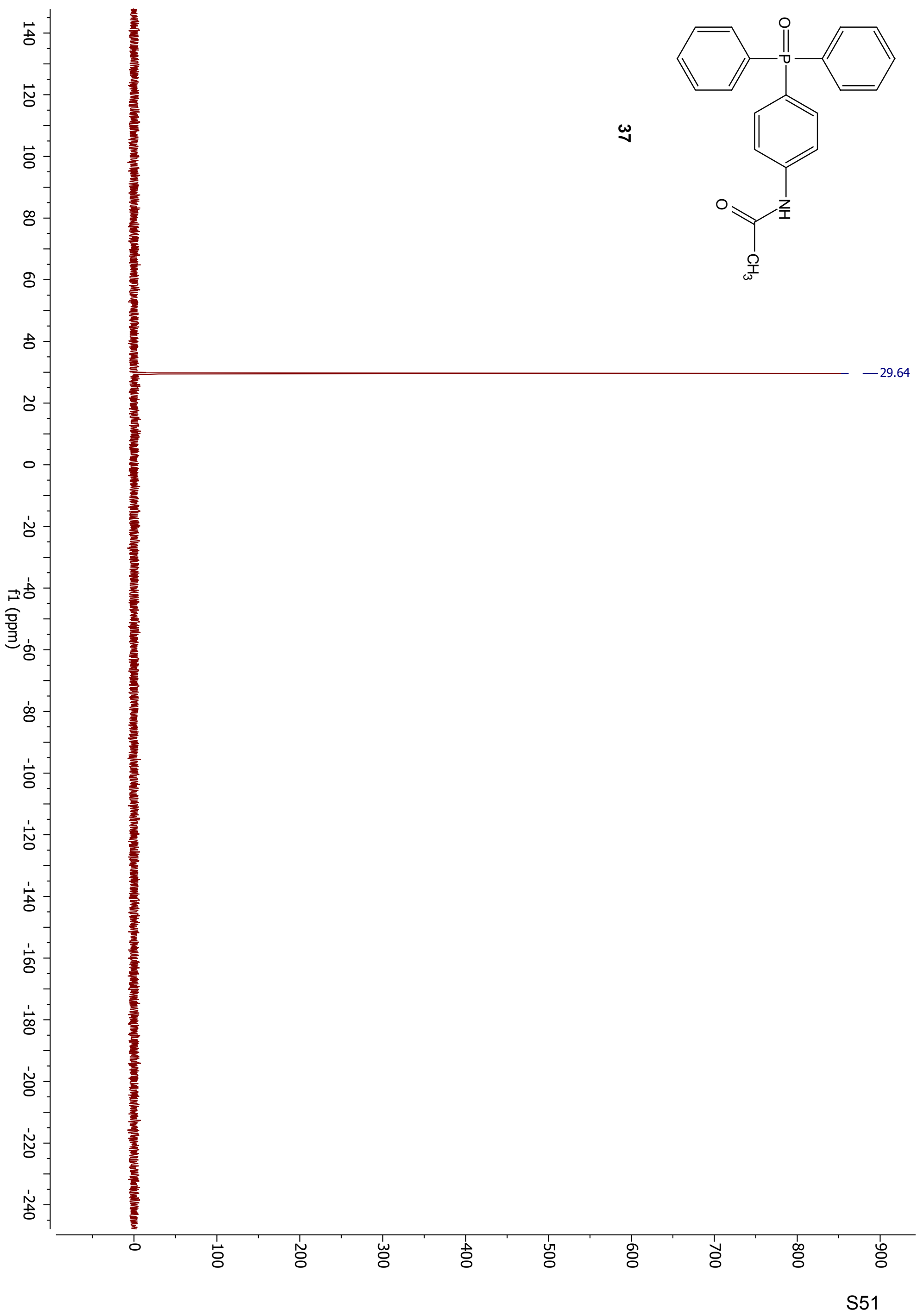




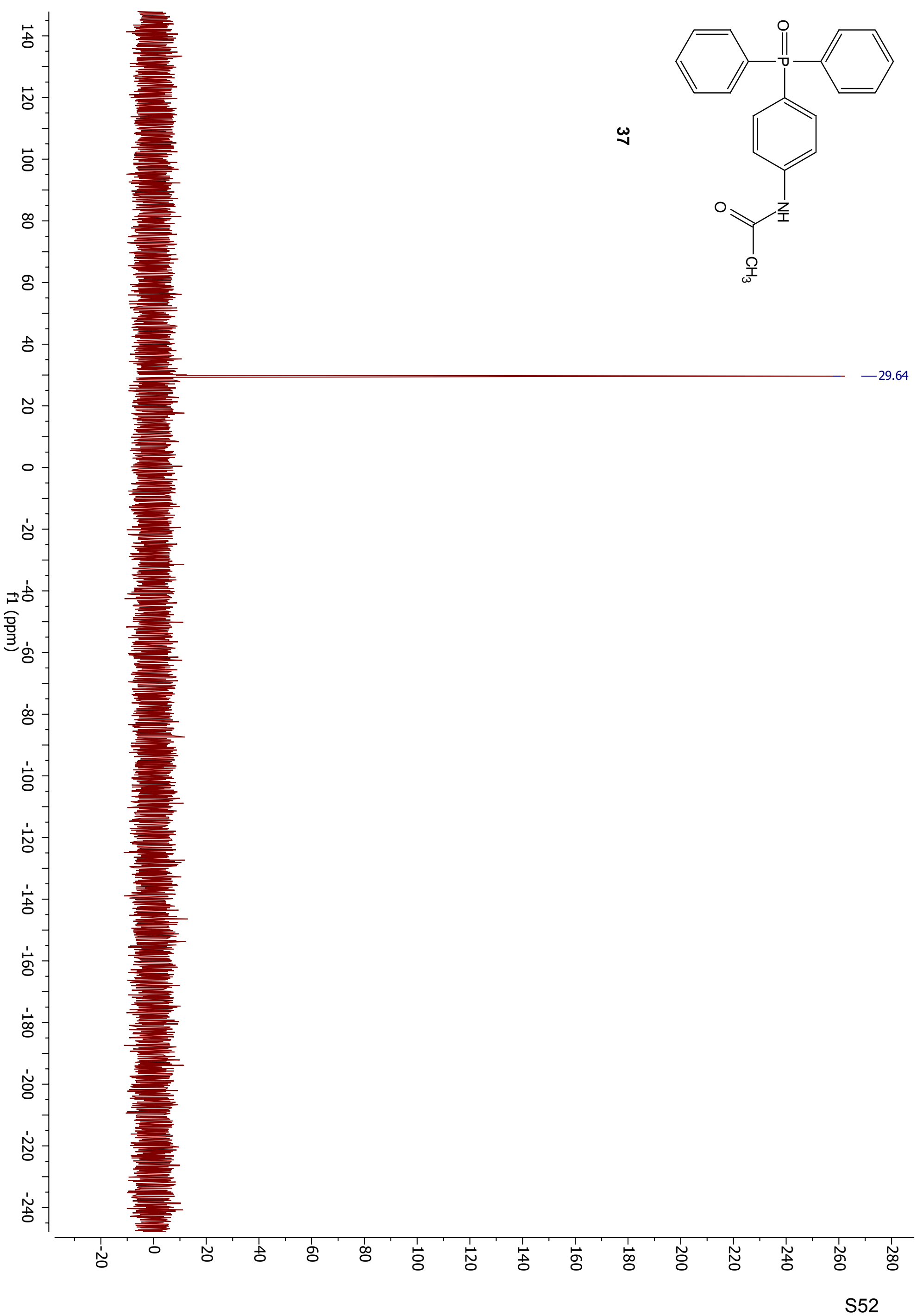




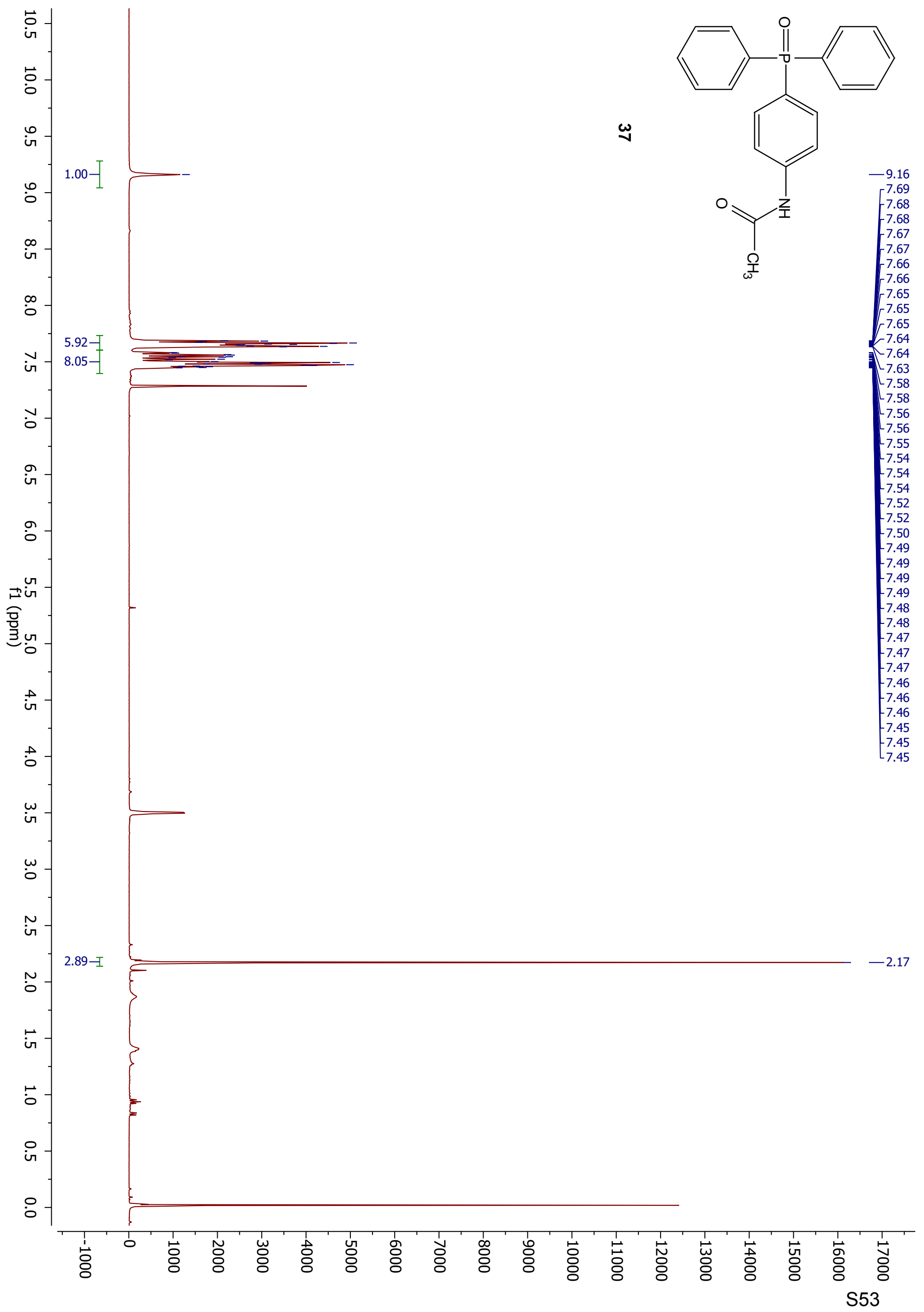



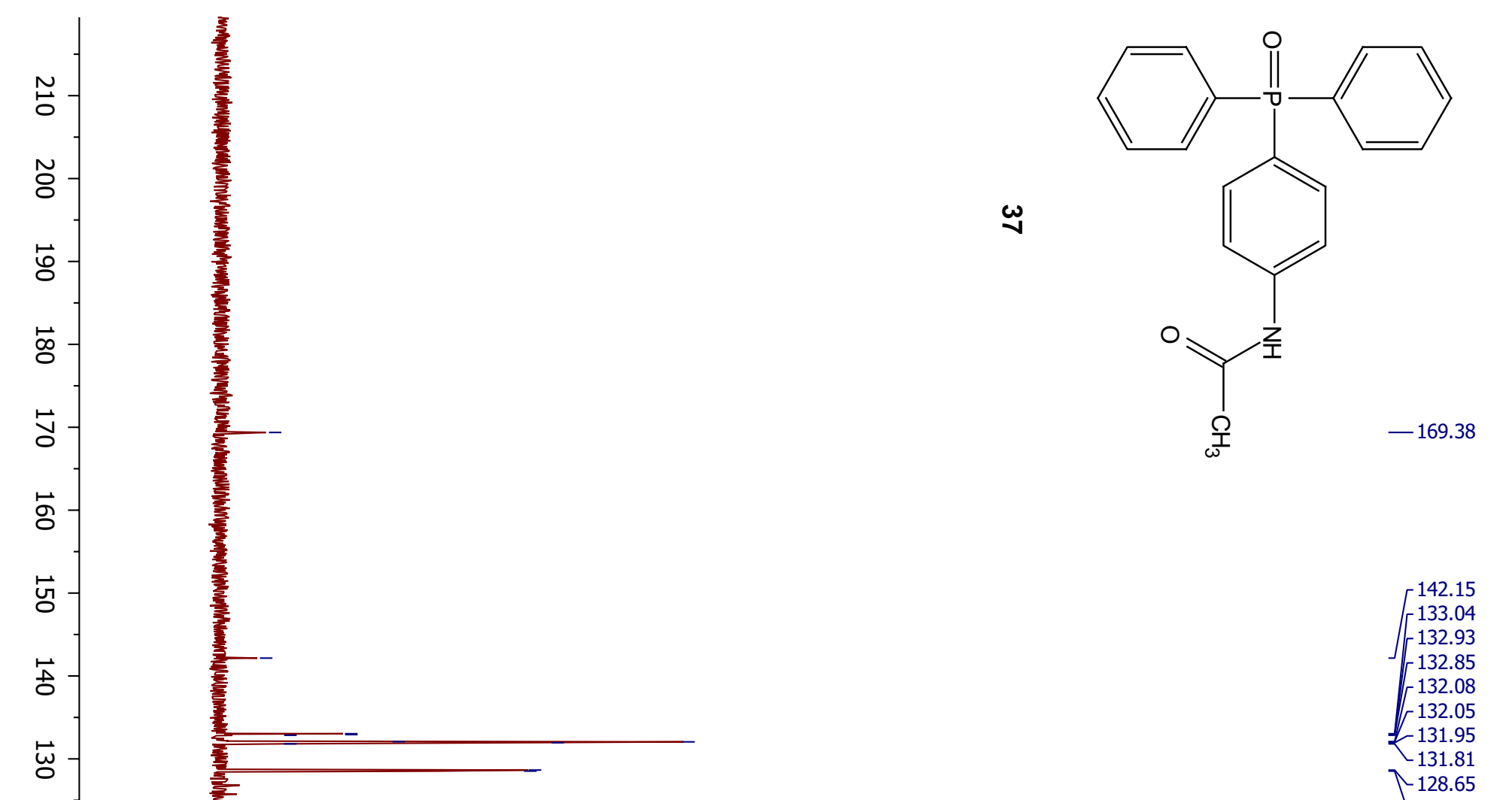

142.15

133.04 132.93

132.85 132.08

132.05

$+131.95$

131.81

$-128.65$

128.53

$<\begin{array}{r}119.62 \\ 119.49\end{array}$

్ㅡㅁ

官

额

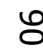

$\infty$

๖ั

용

v

o

$\omega$

ธ

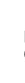

s

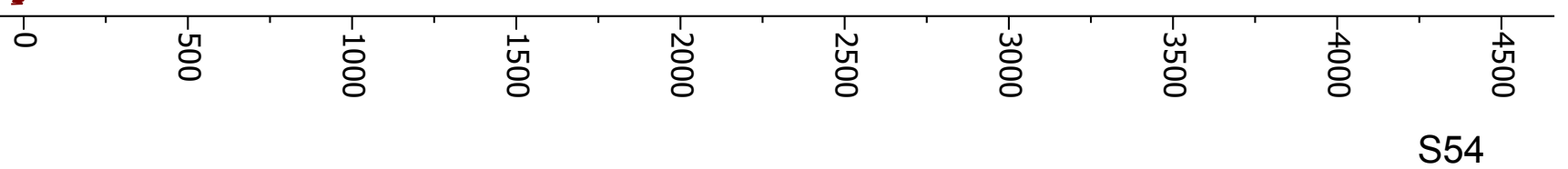




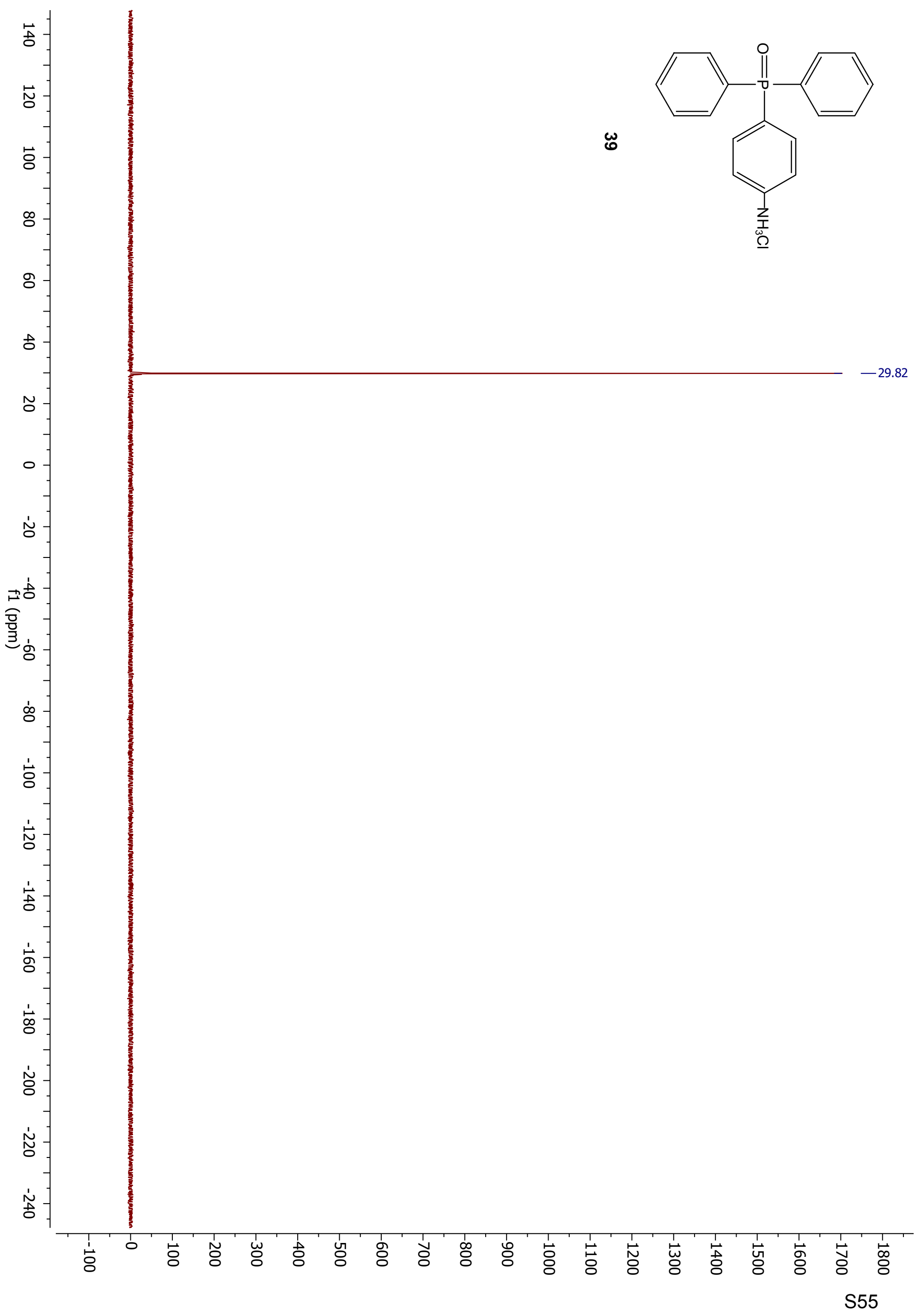




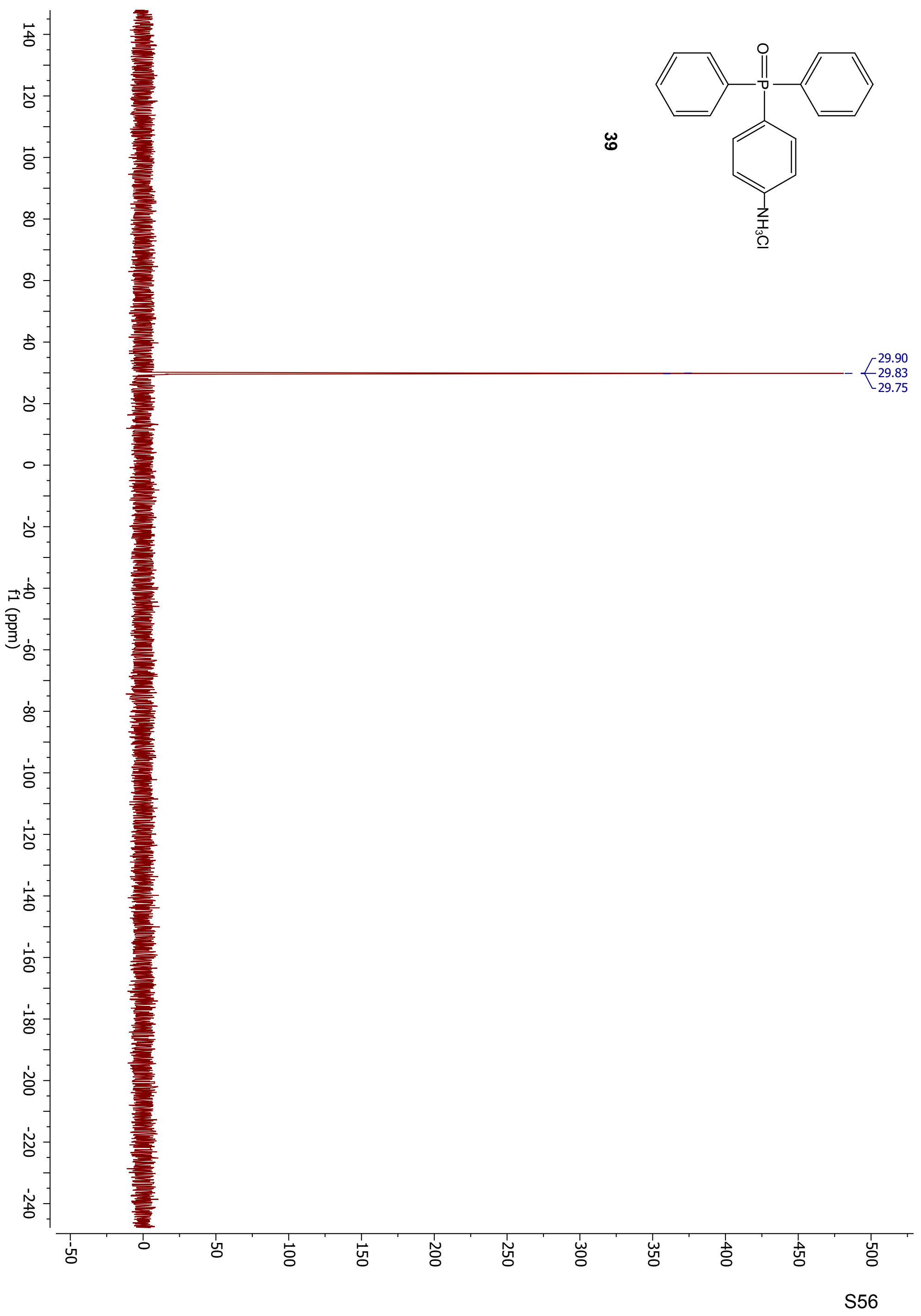




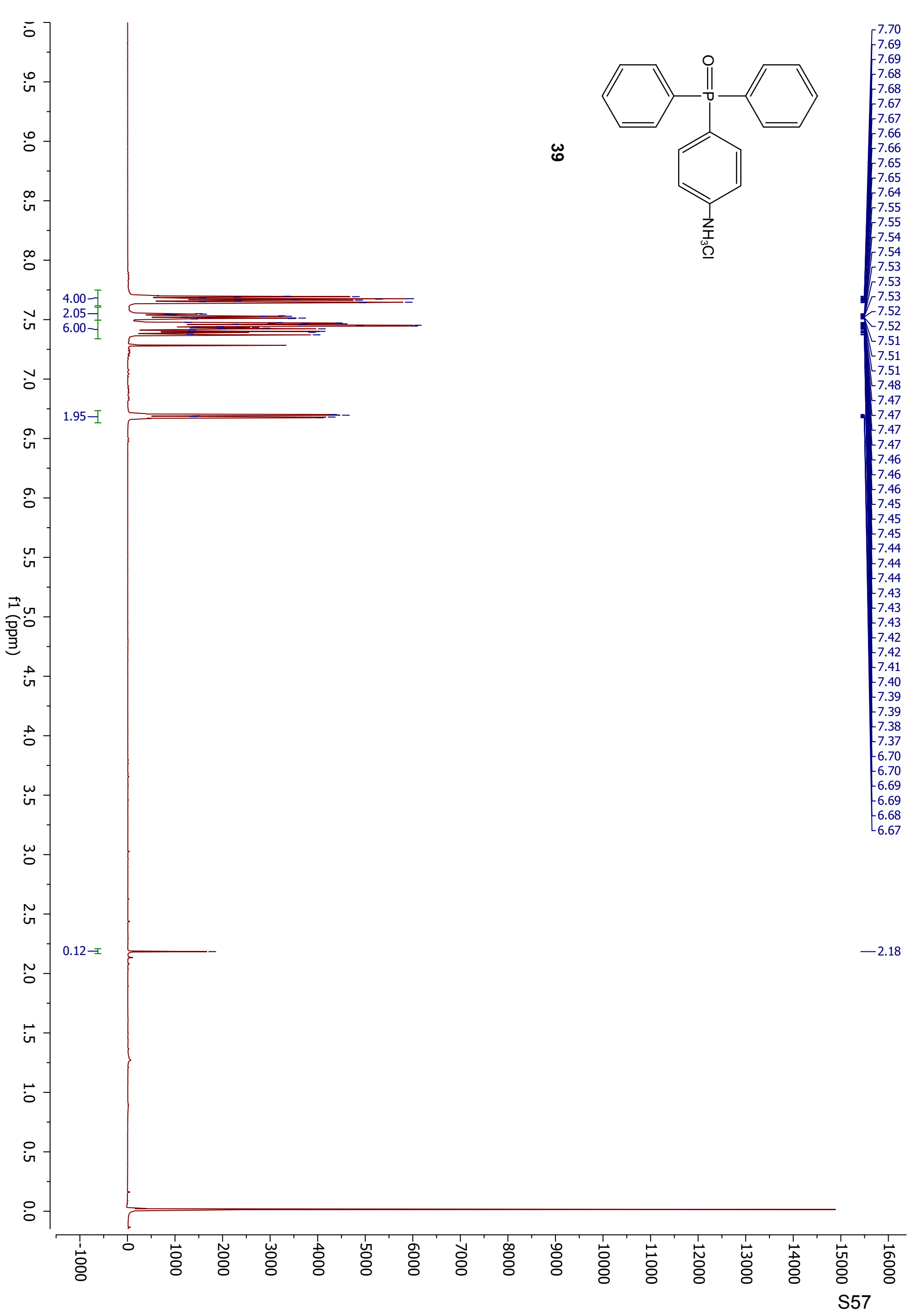




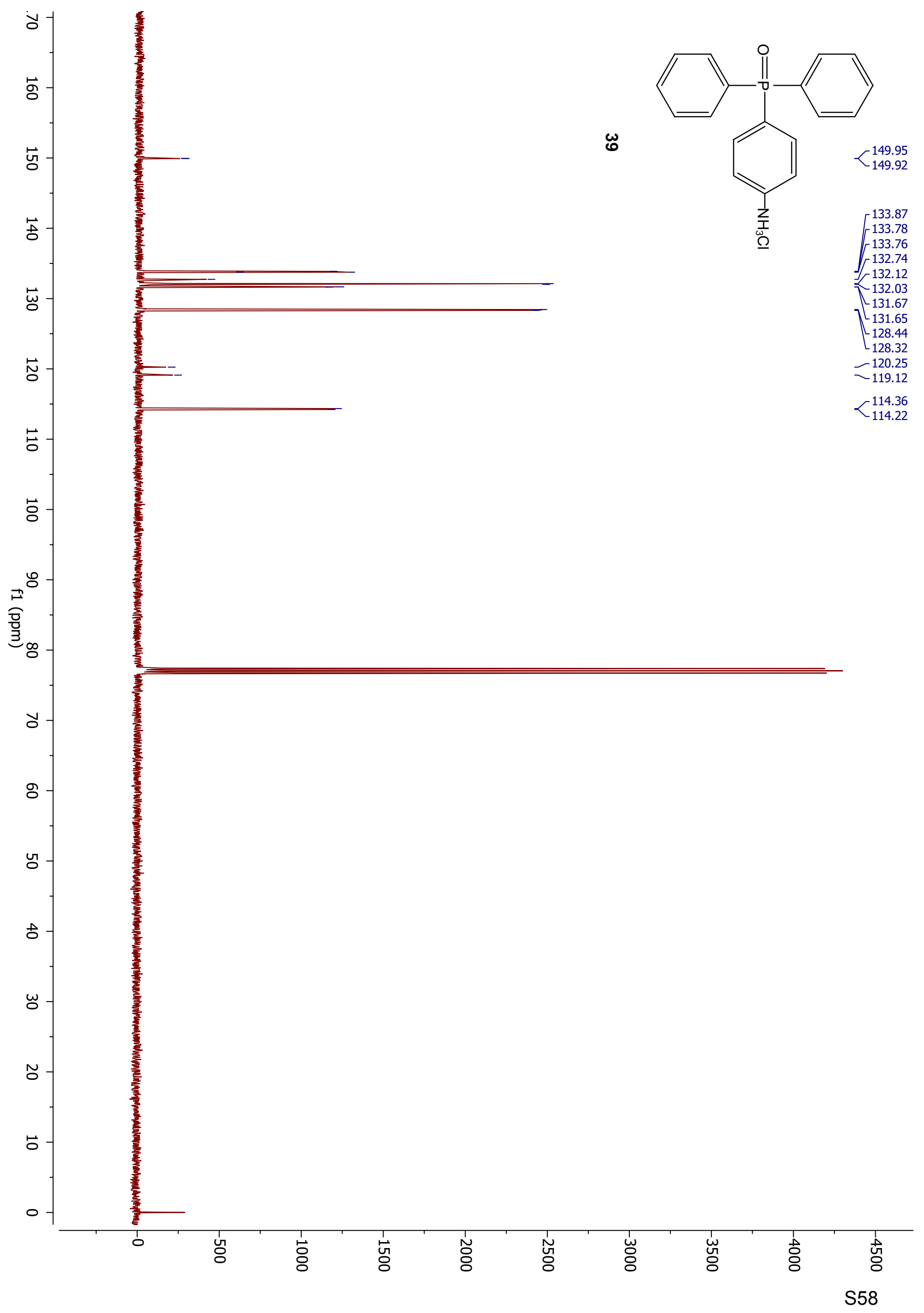




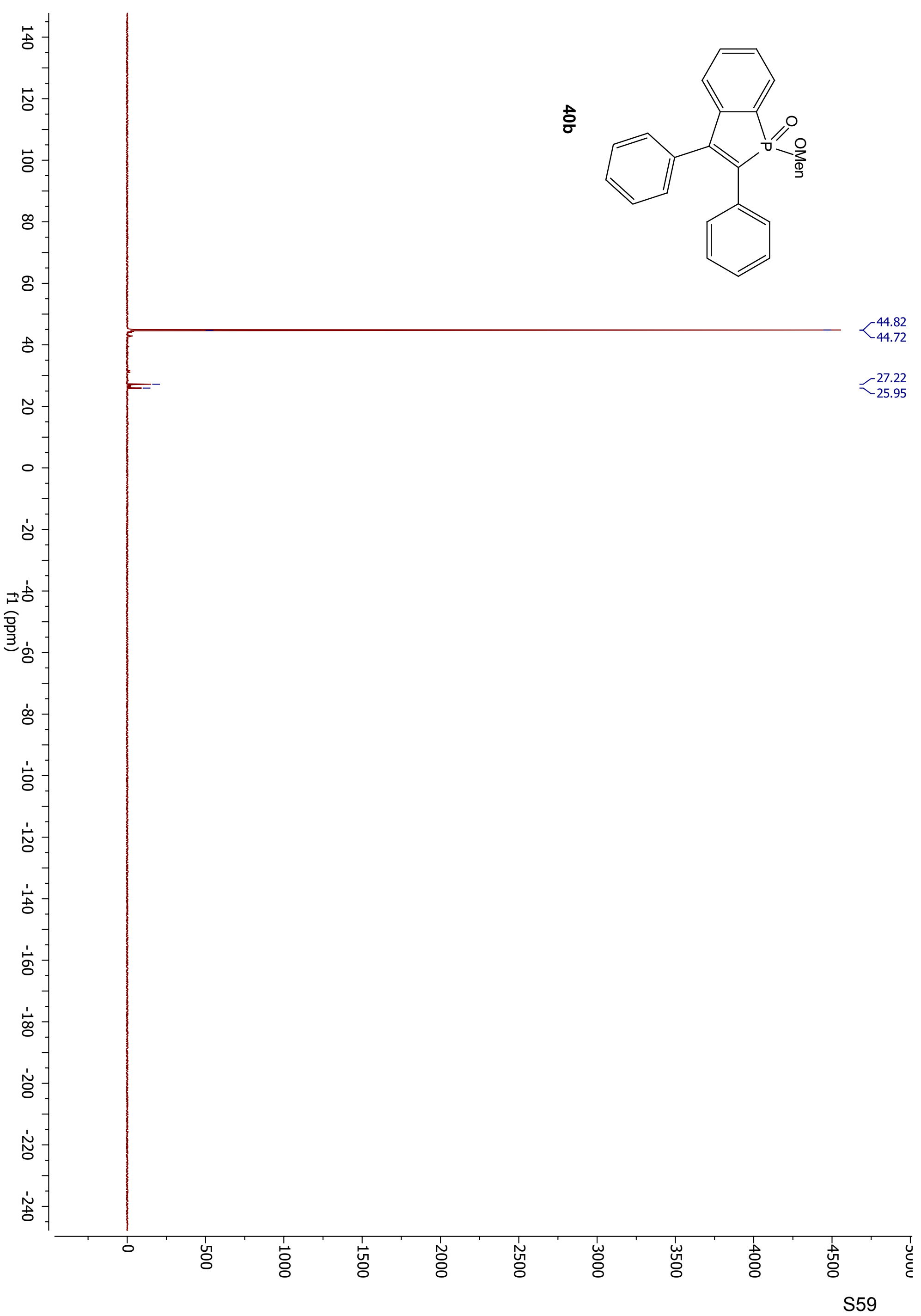




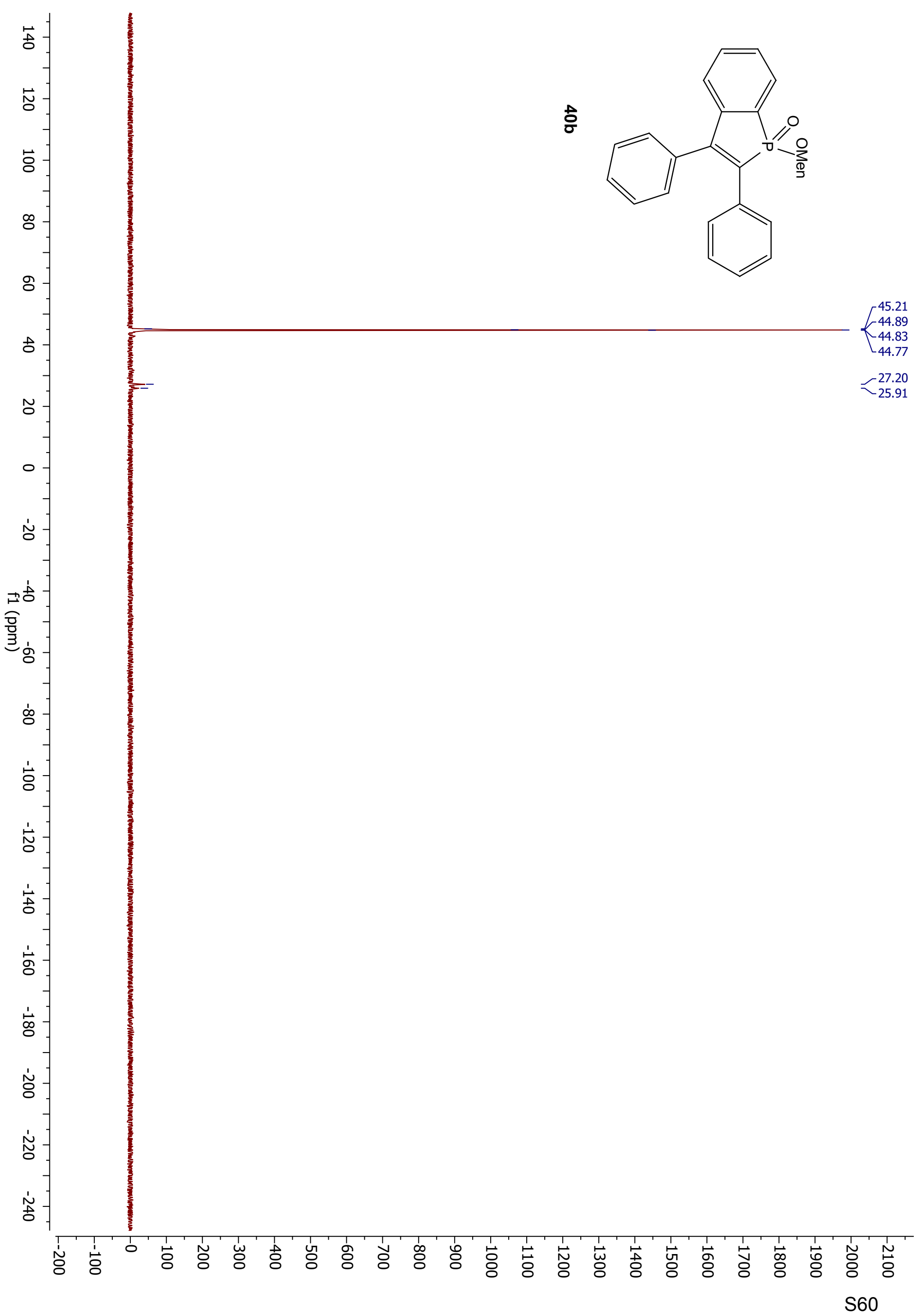



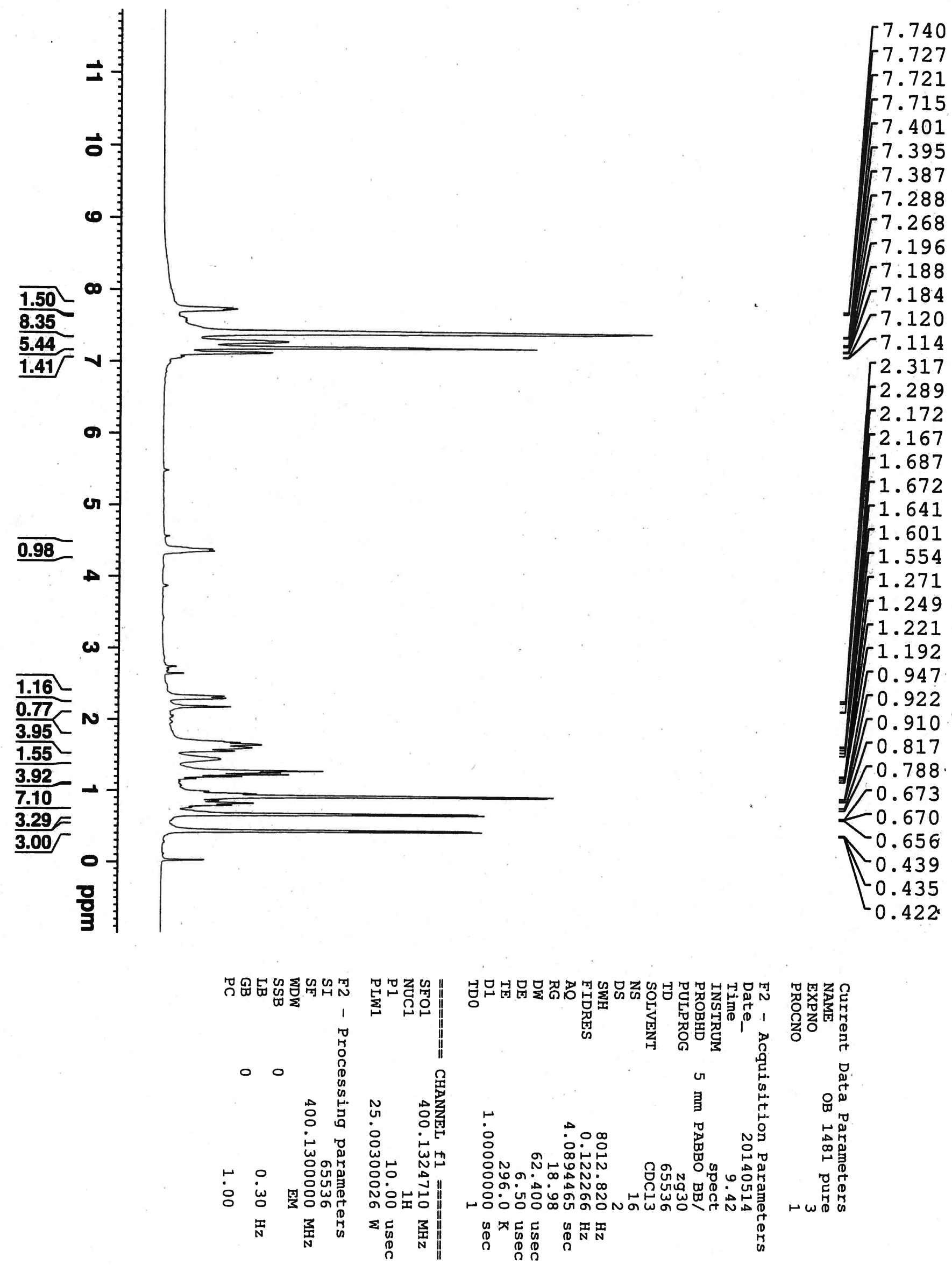


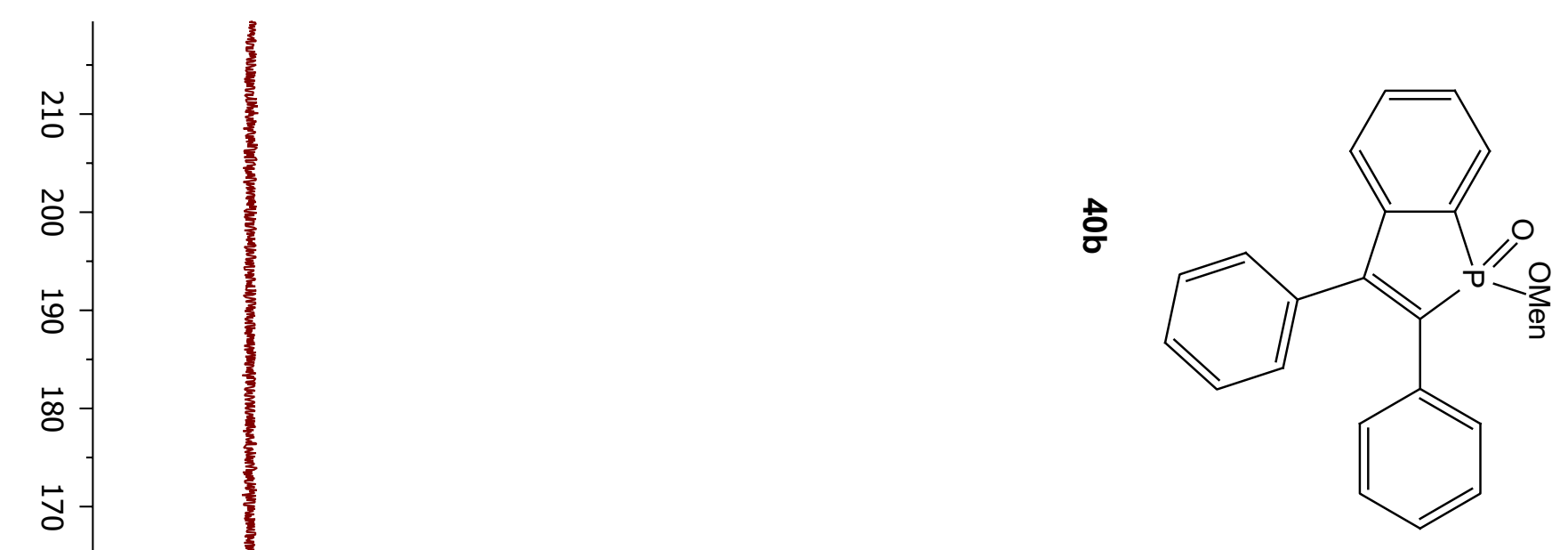

횽

뱅

悎

๖్

N

물

을

8

$\infty$

১

8

.

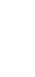

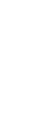

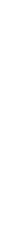

(1)

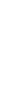

. 


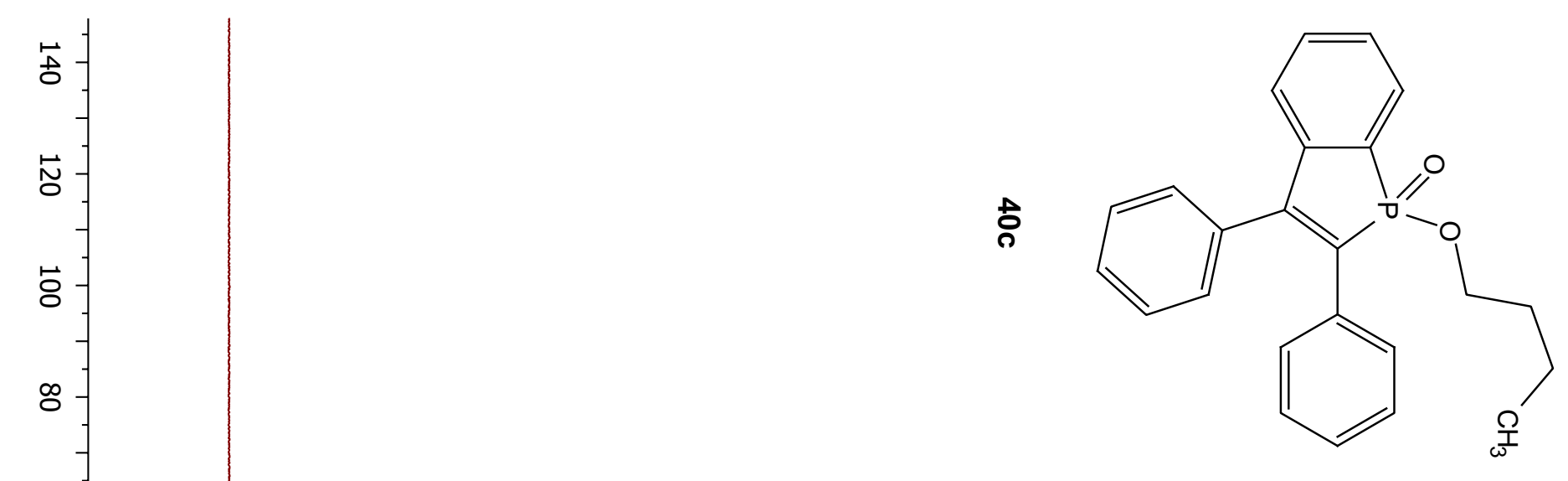




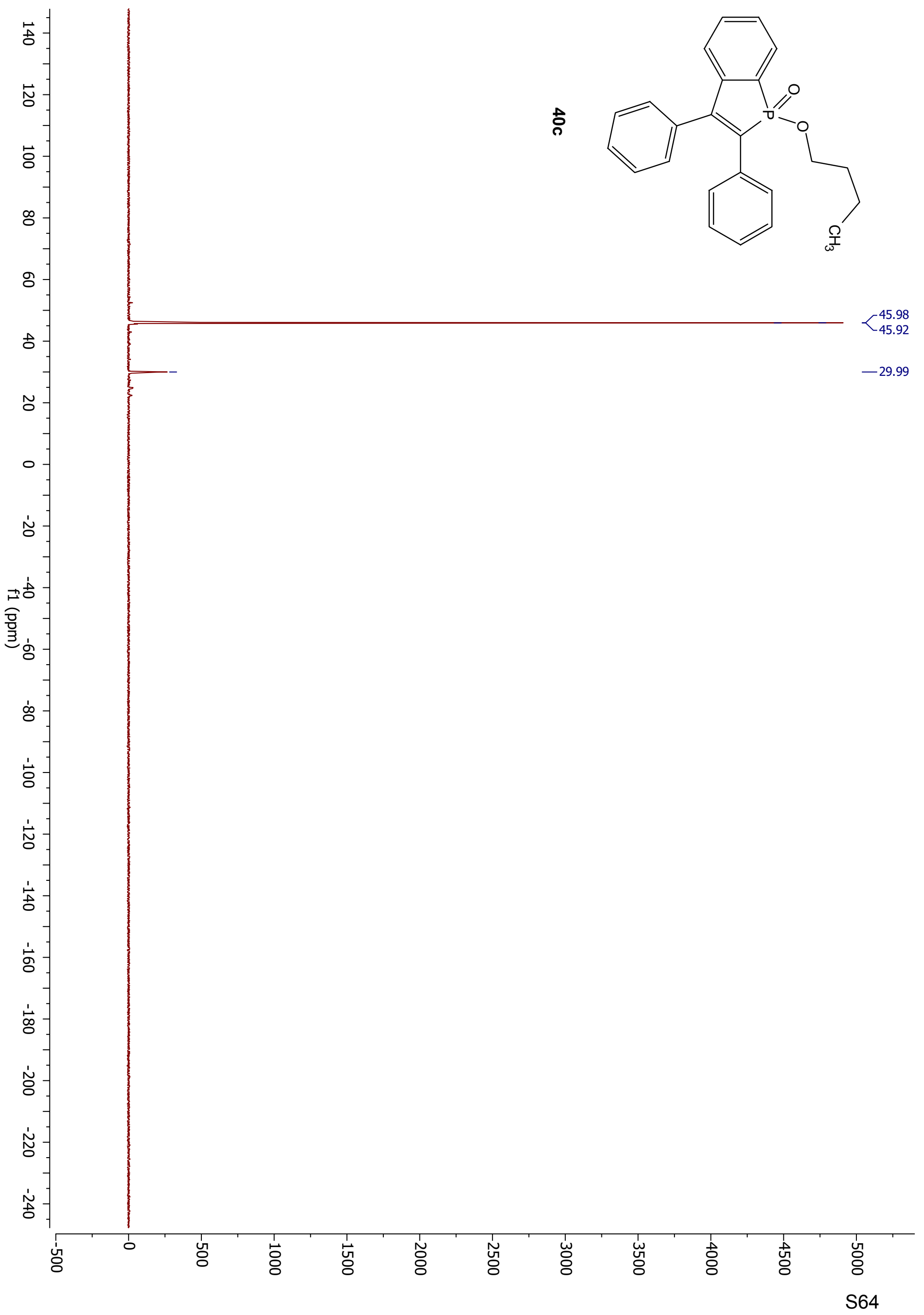




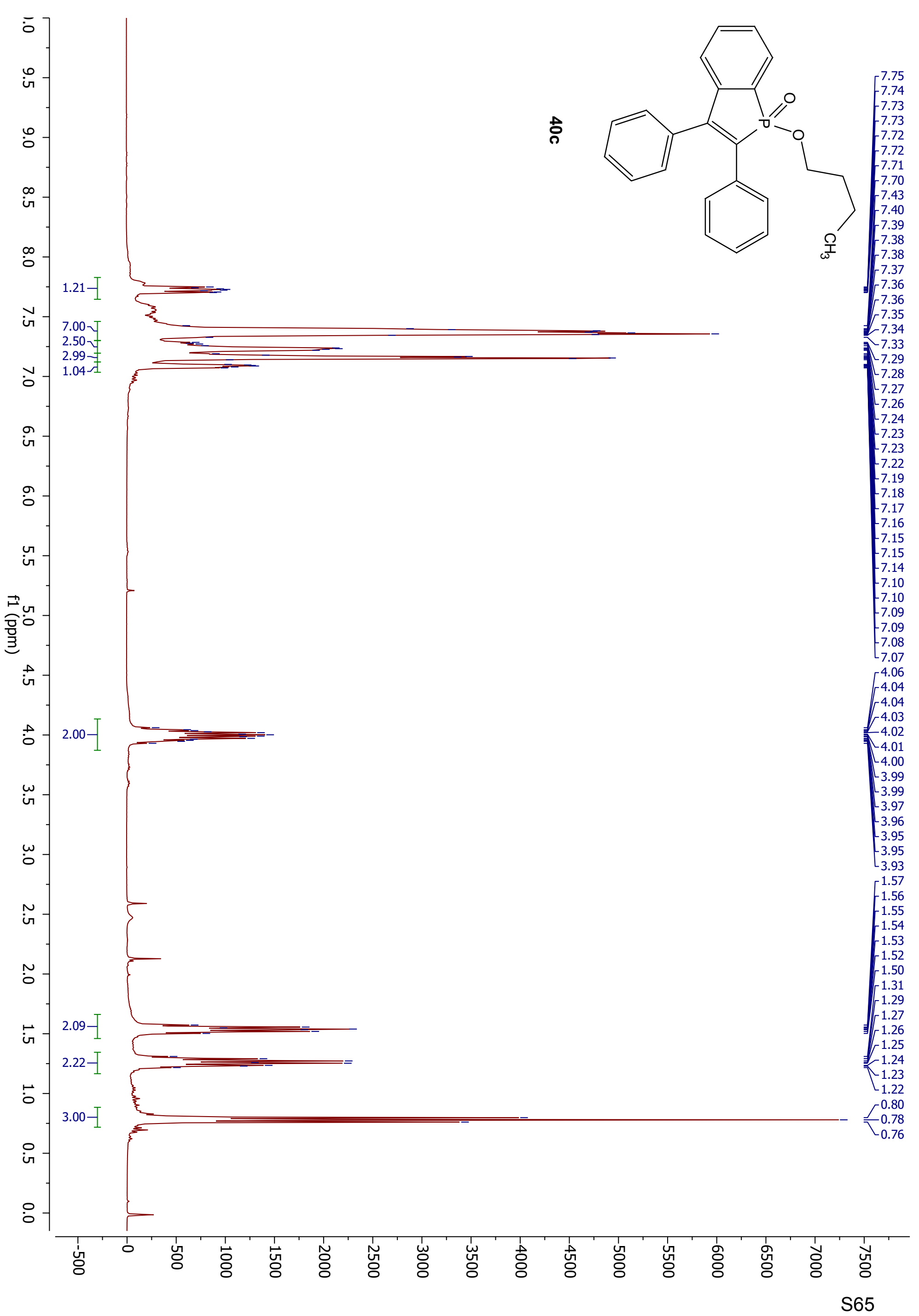




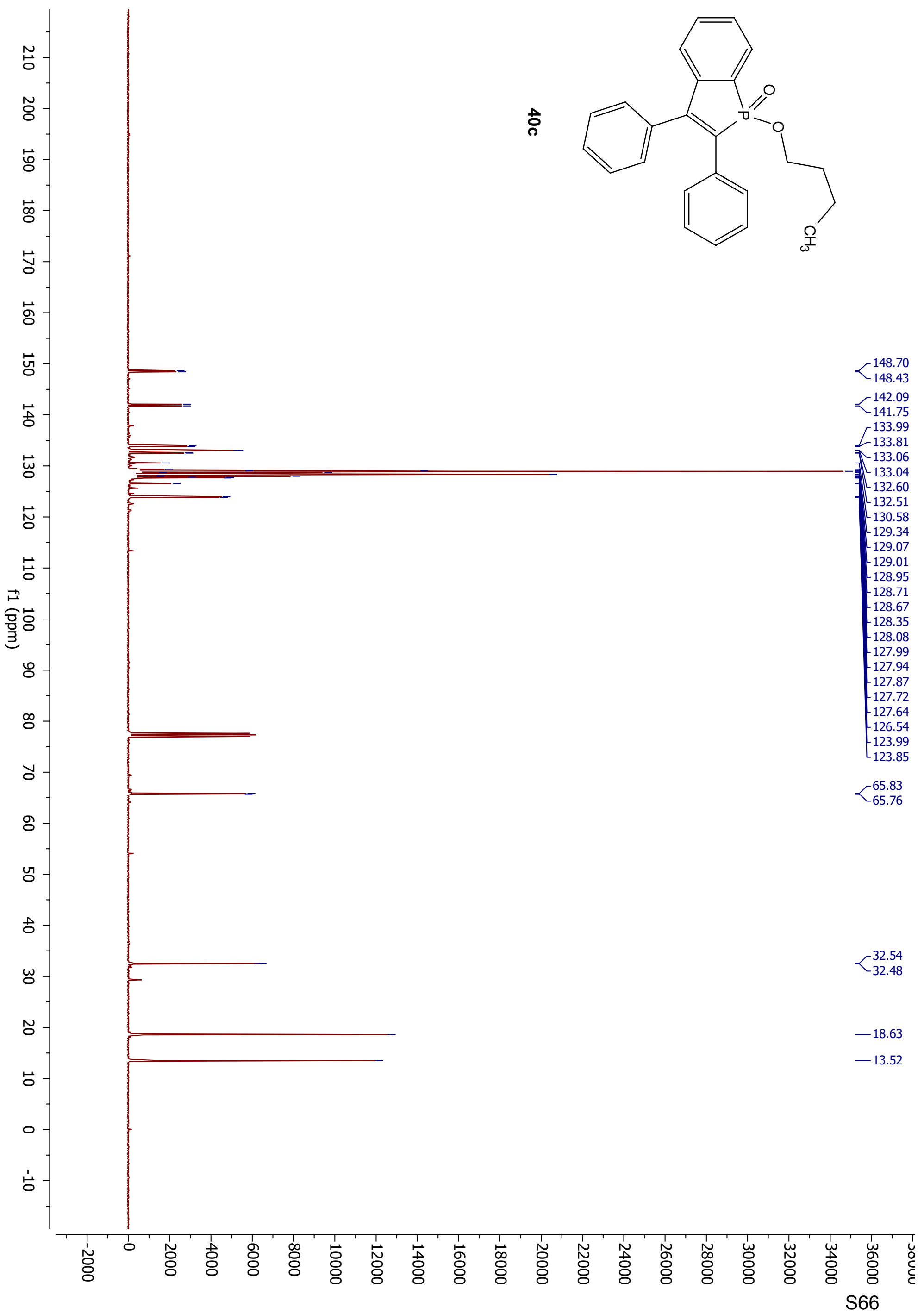



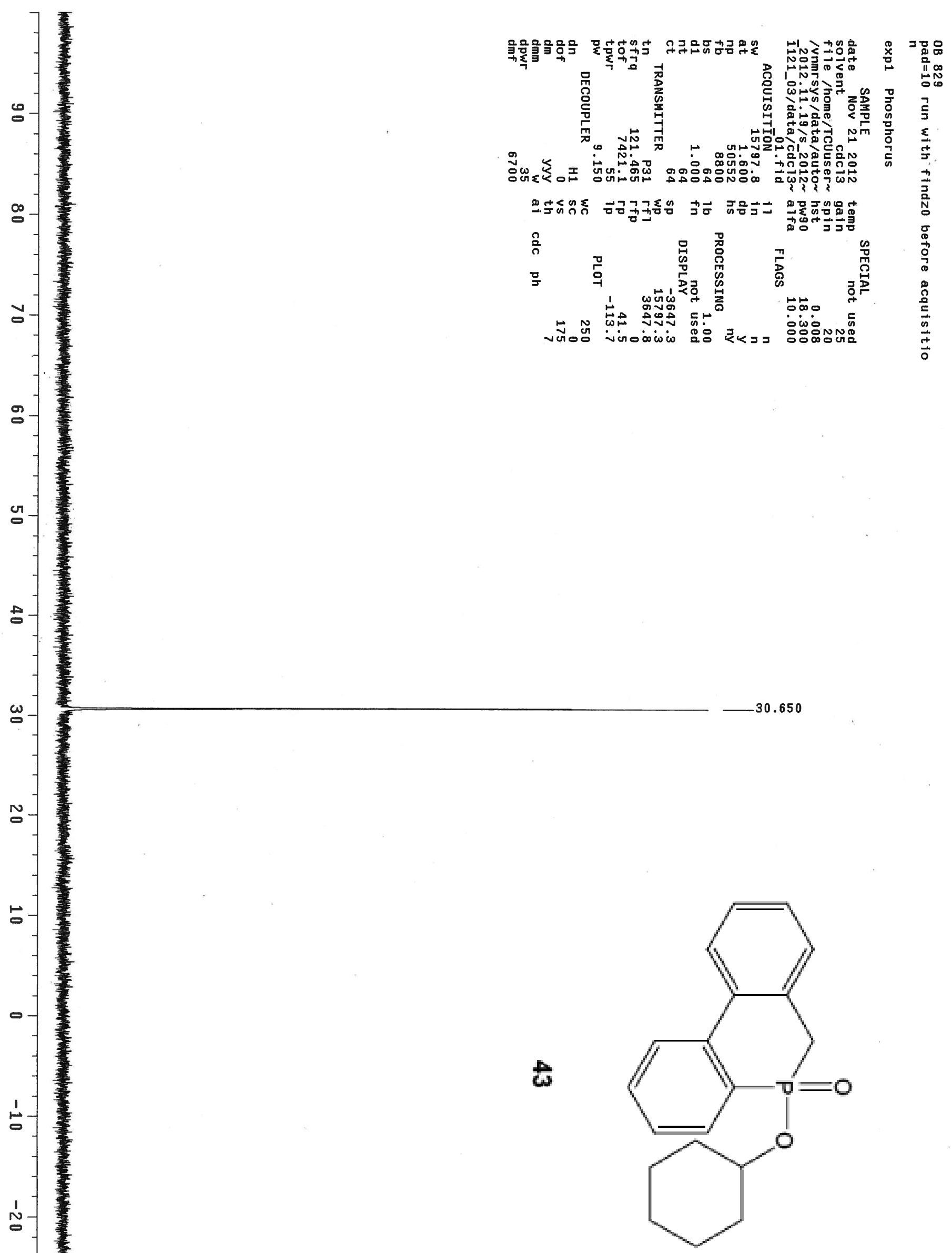

읍 

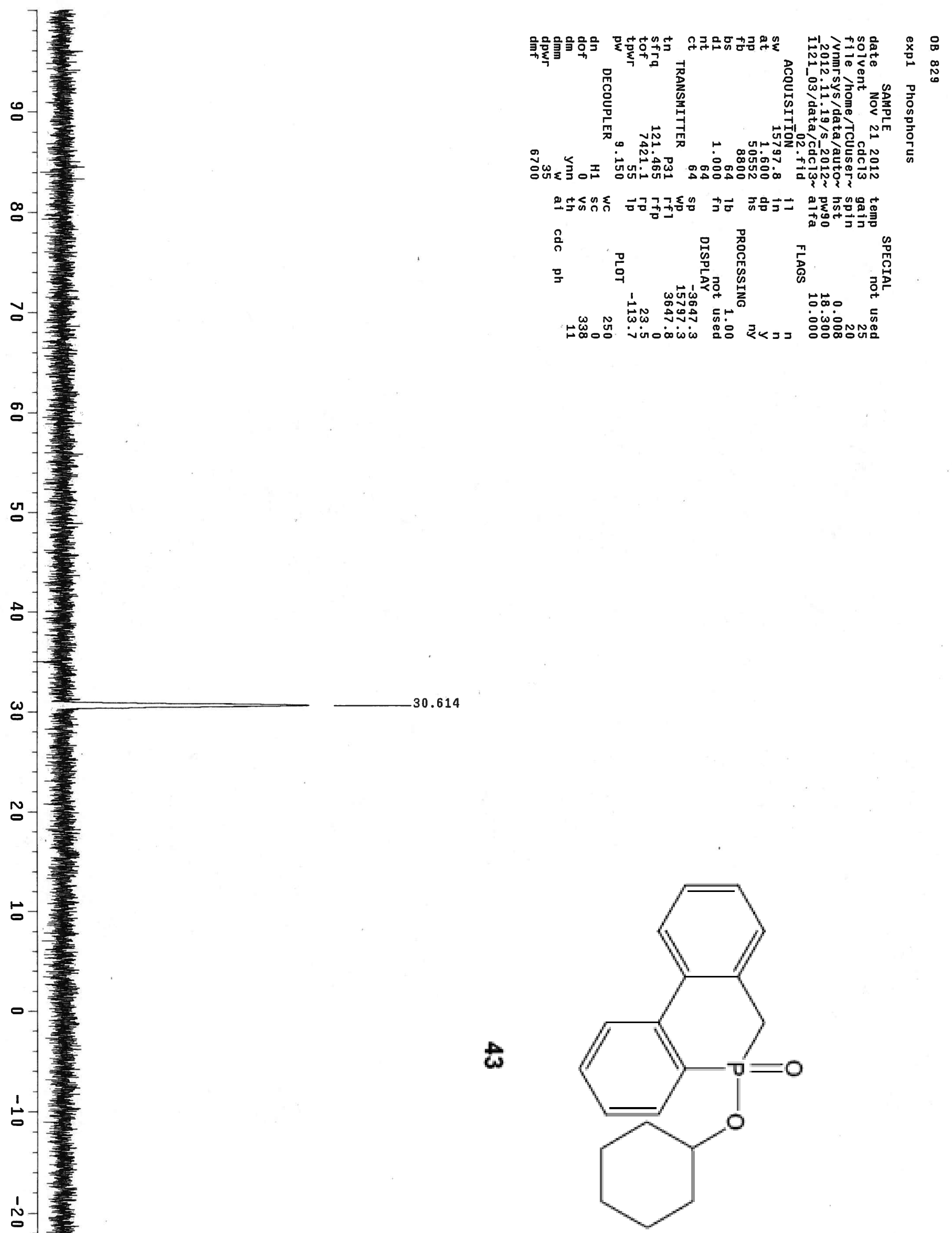


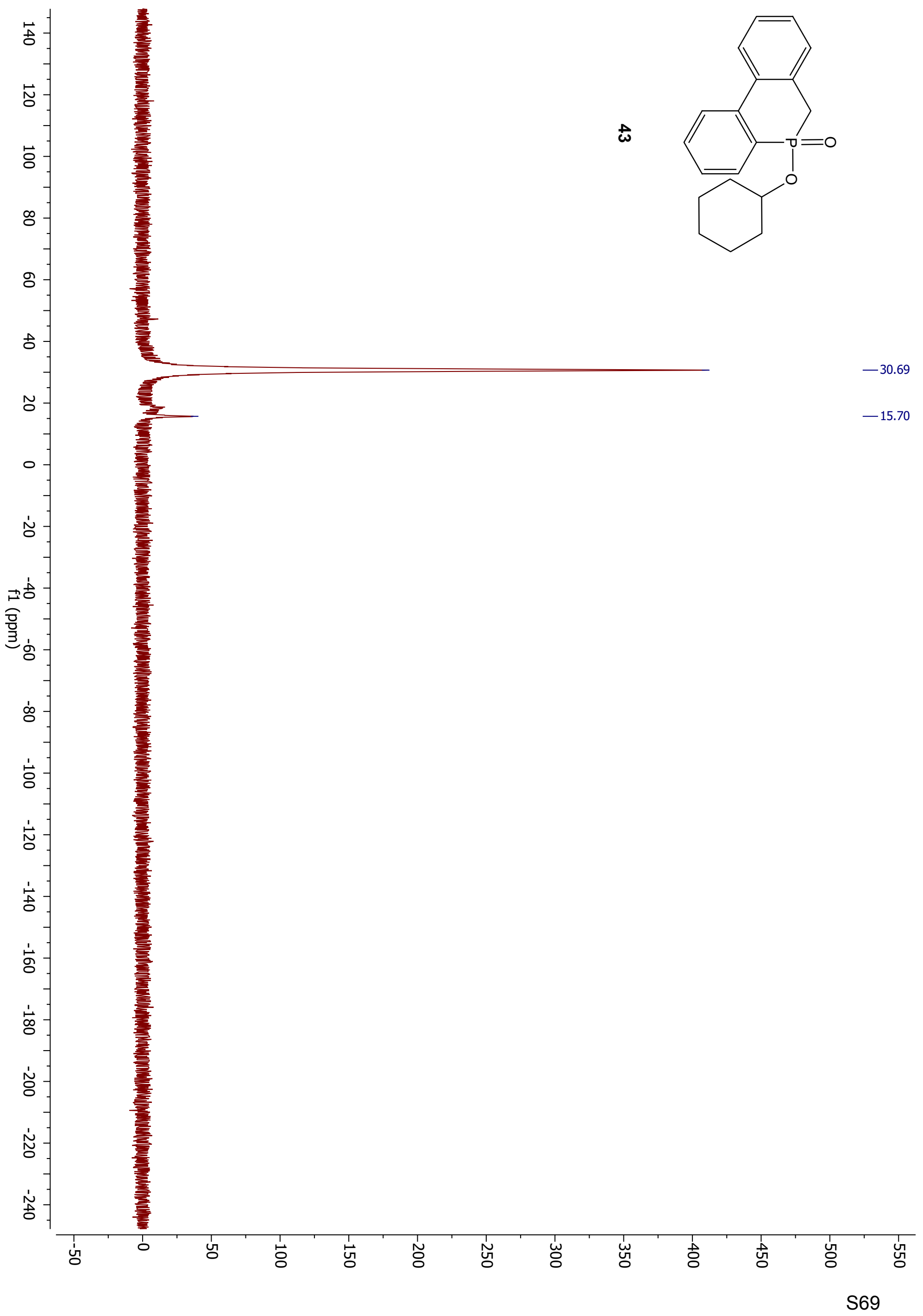




$$
\left.\right|^{3}
$$




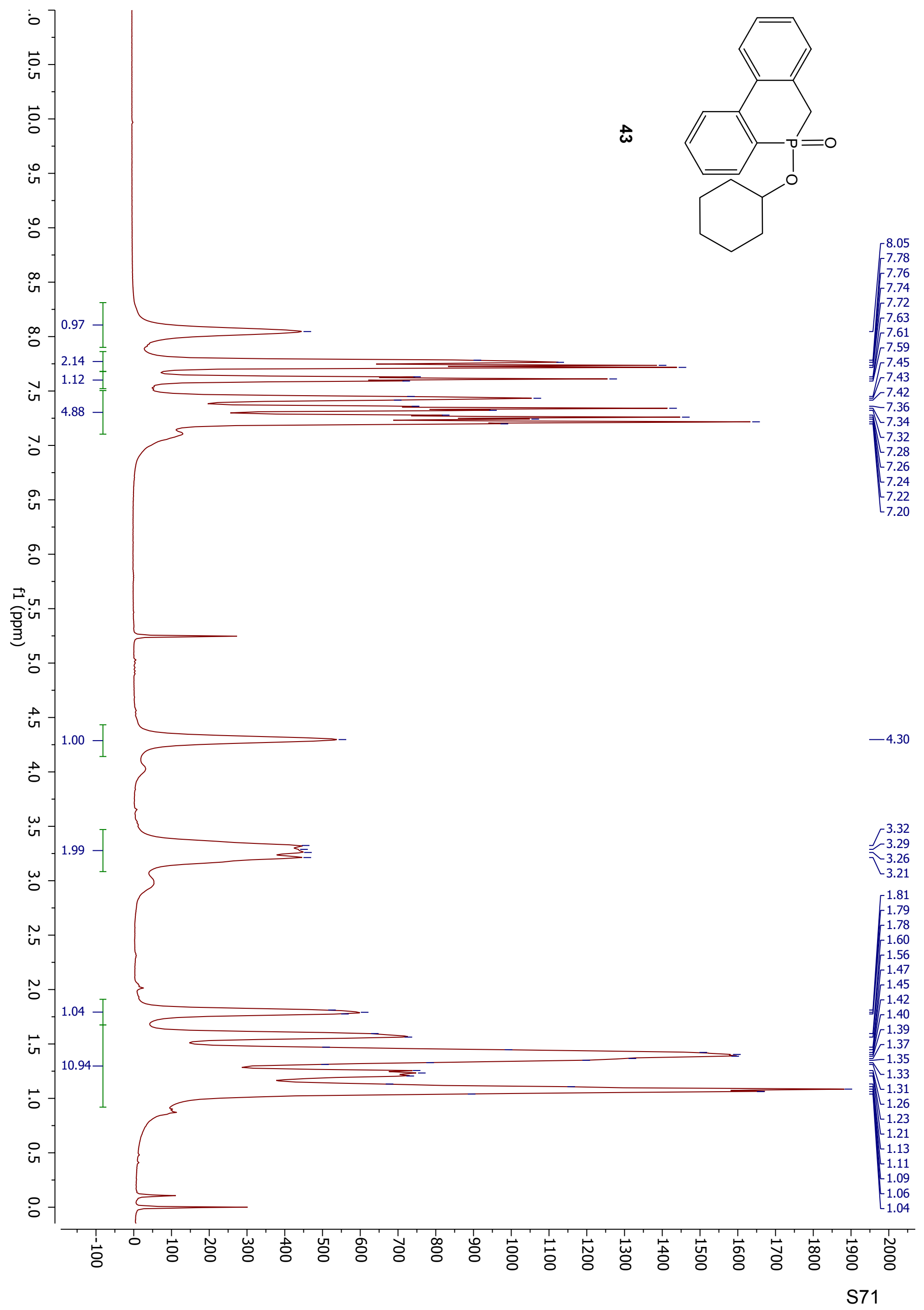




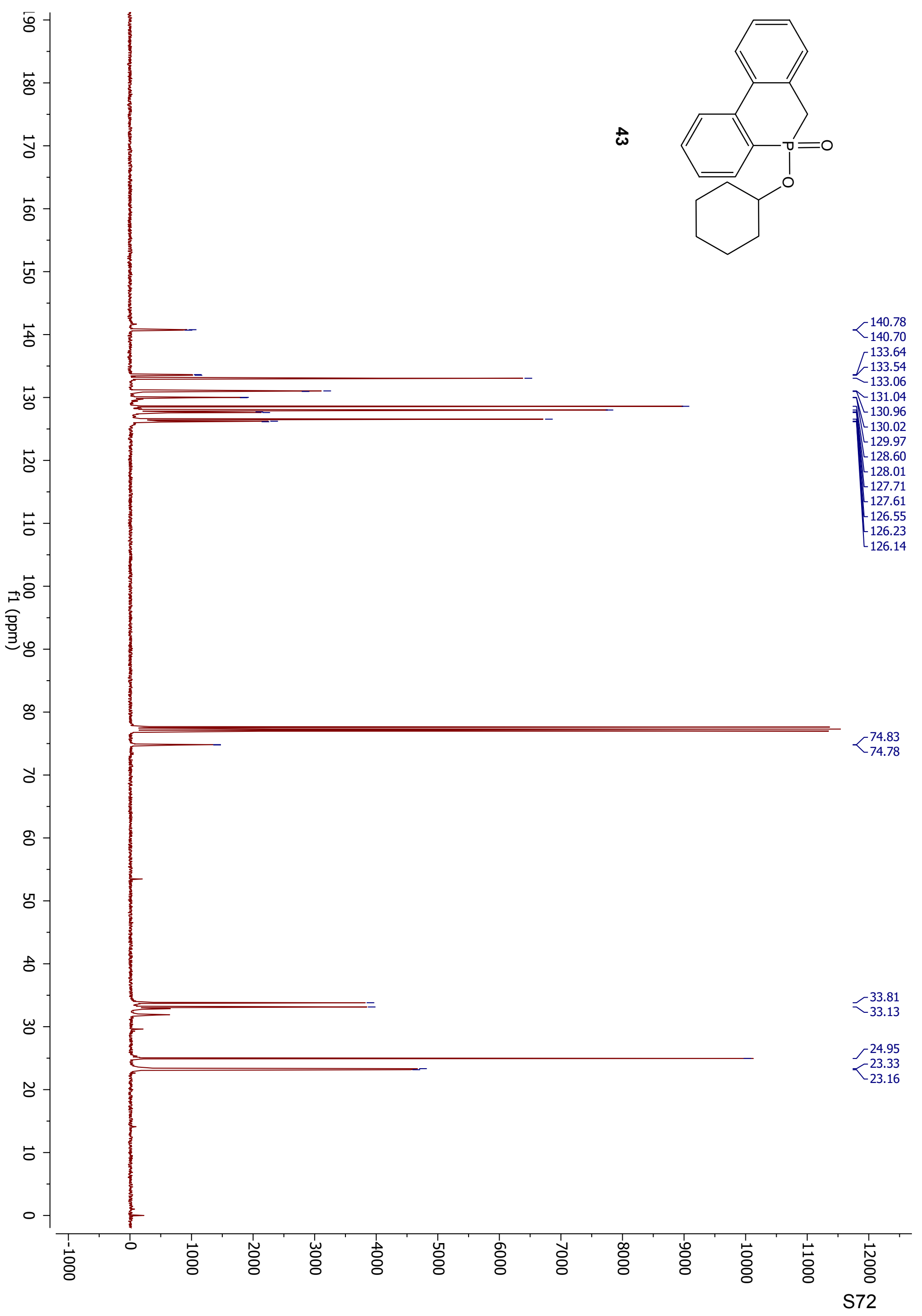




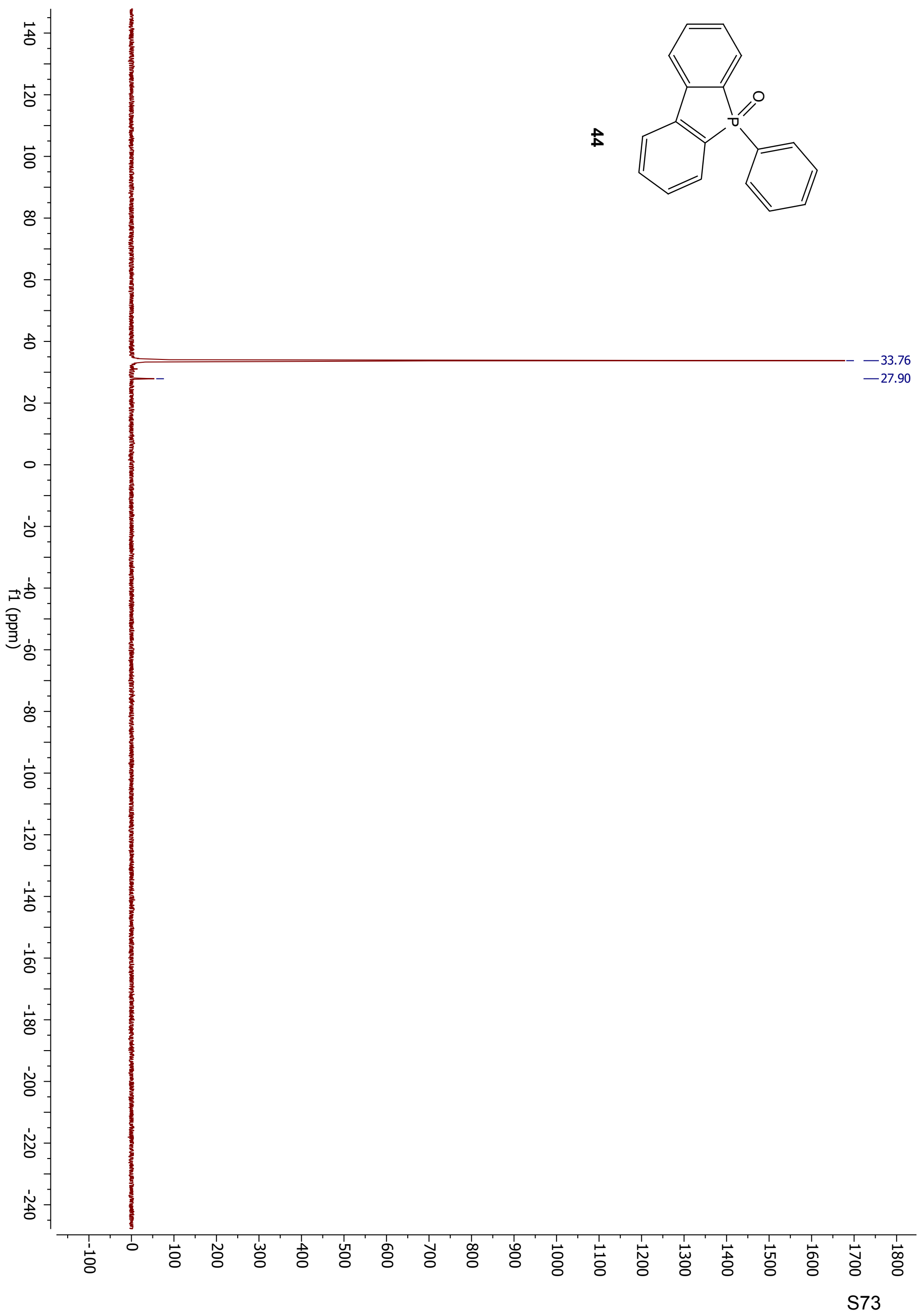




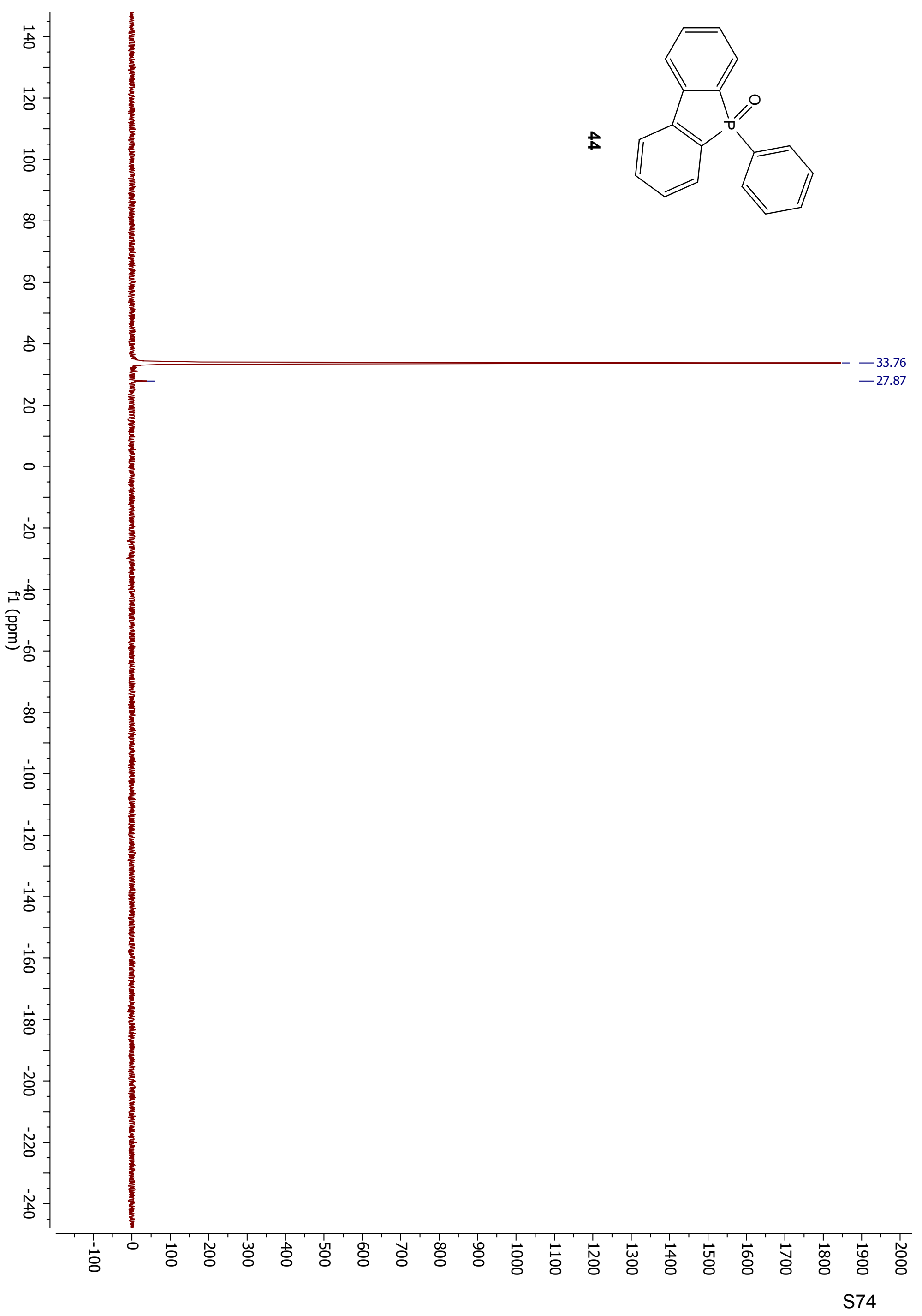




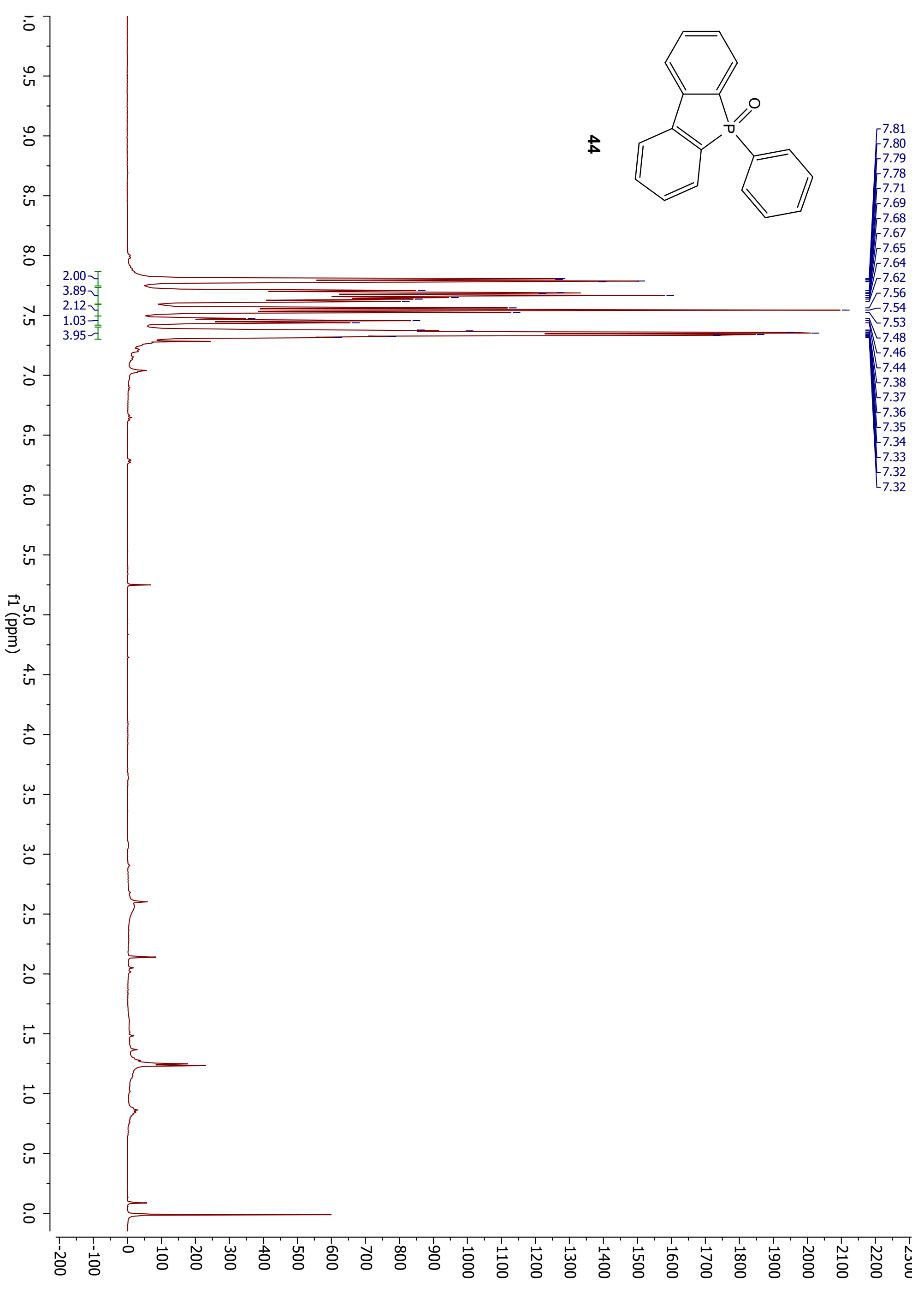




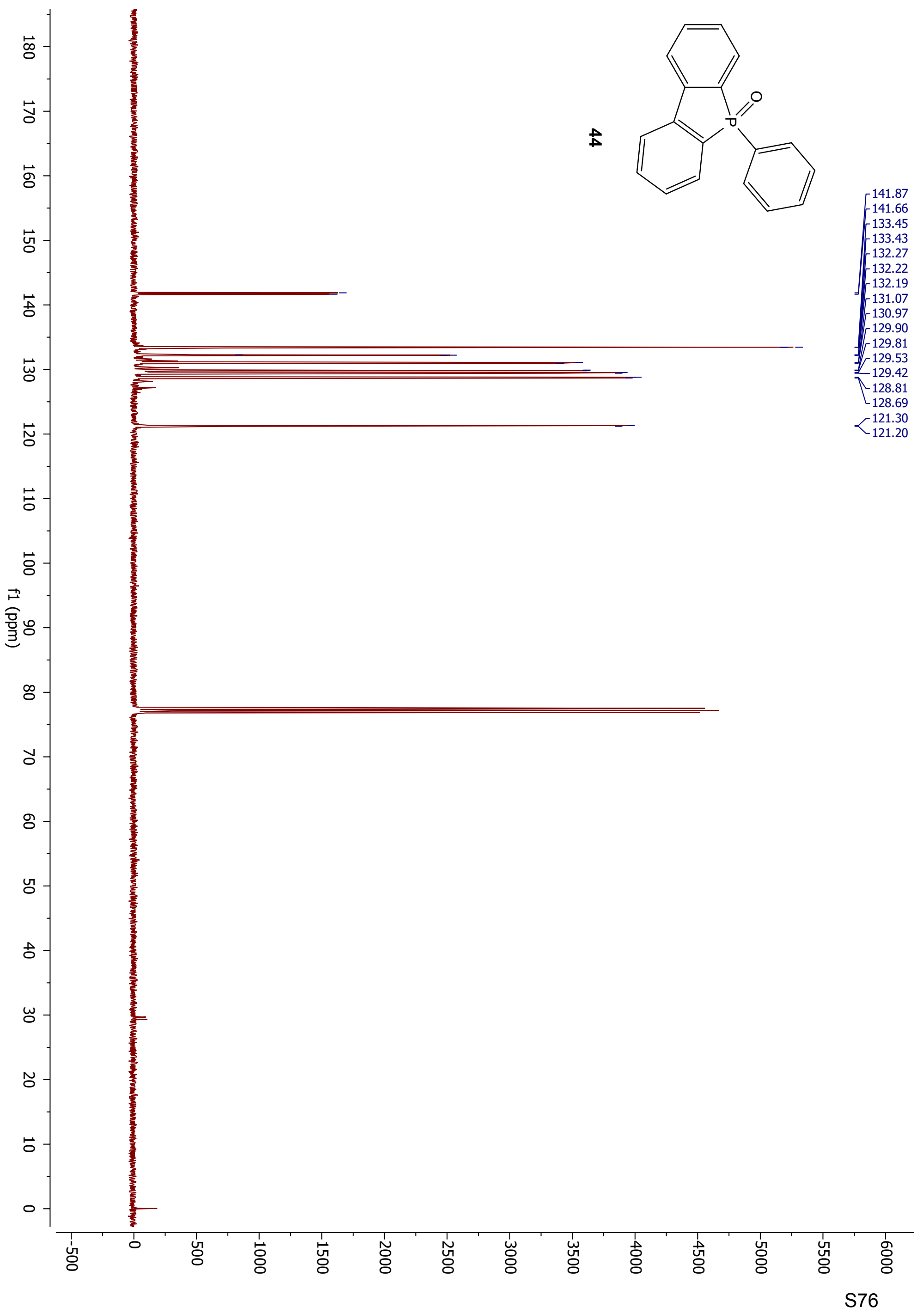




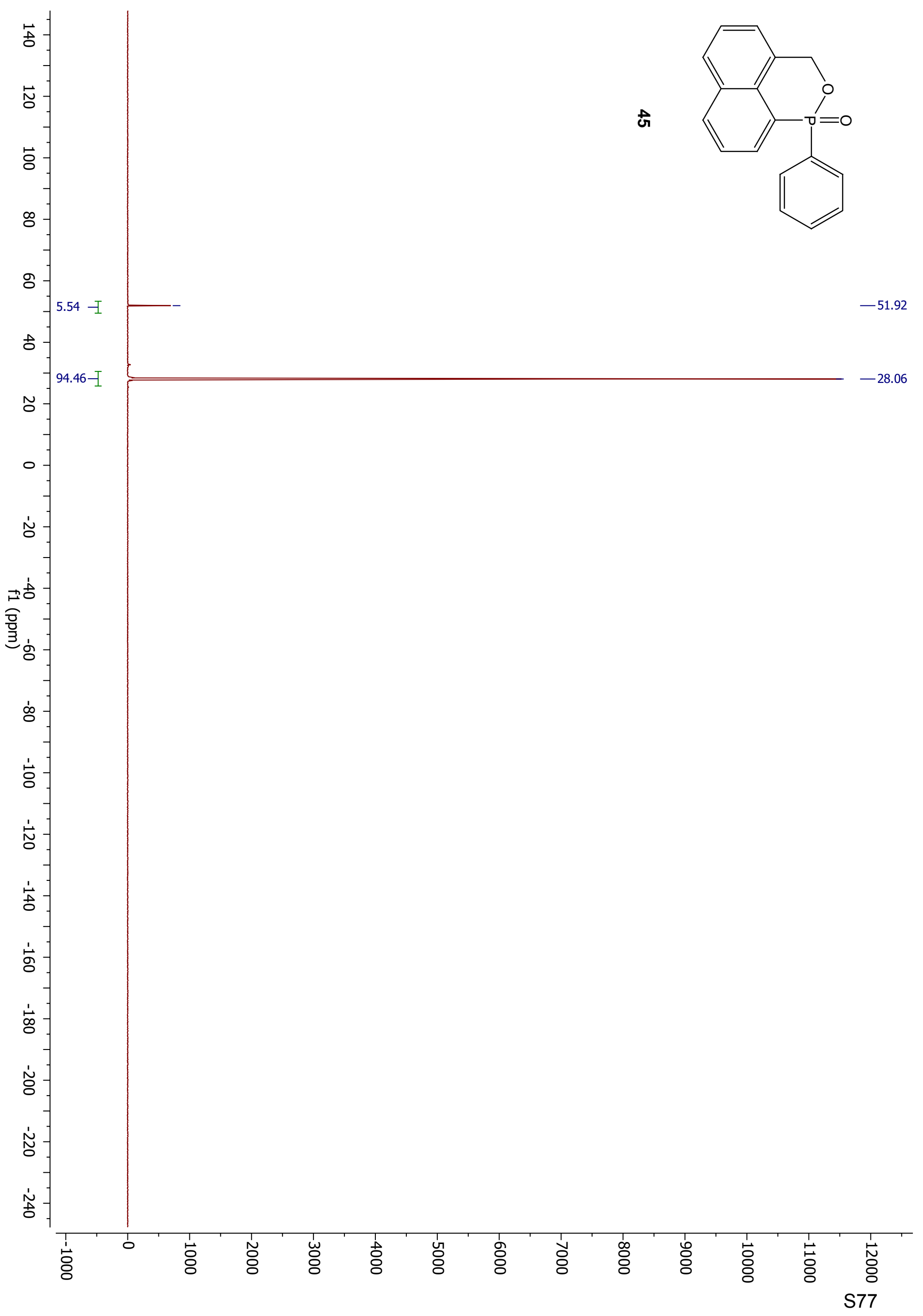




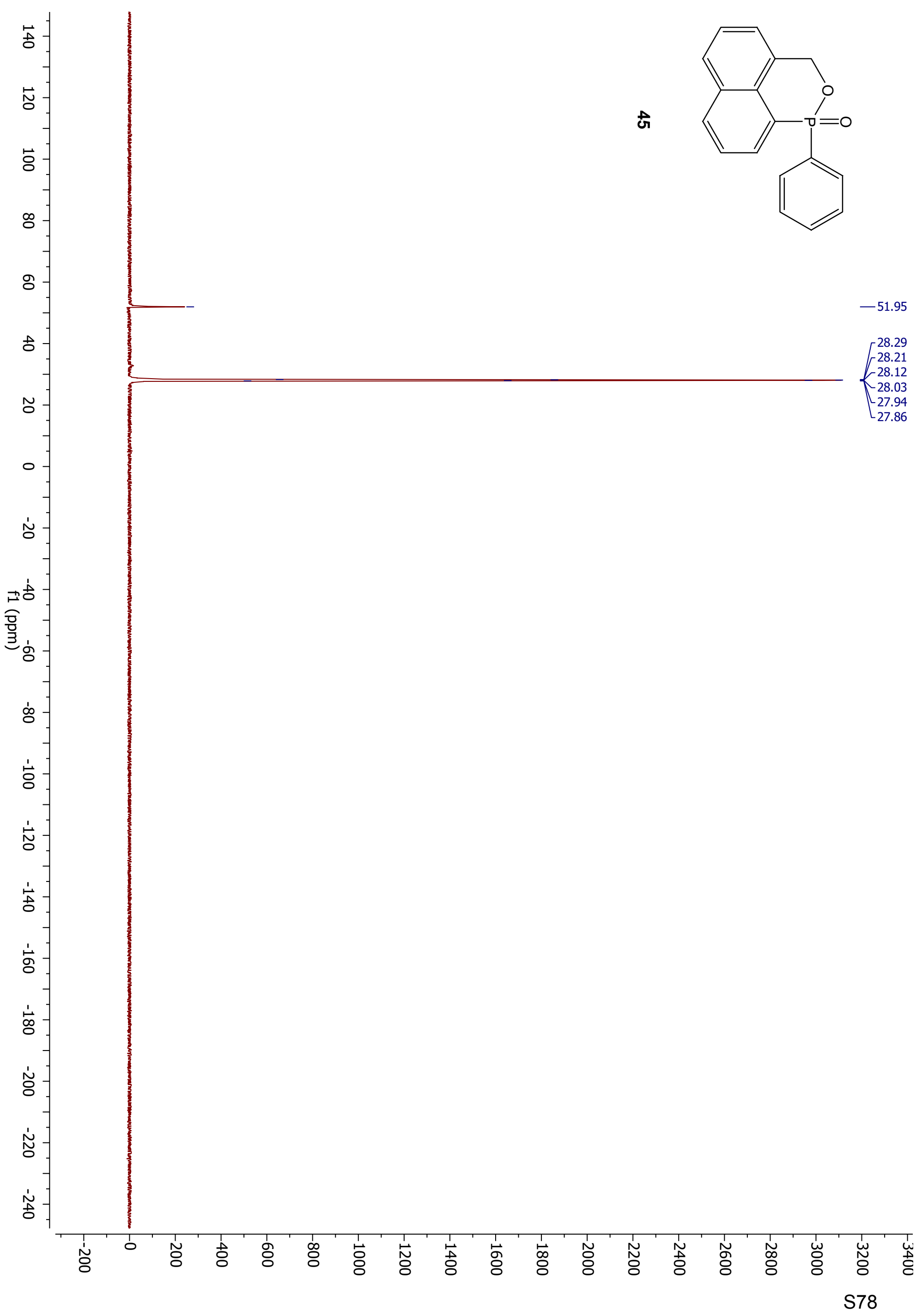




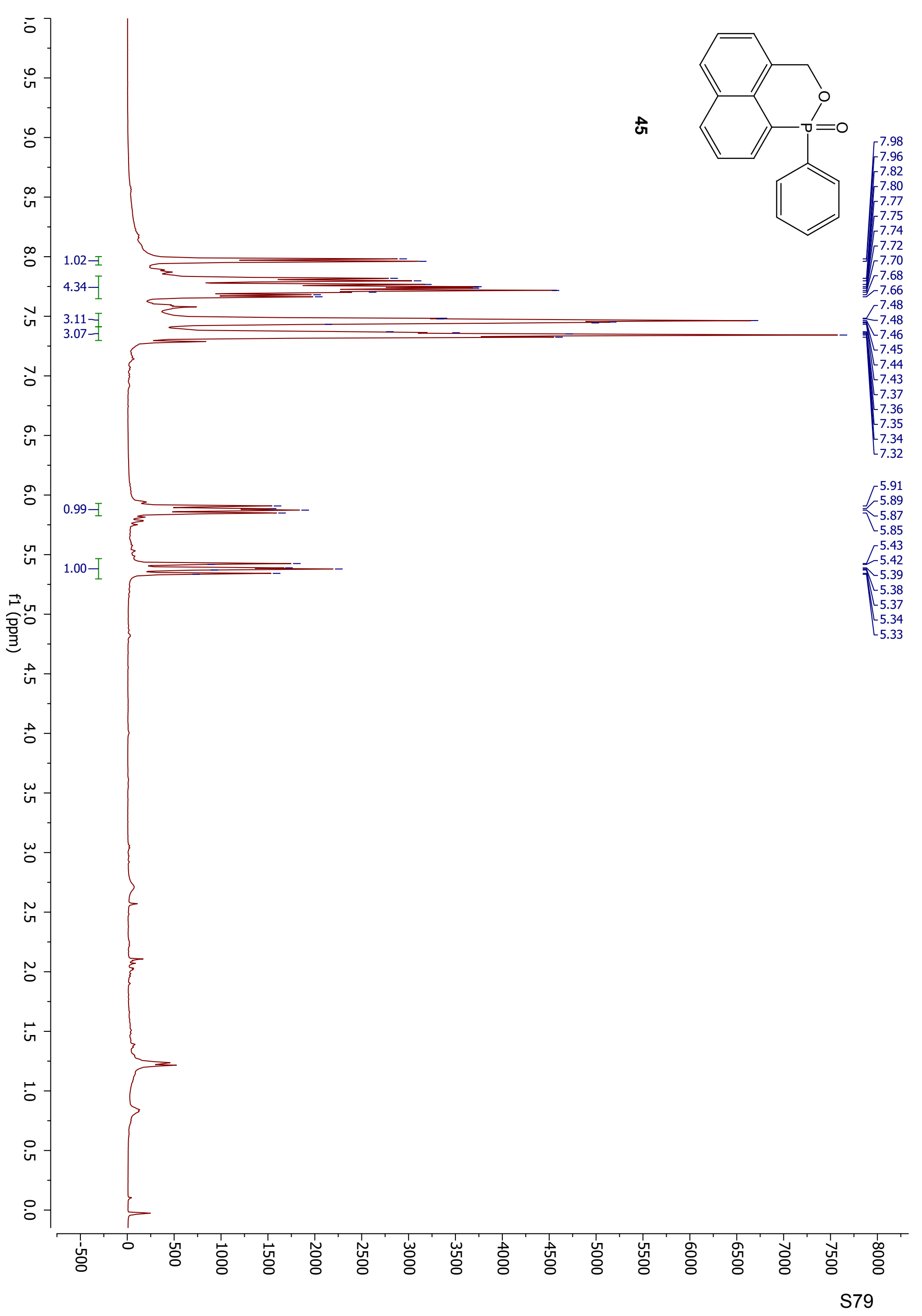




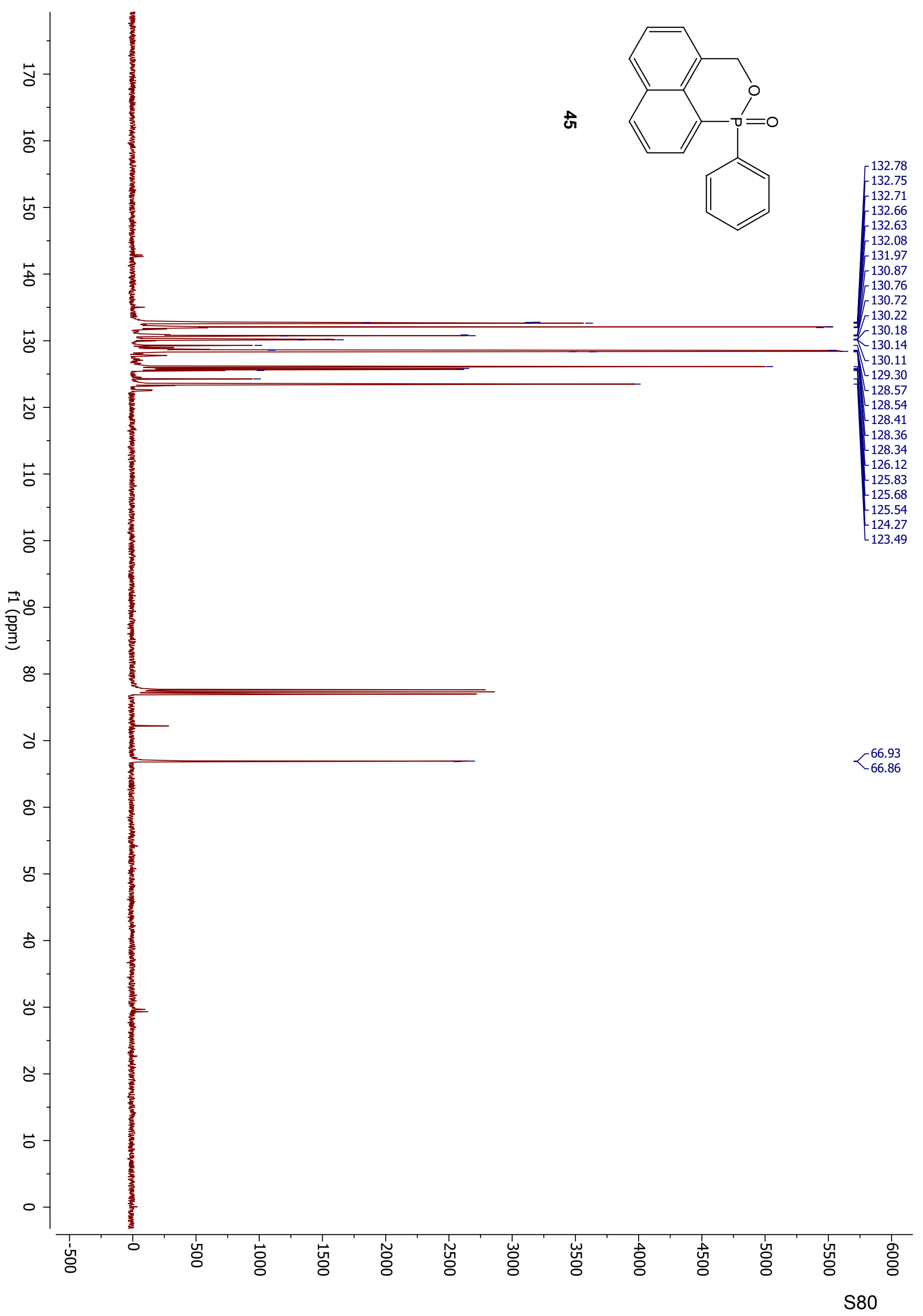




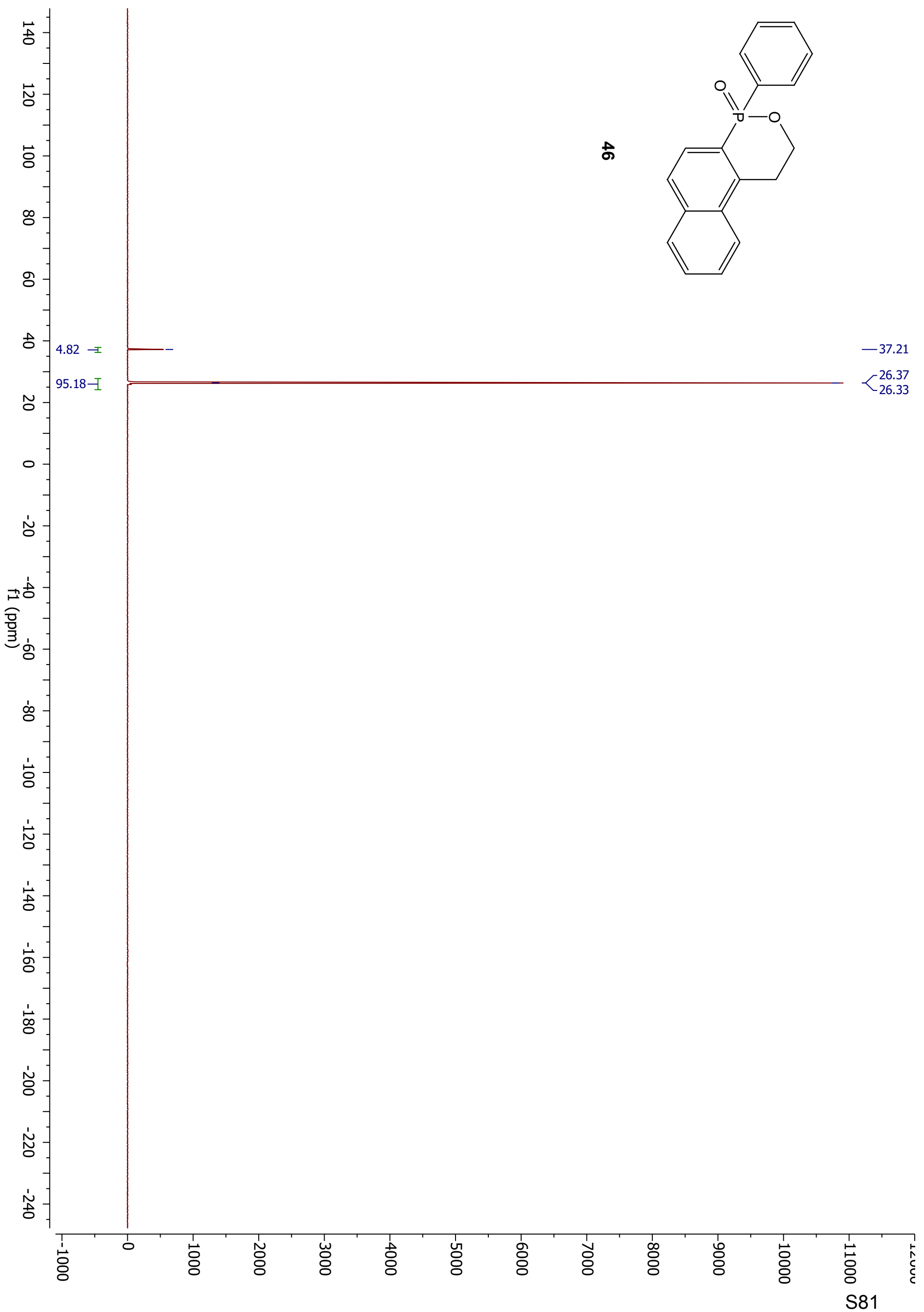




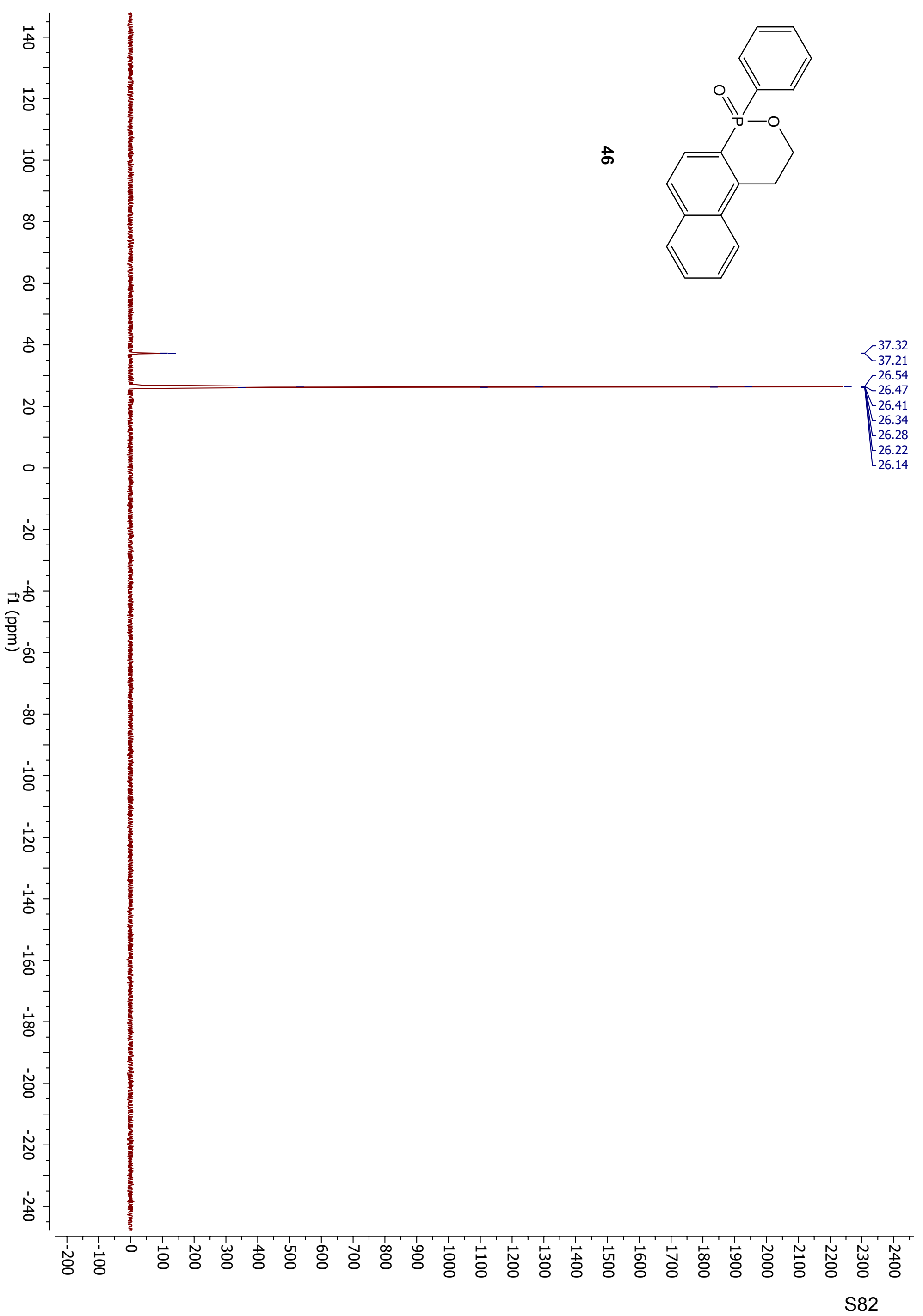




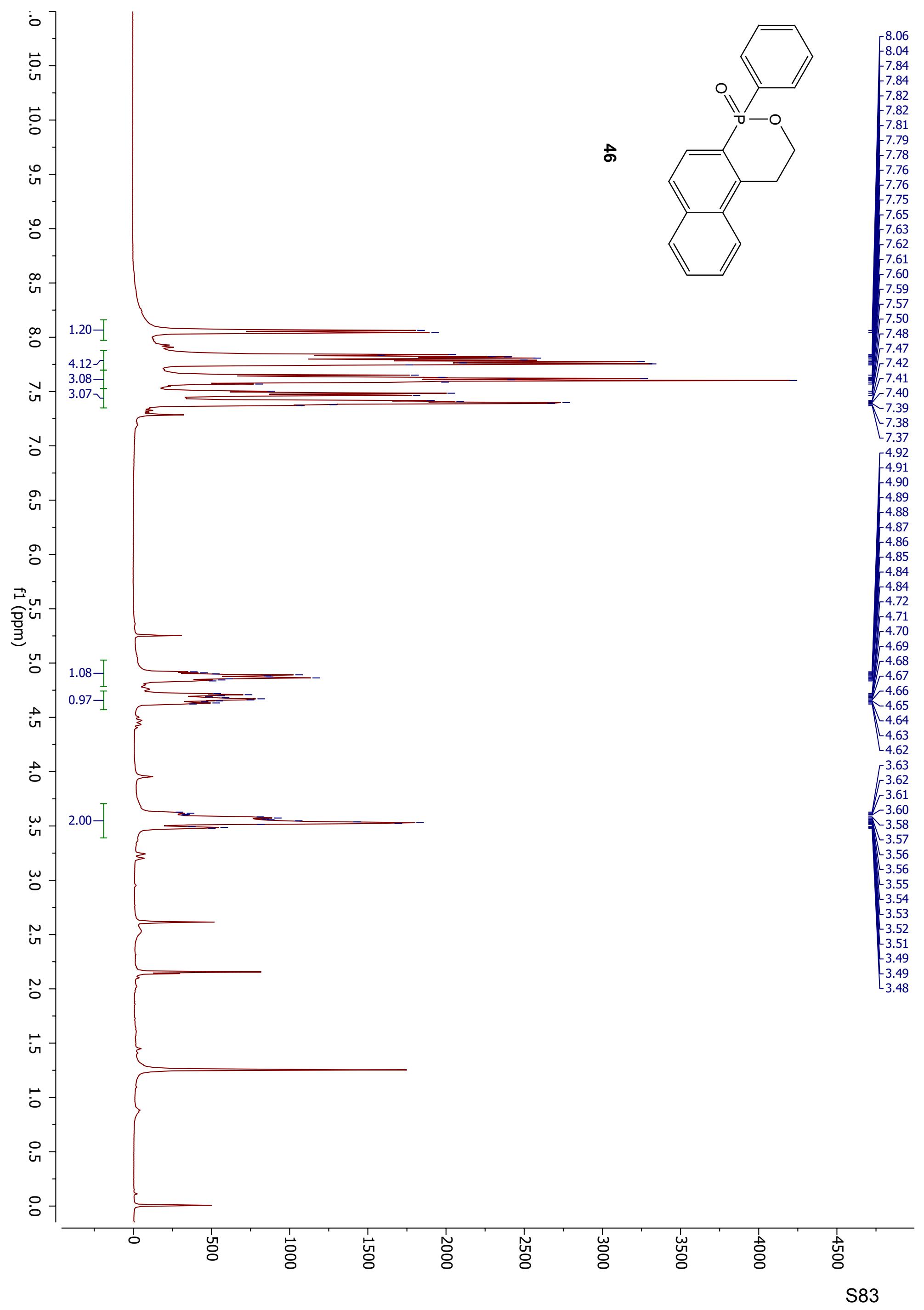




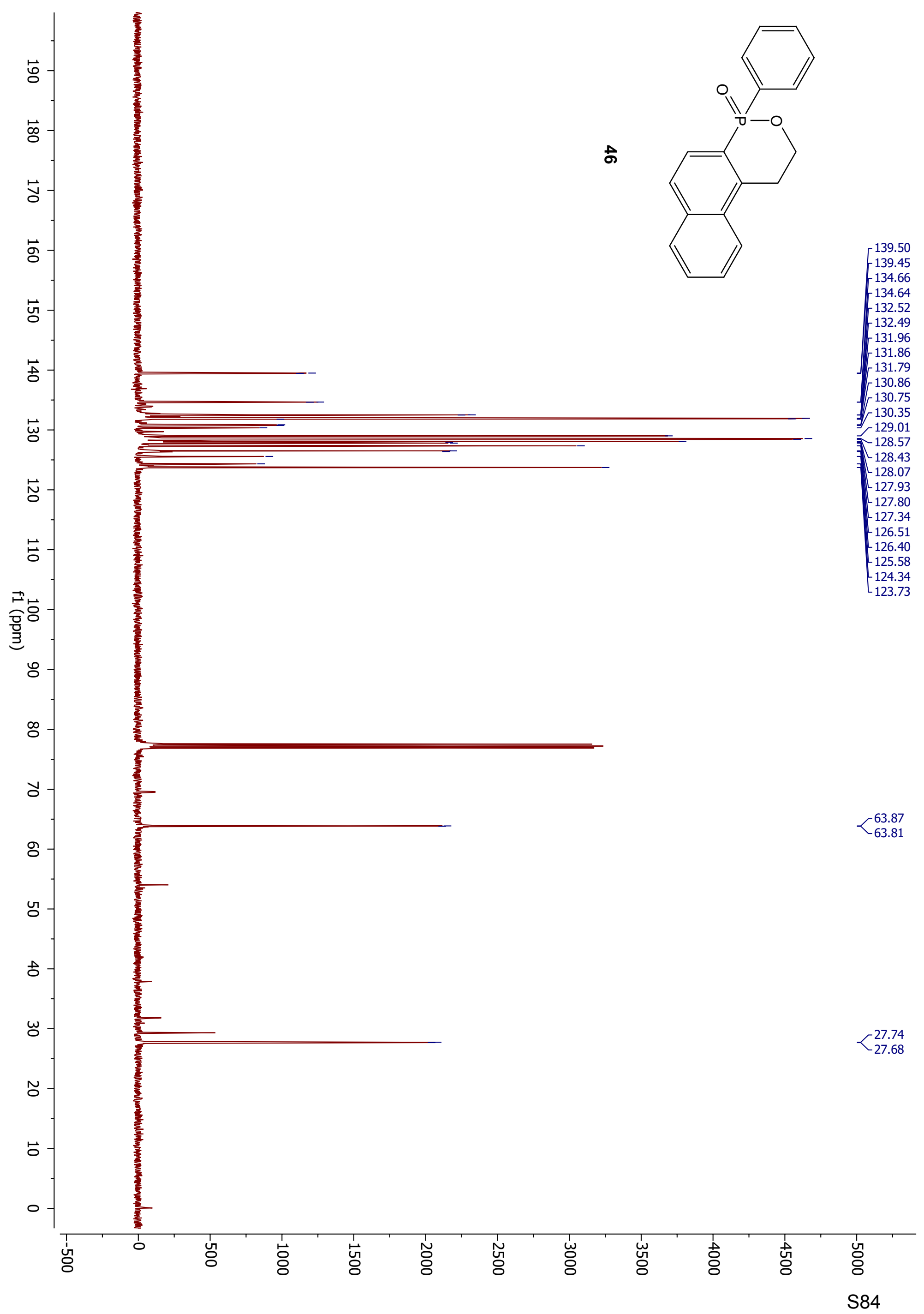




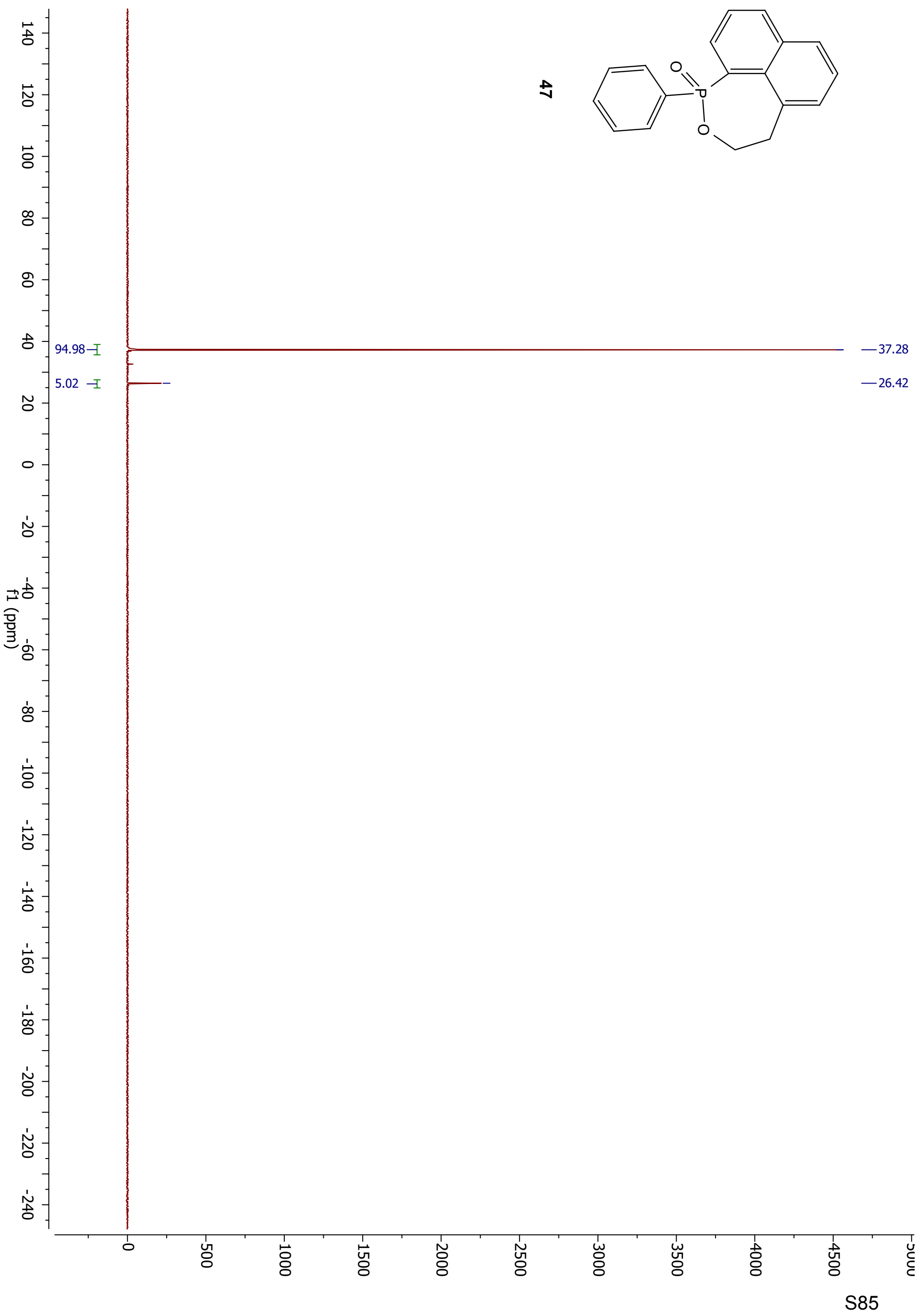




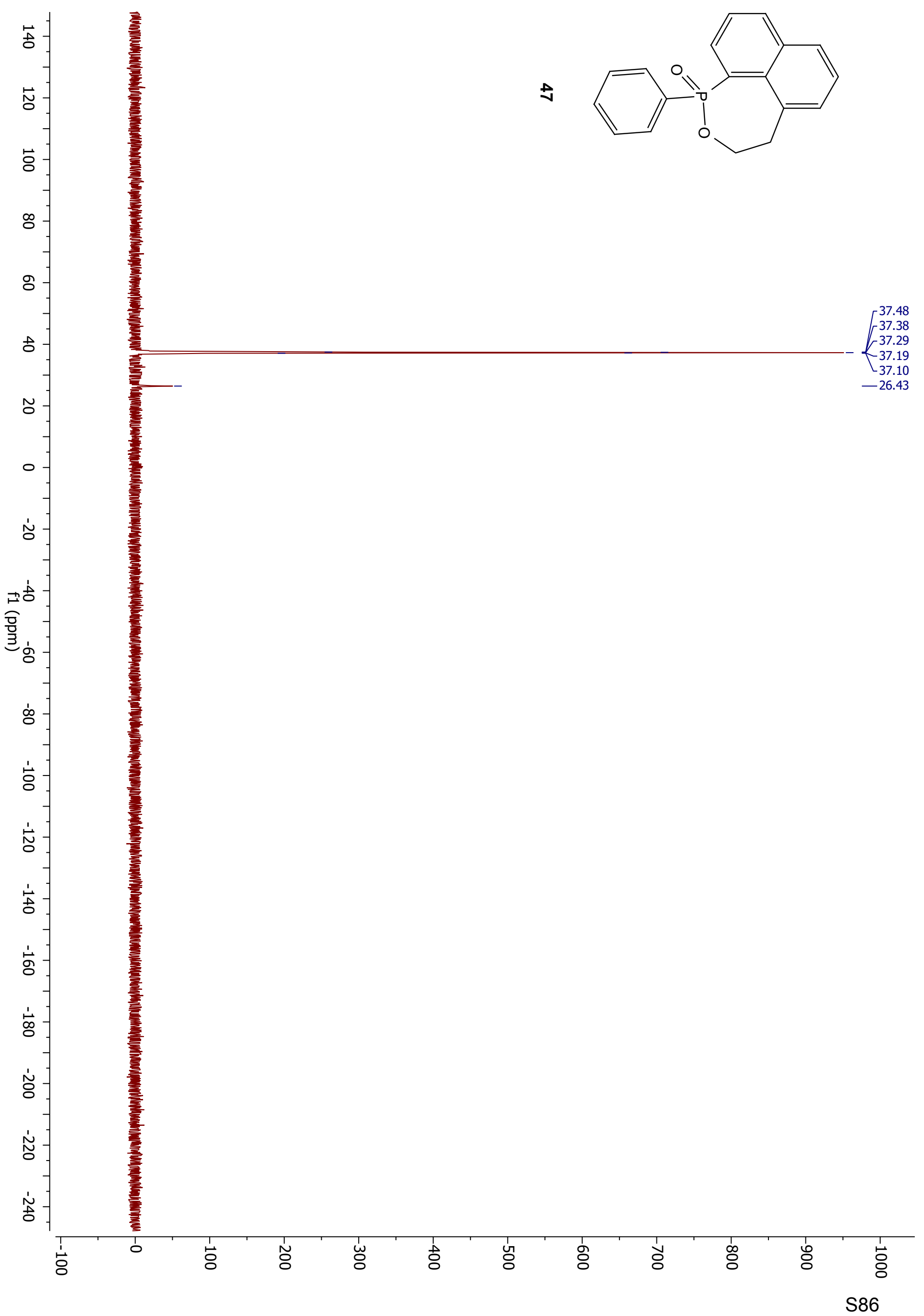




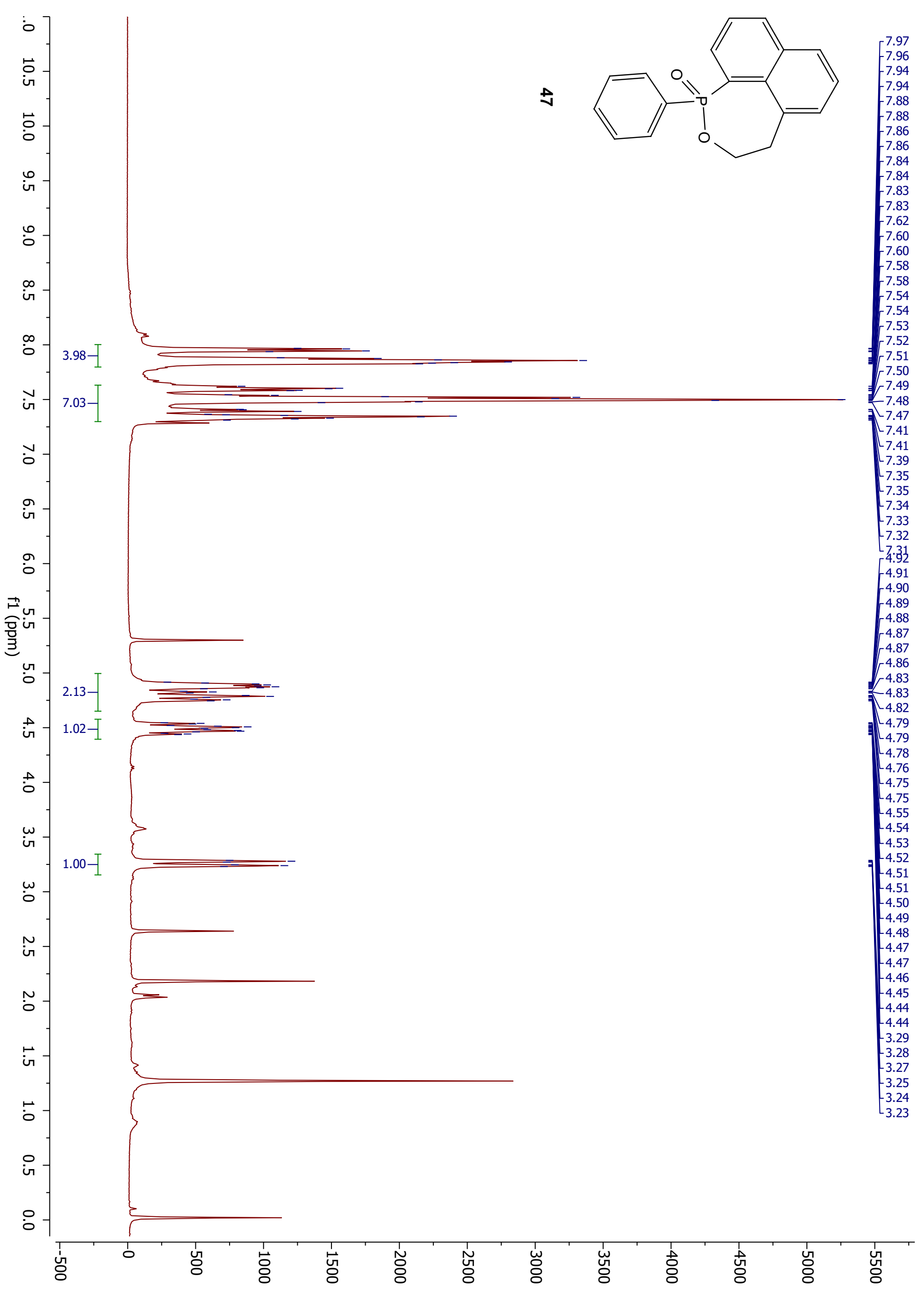




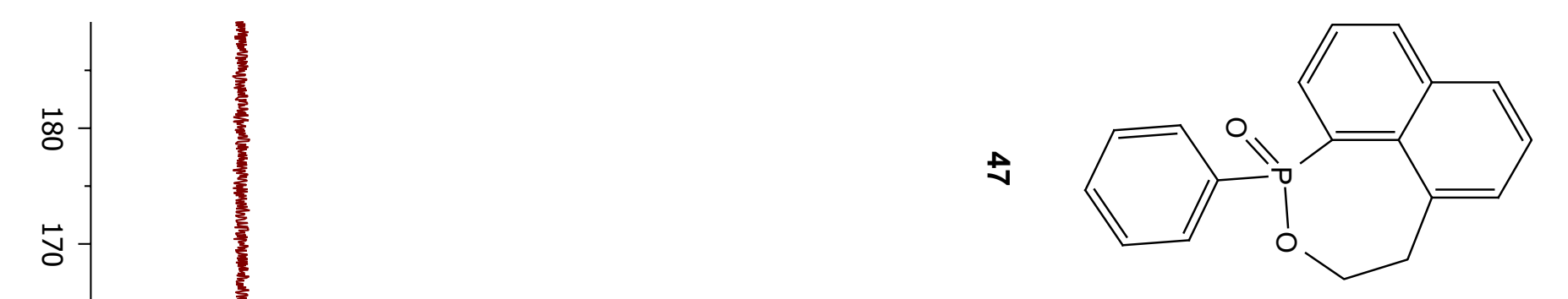

131.12

131.04

129.70

$-128.61$

$-128.59$

$-128.36$

$-128.23$

126.32

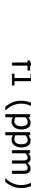

흘

$\infty$

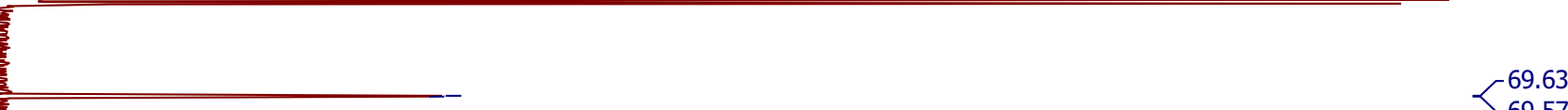

ঠ

8

응

t

然

$\omega$

$\approx$

เ

$\circ$

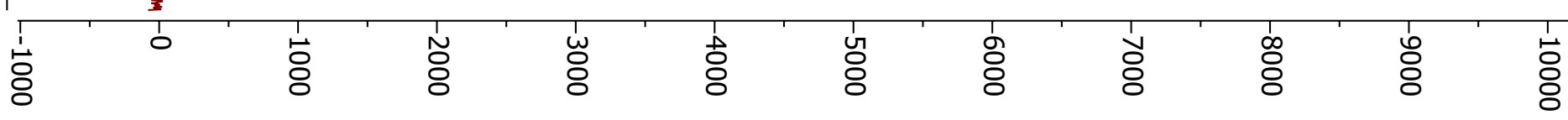




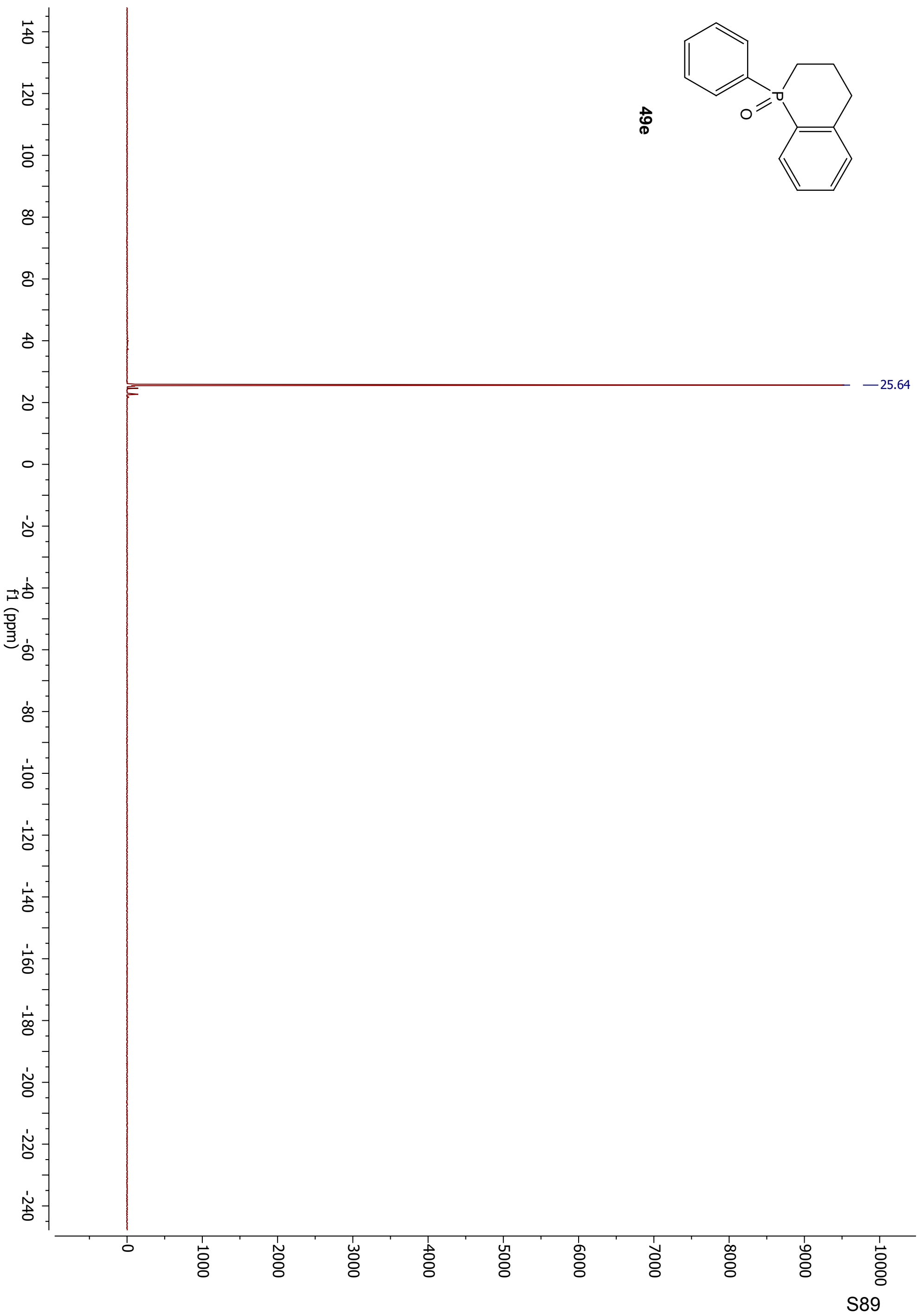




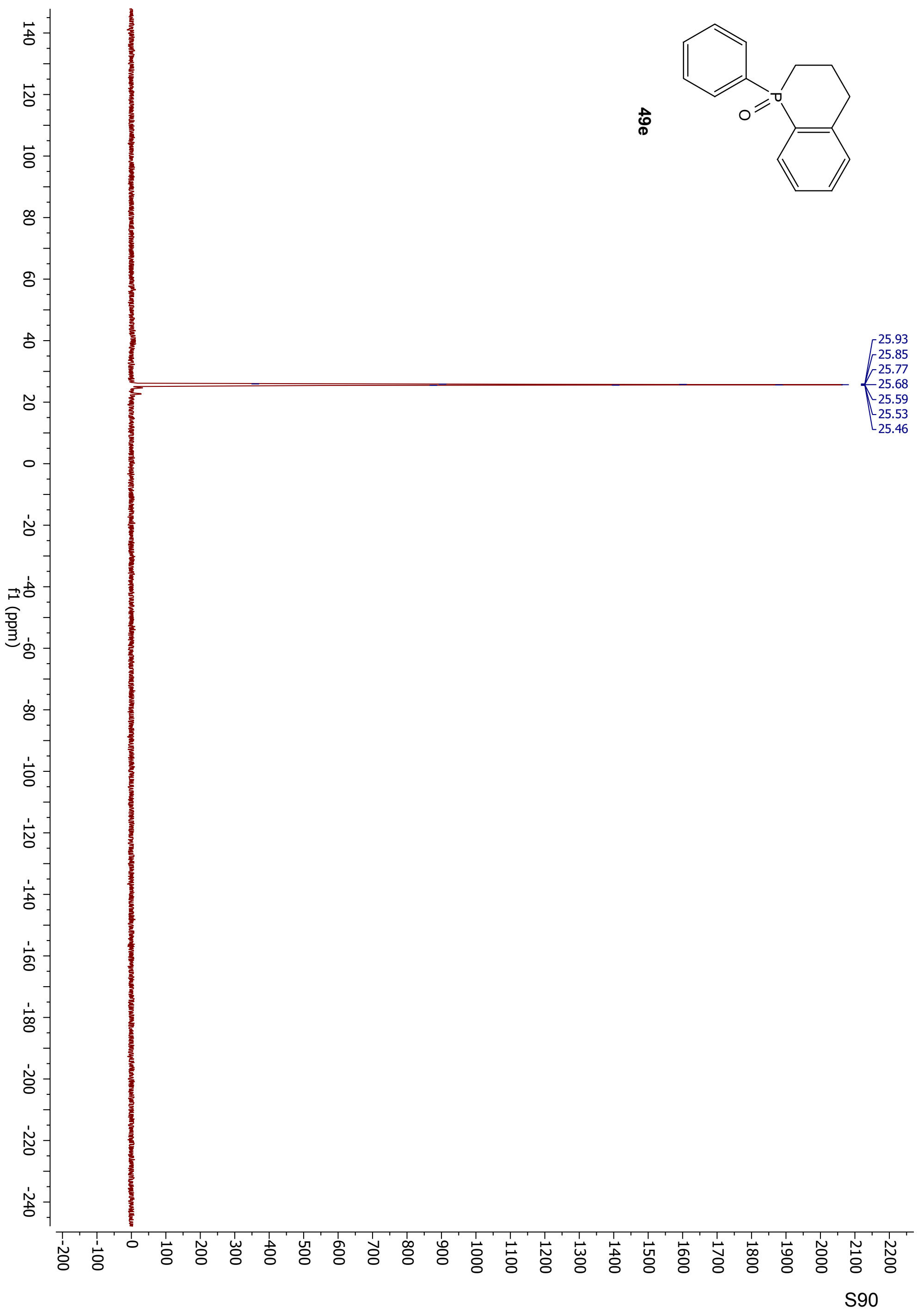




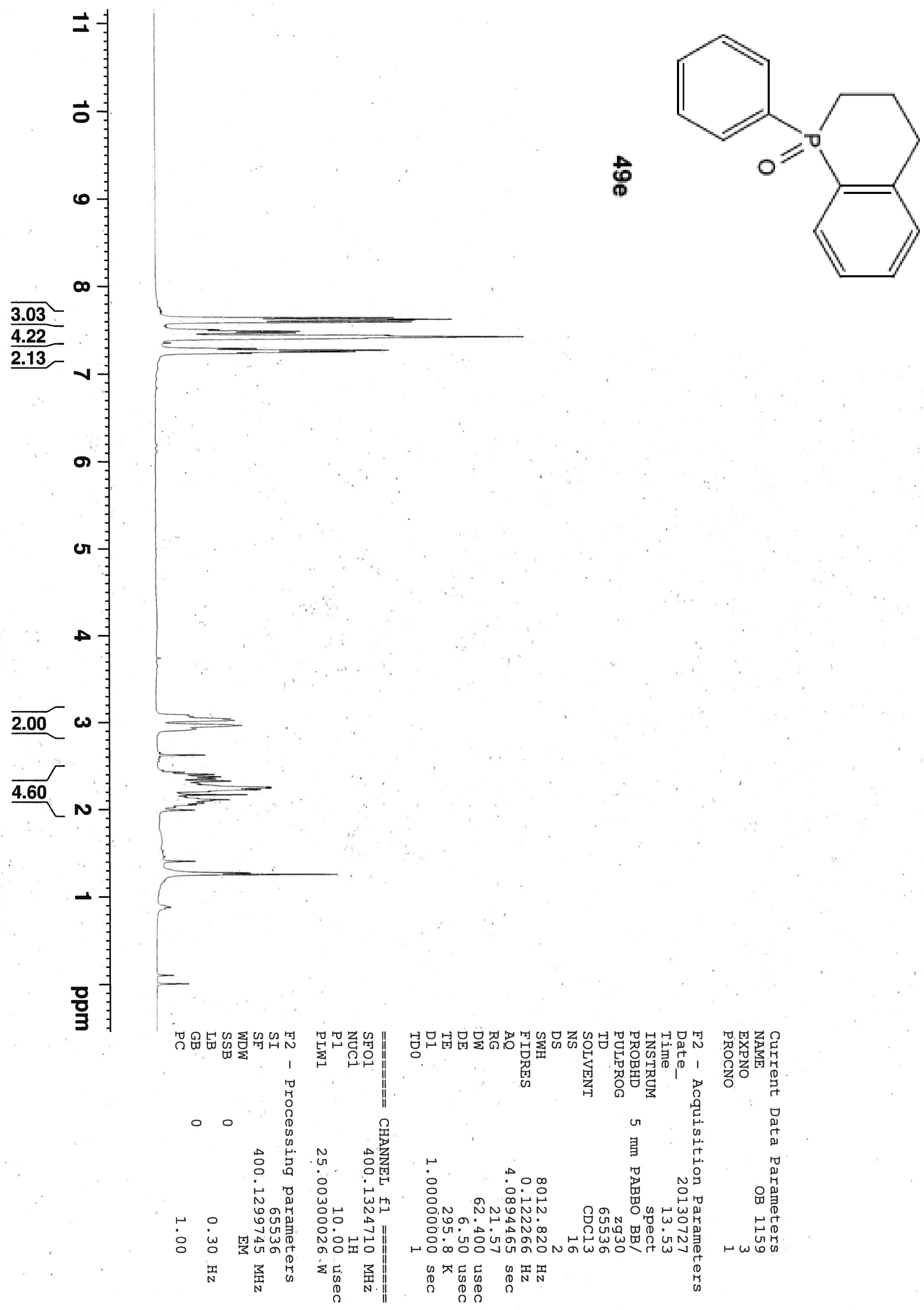




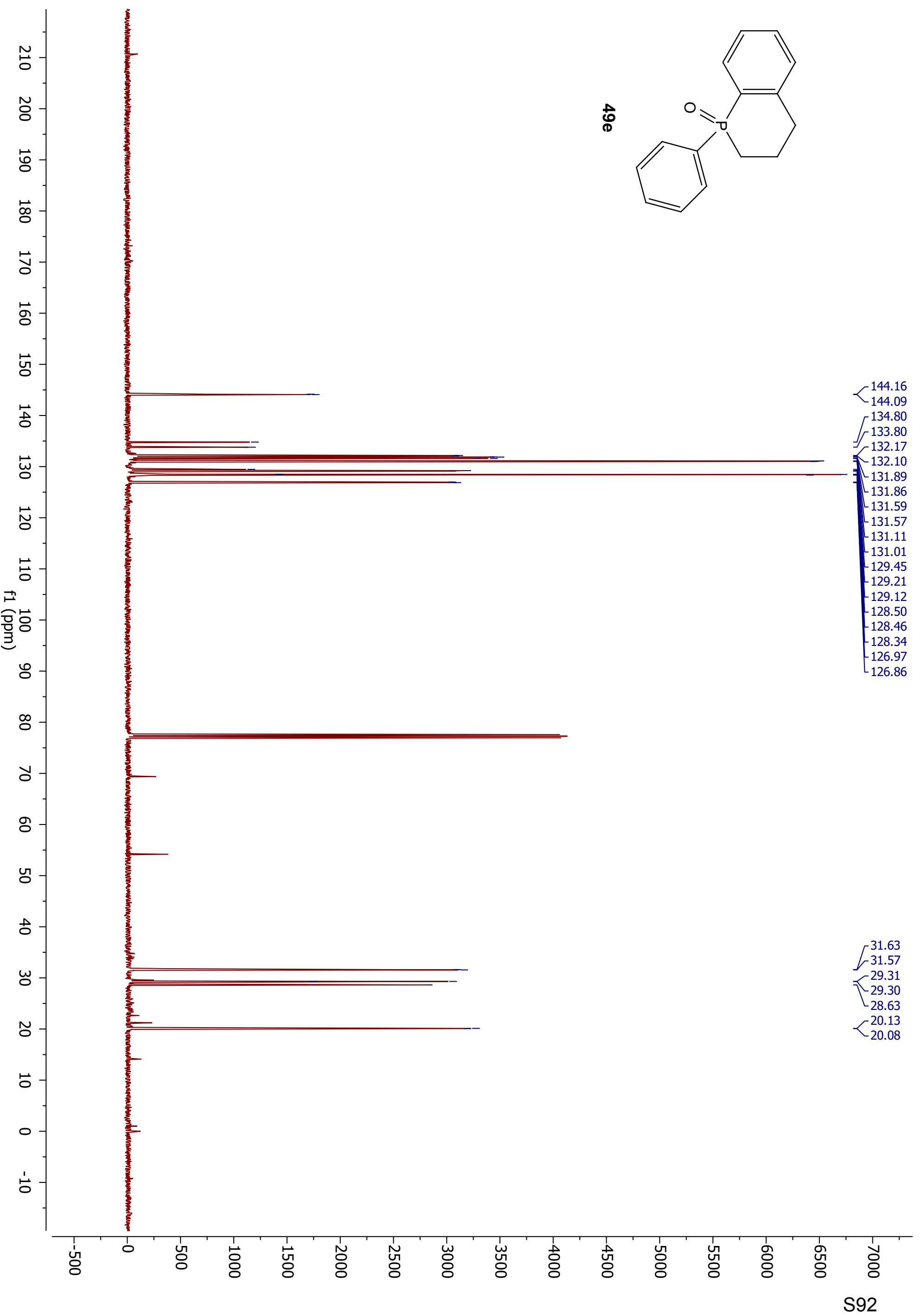




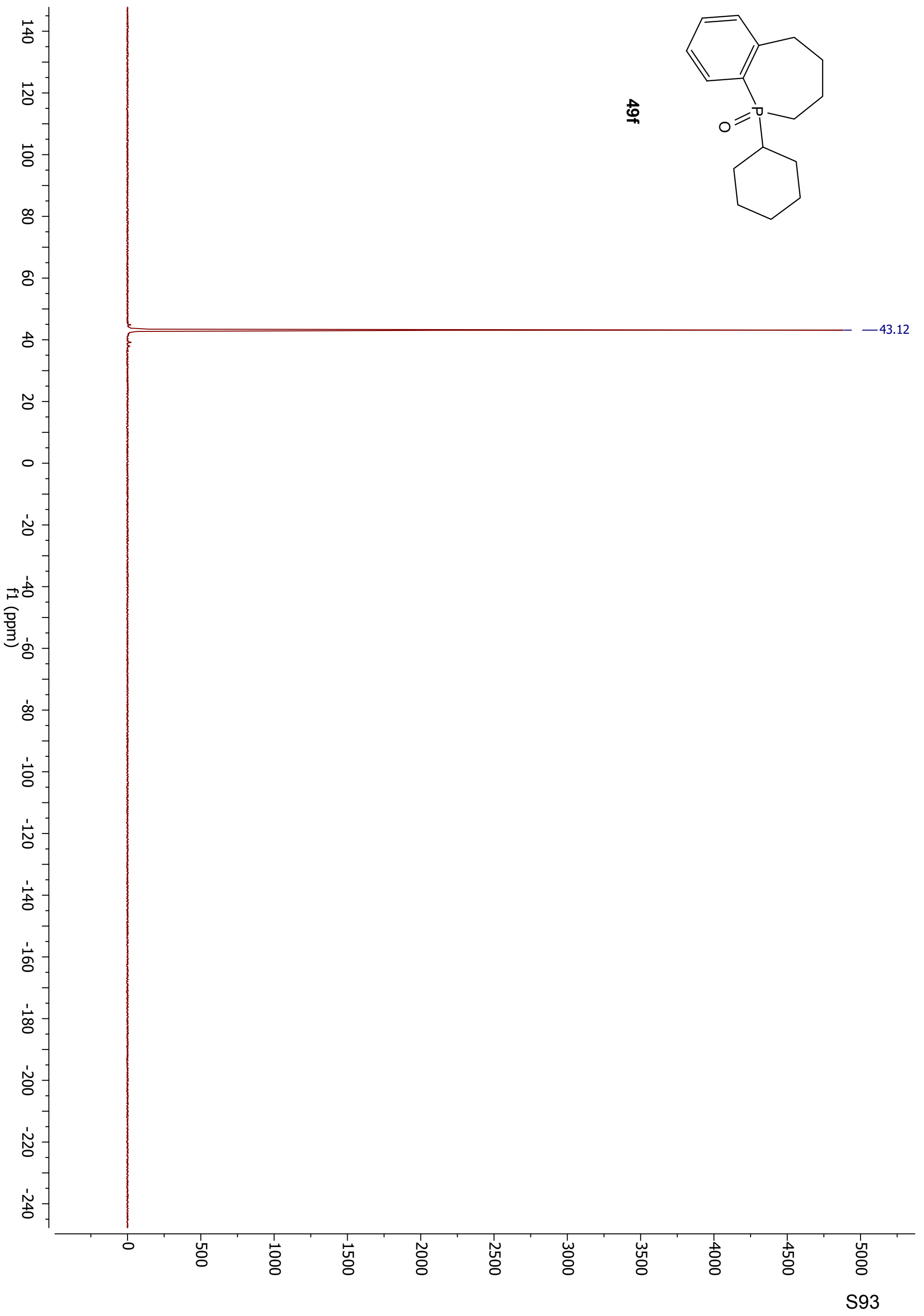




$$
18
$$




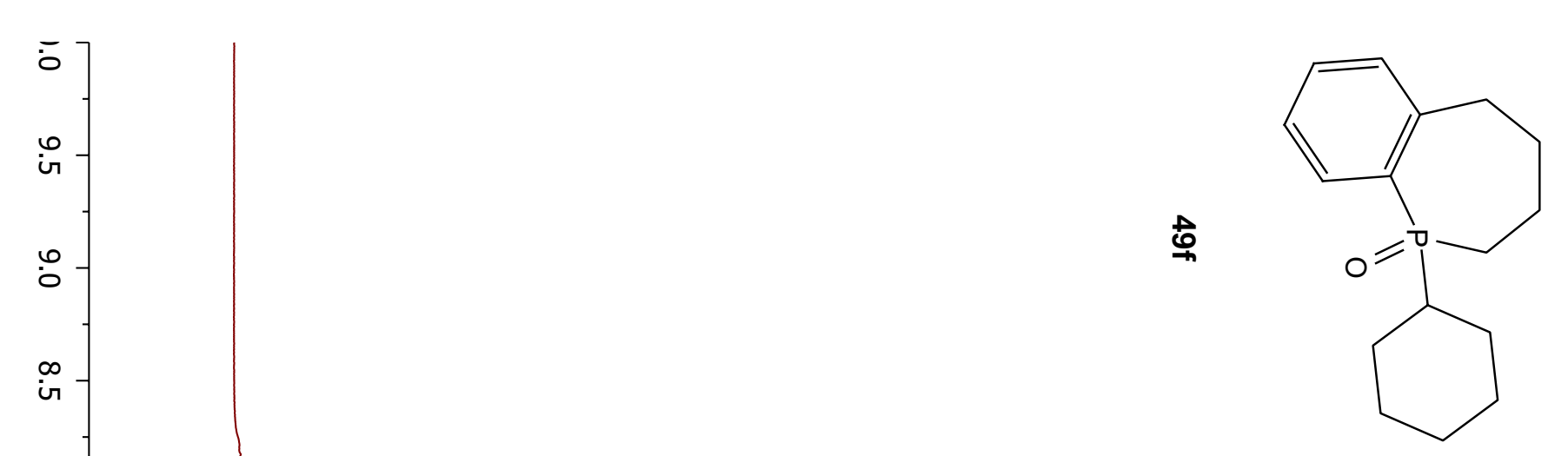

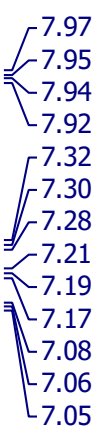

4.17

-4.16
-4.15

4.14

$-4.13$

$-4.12$

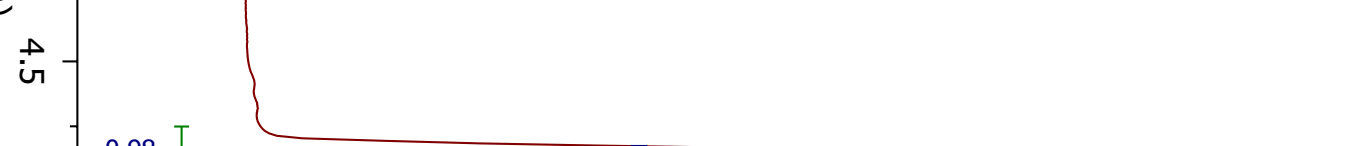

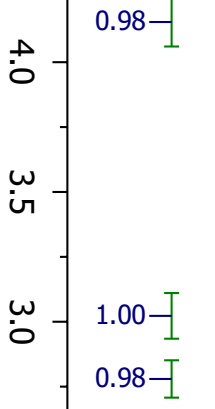

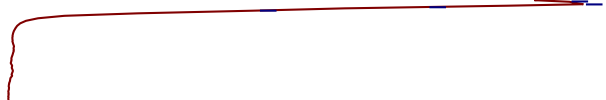

N $6.56-$
$1.22=-$
$9.98--$

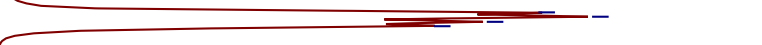

$-1.54$

$-1.50$

$-1.48$

1.47

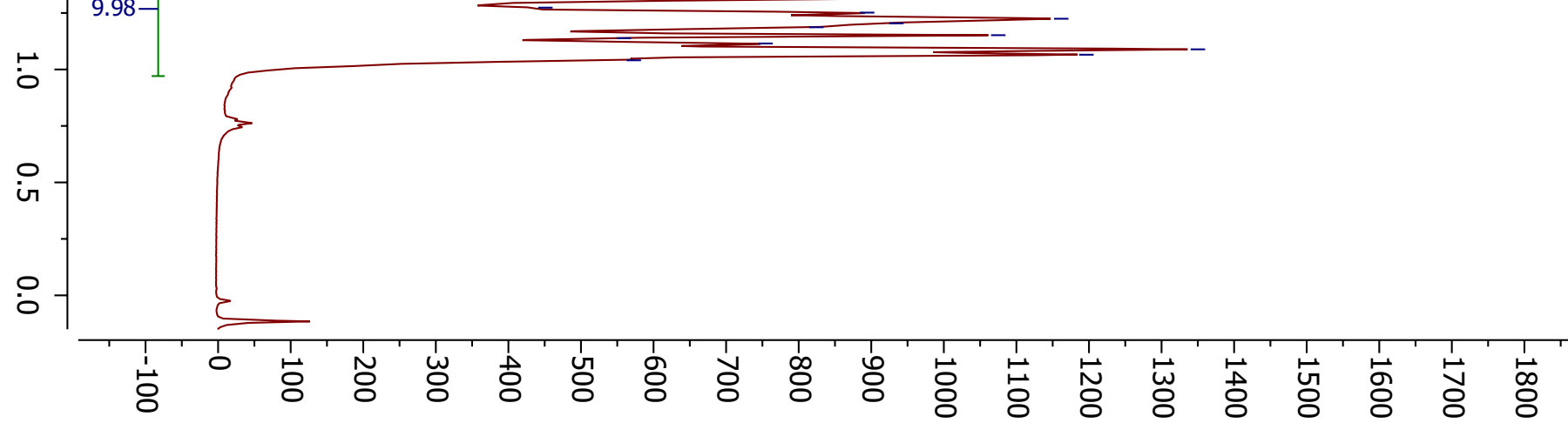

1.27

1.25

$-1.22$

$-1.20$

$-1.19$

1.15 


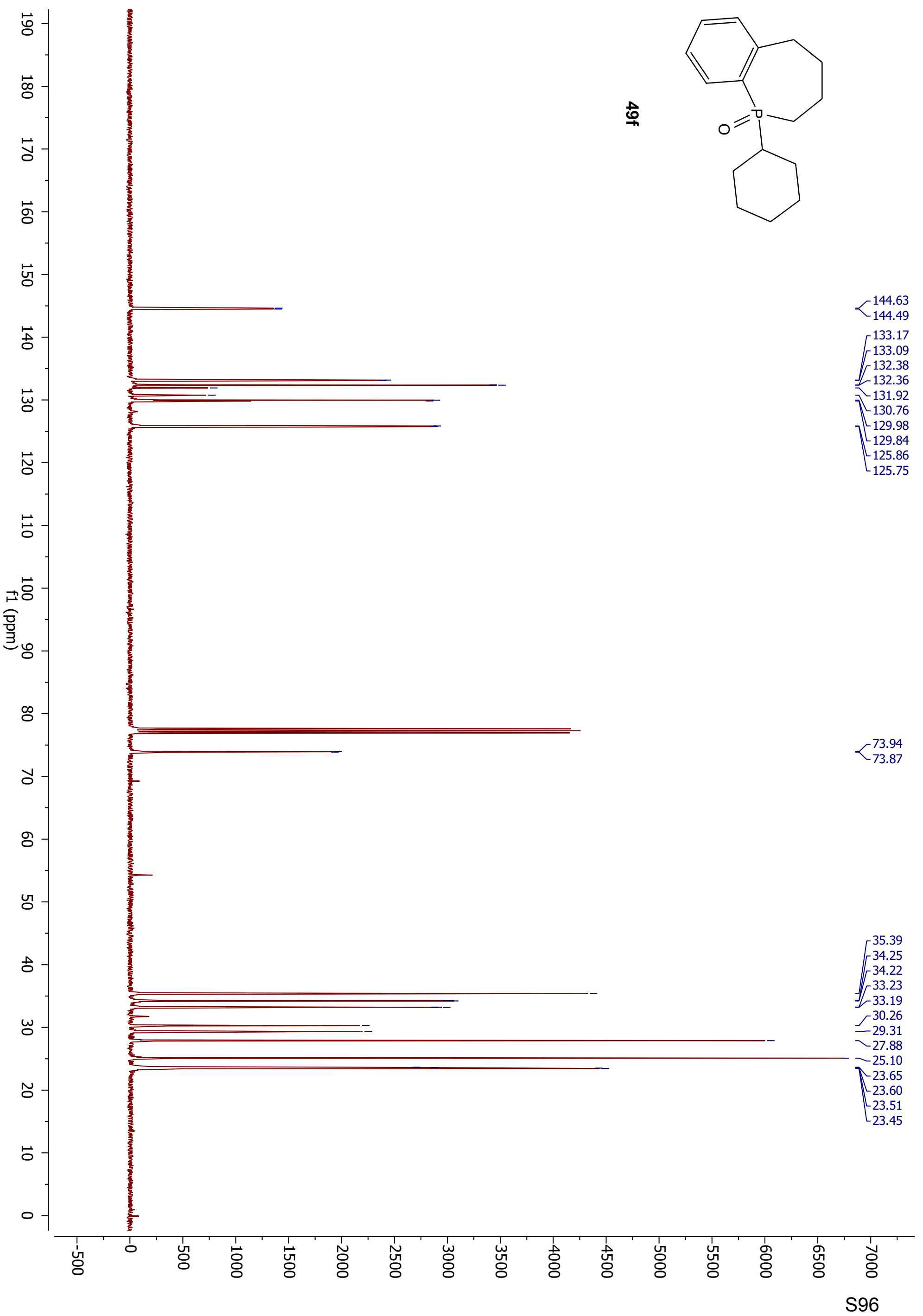



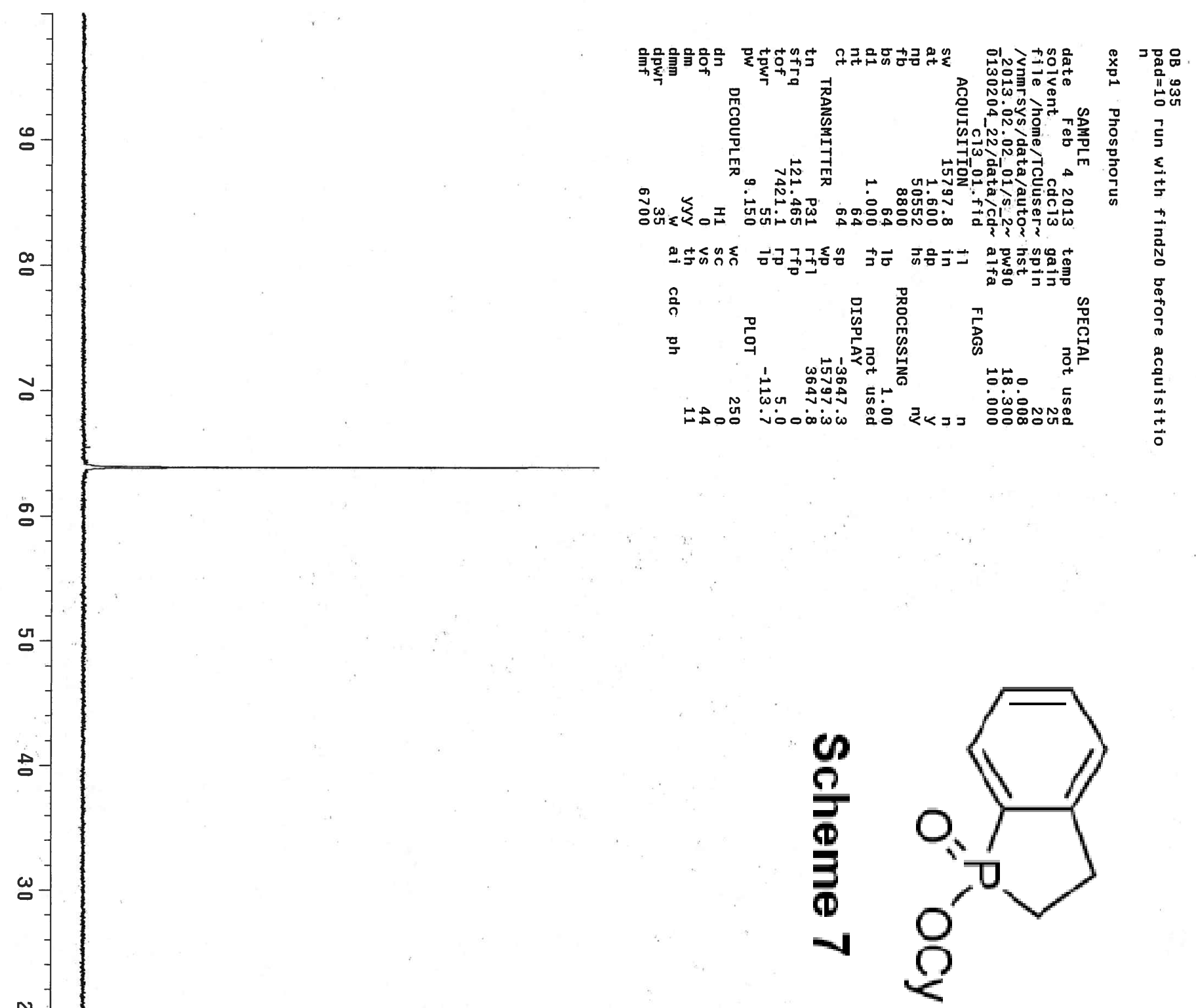



듬

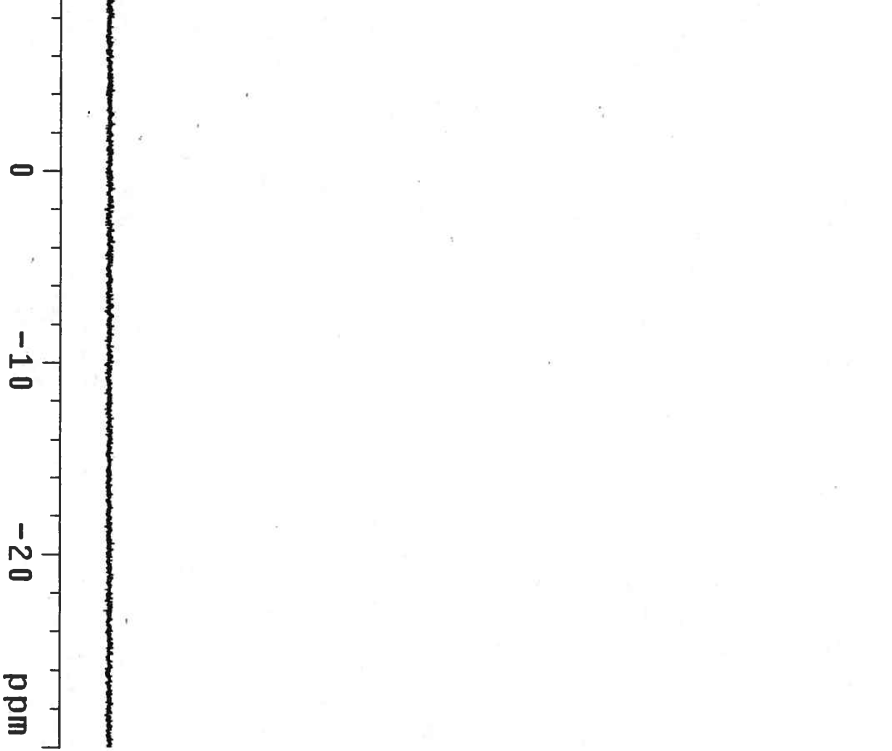




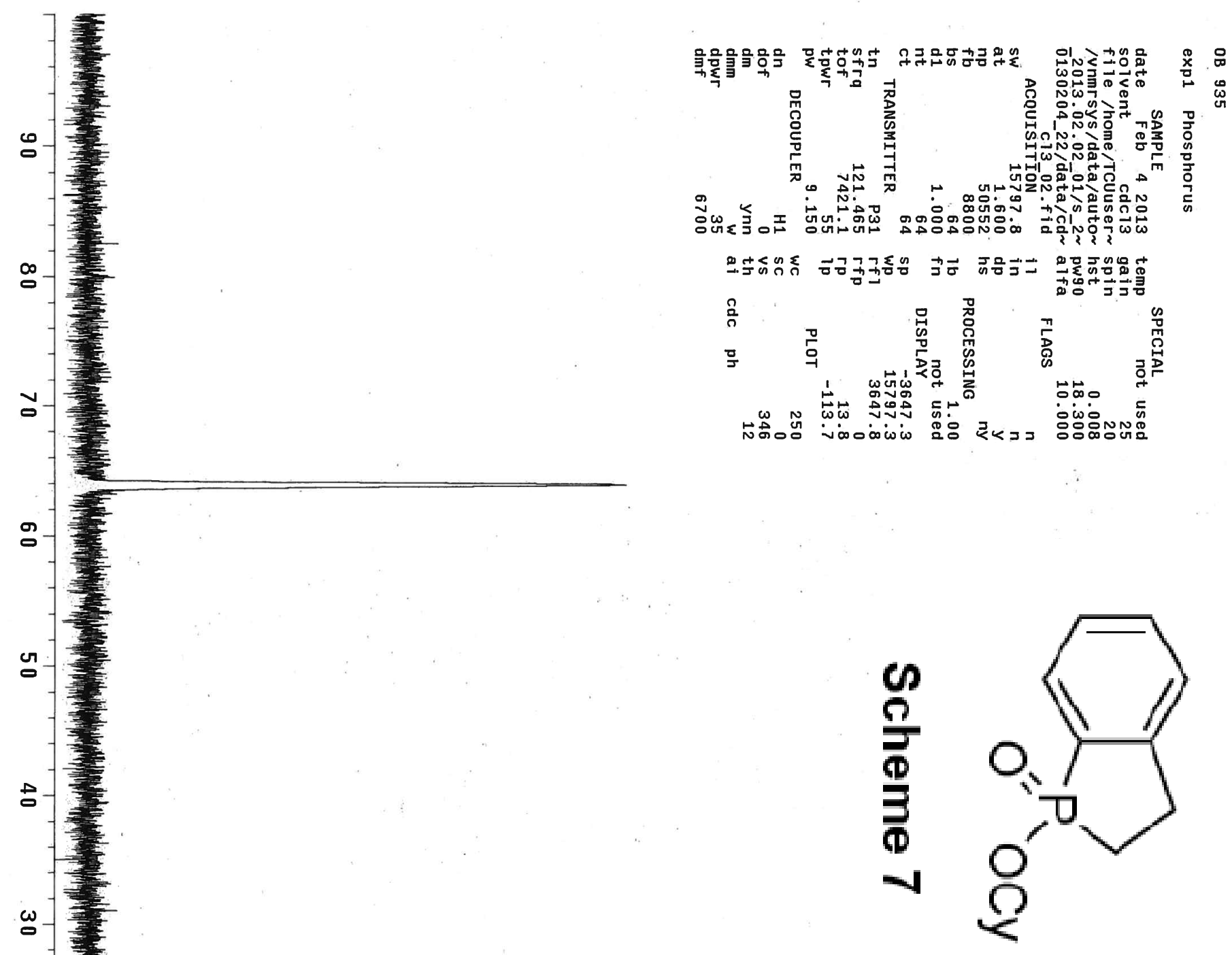




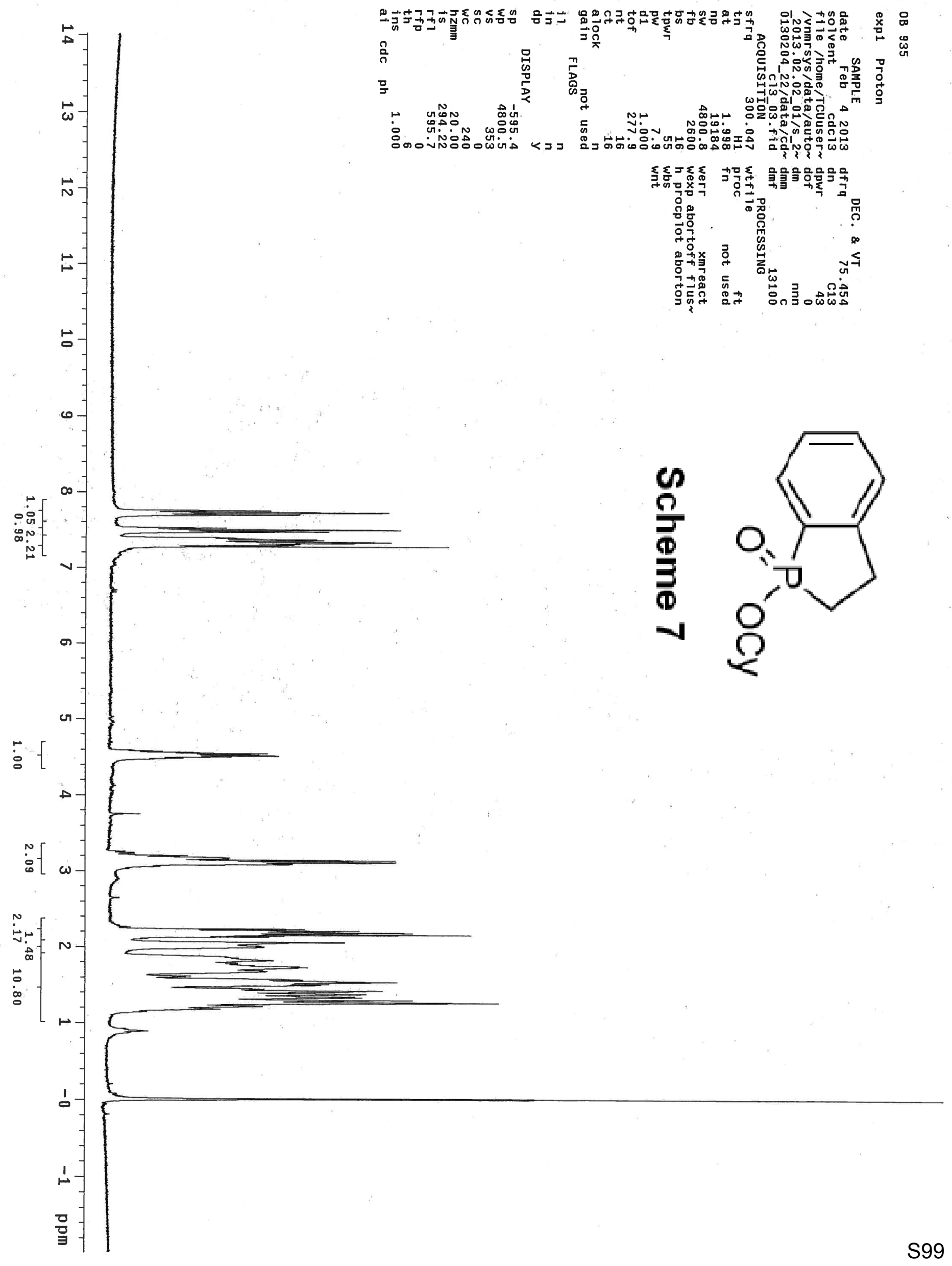



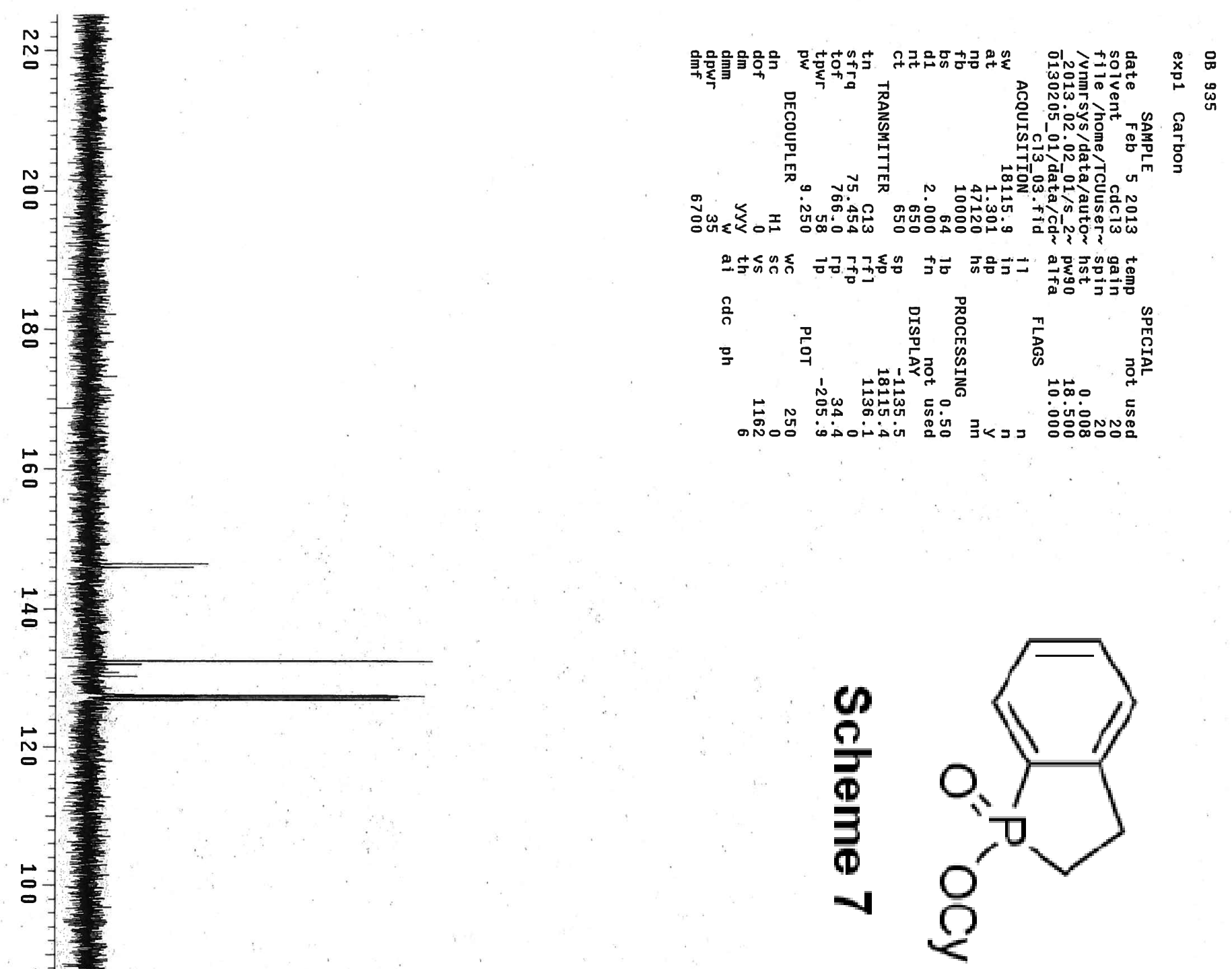

$\infty$

$\stackrel{\infty}{\circ}$

$\stackrel{\circ}{\circ}$

芴

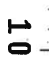

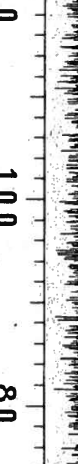

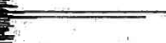

-

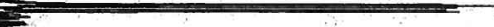

o

$\circ-$

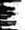

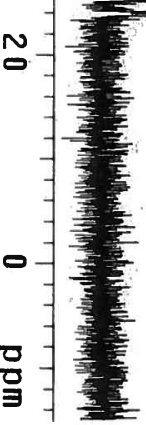




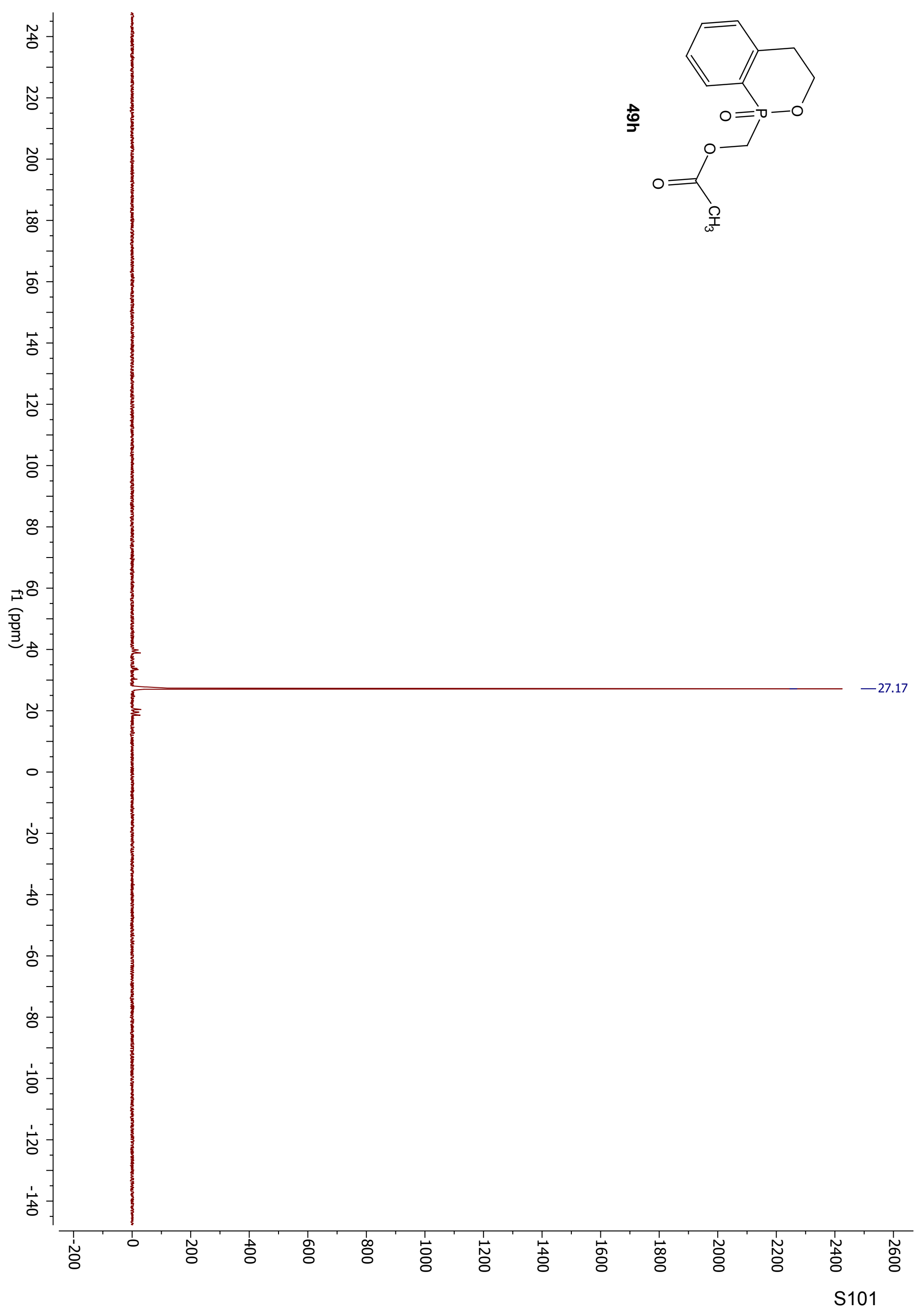




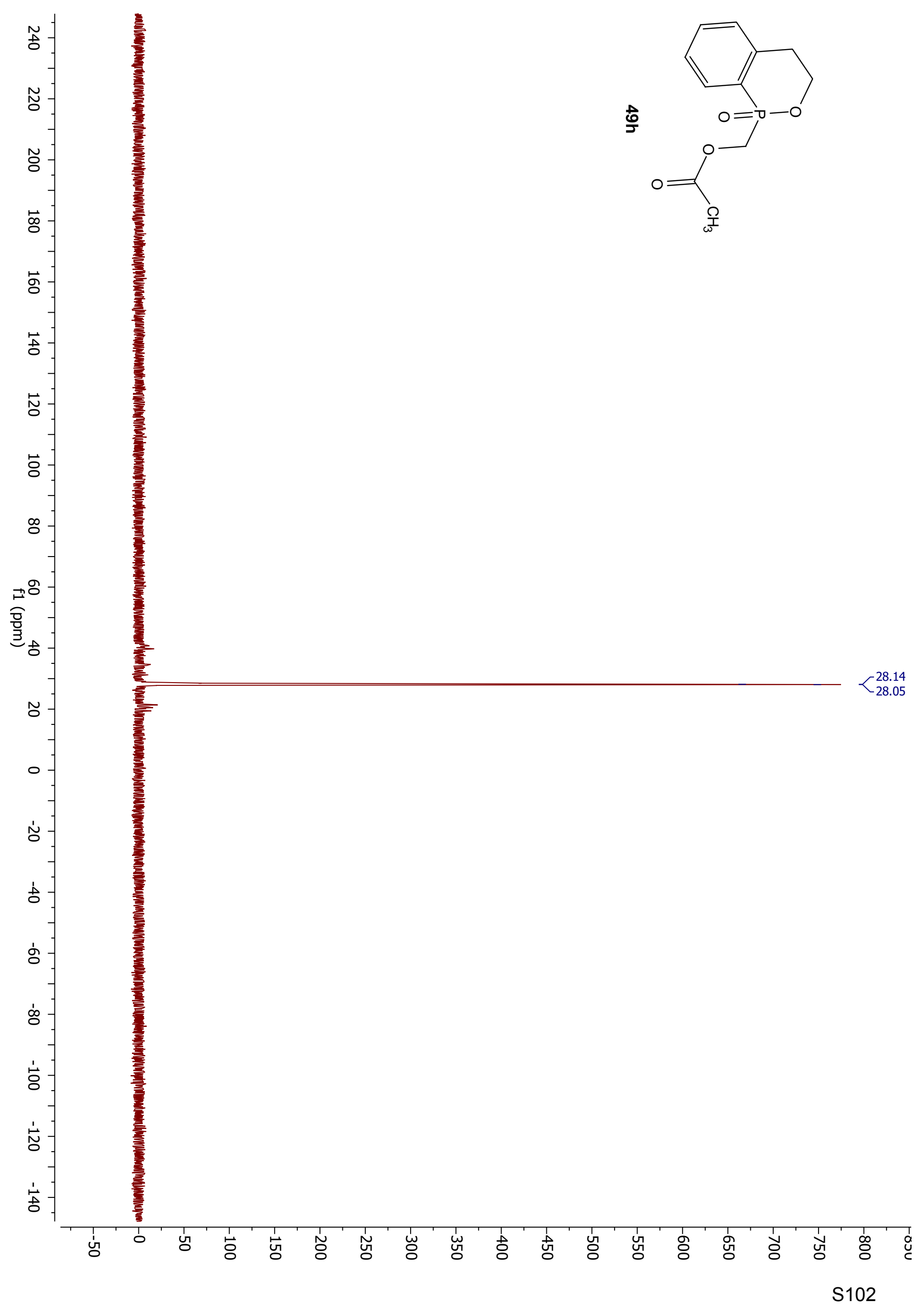




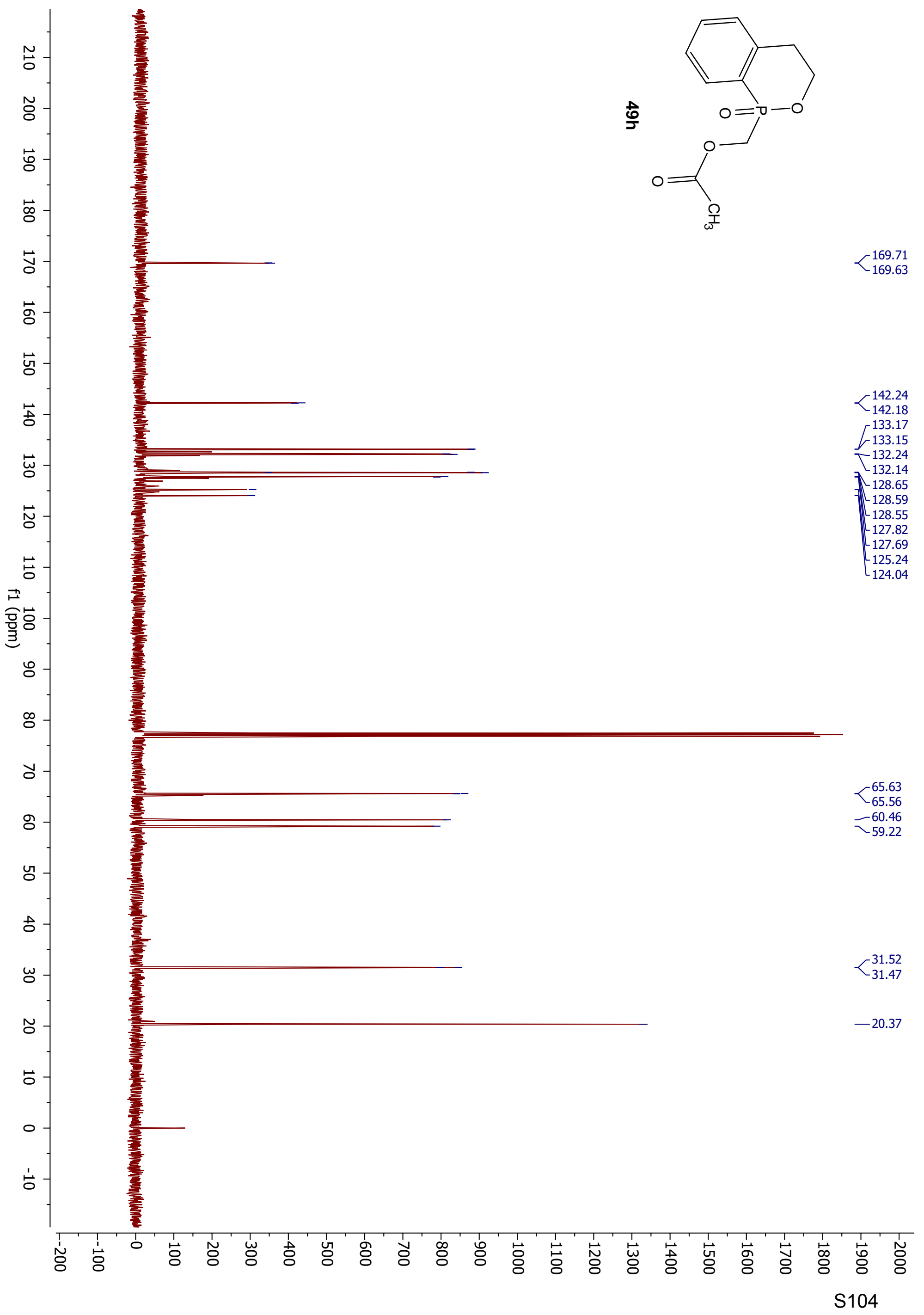




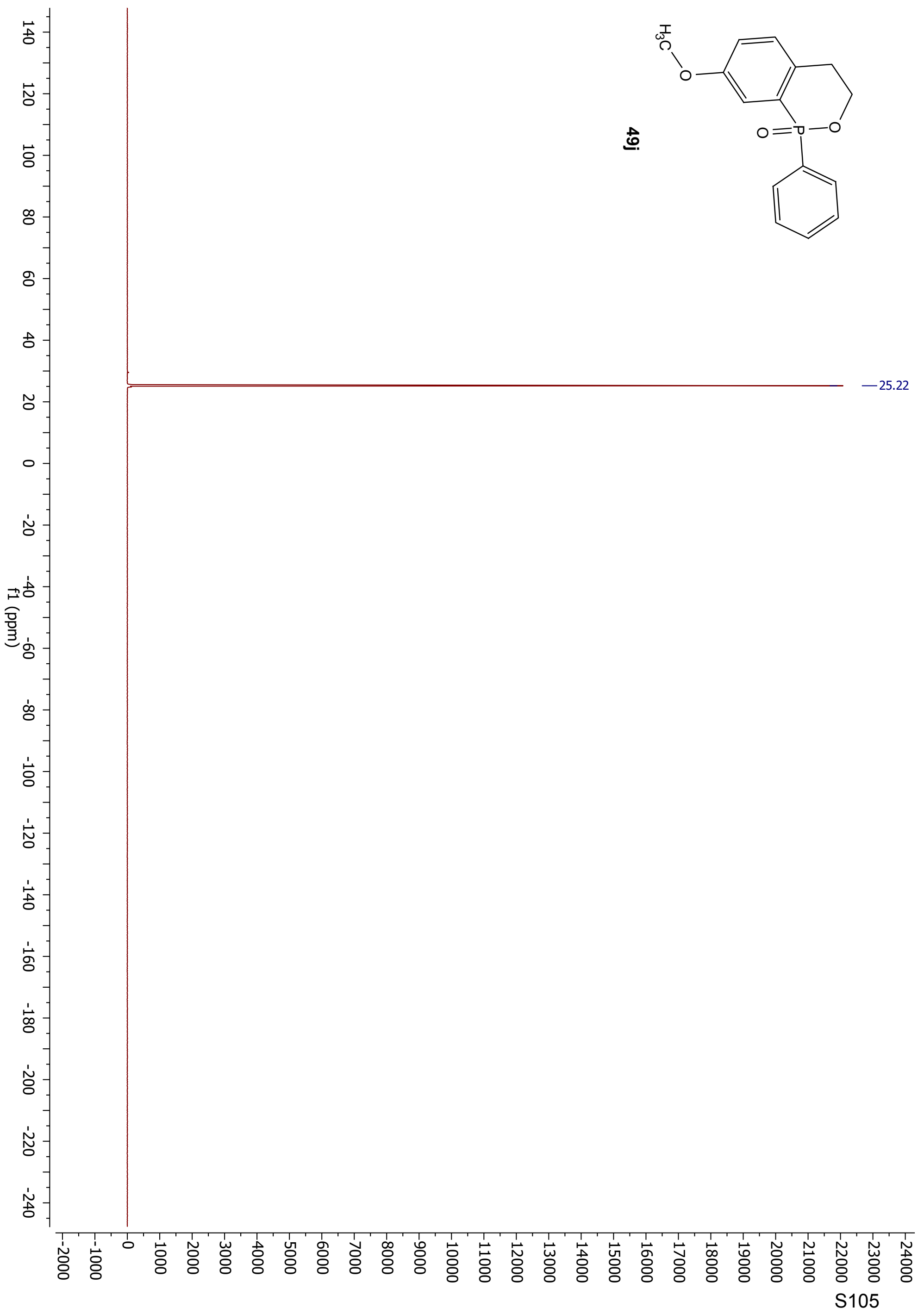




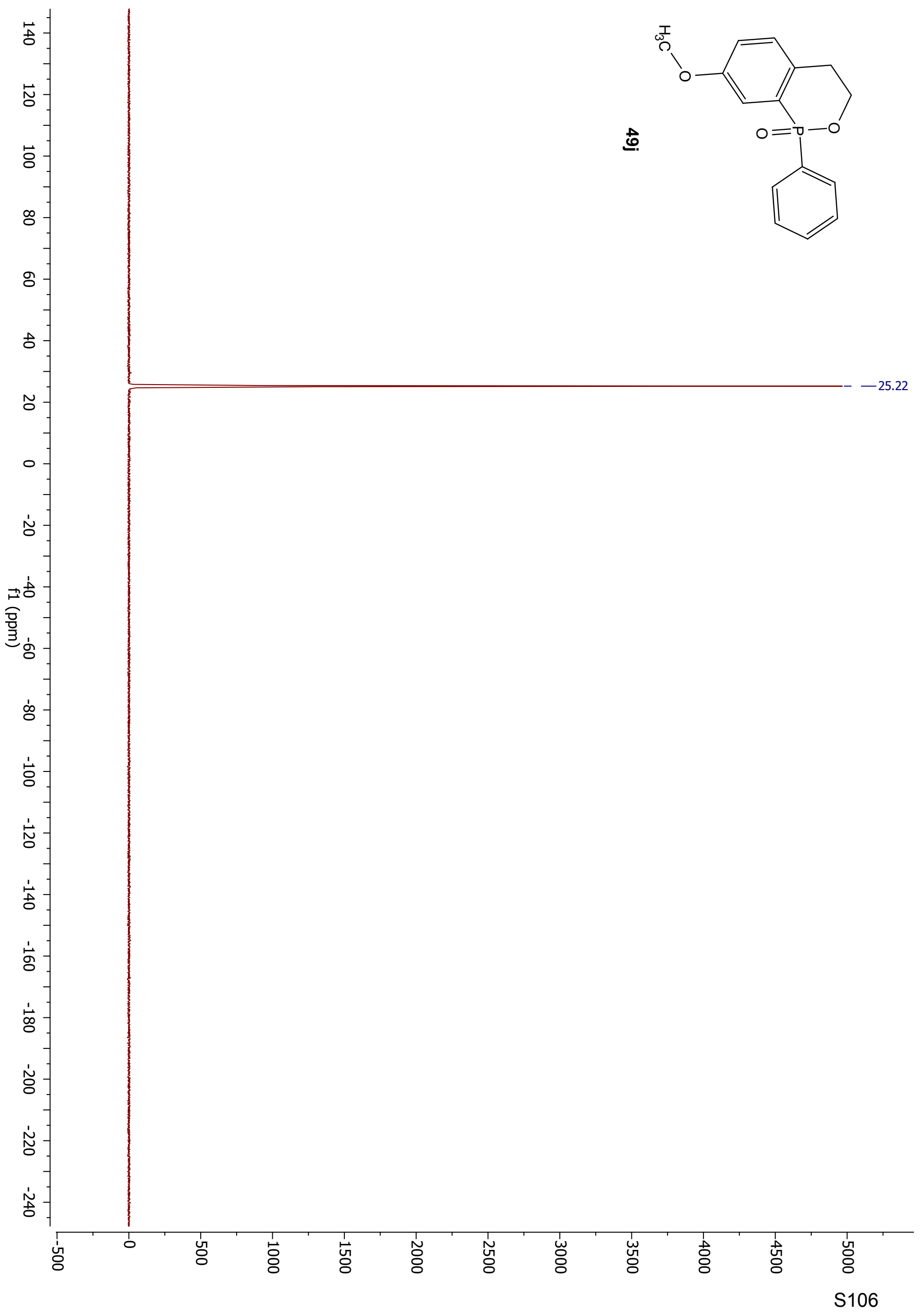




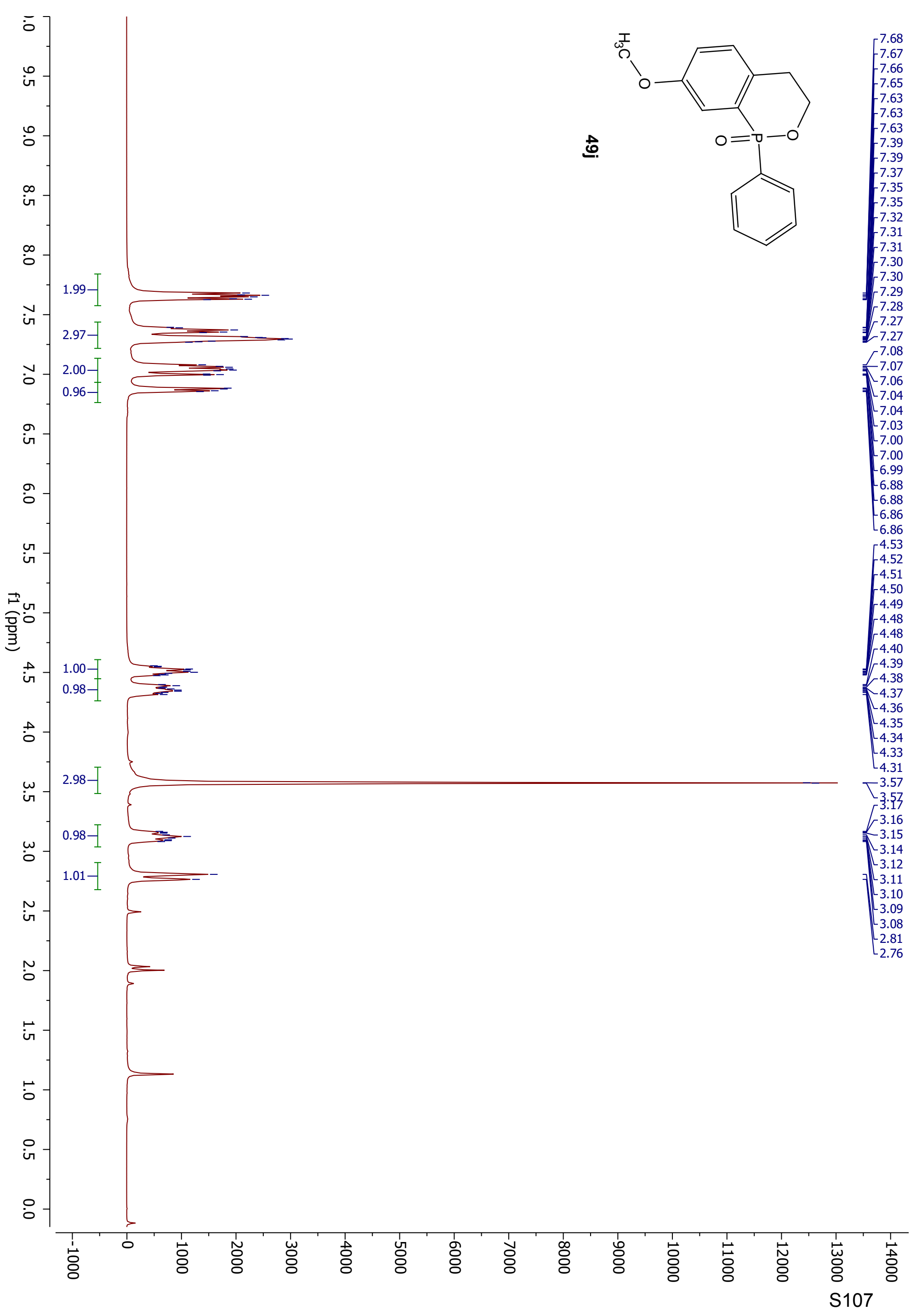




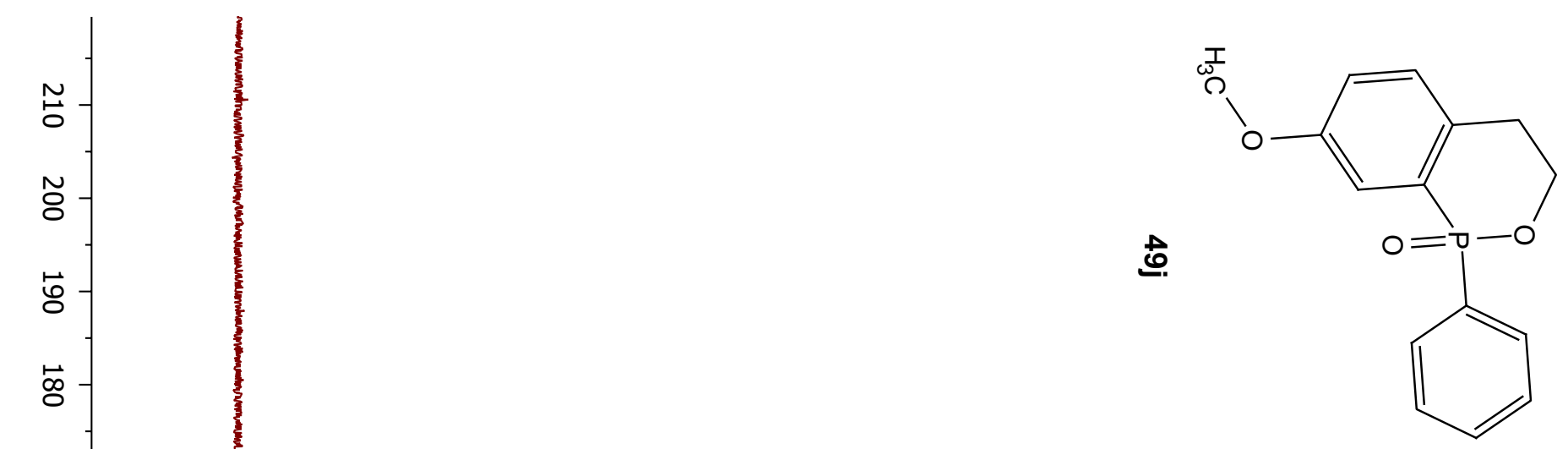

158.58

158.42

133.20

$-133.15$

$-132.36$

132.33

$-132.18$

tै

宫

$\stackrel{\omega}{\circ}$

ัํำ

용

害宫

8

$\varnothing$

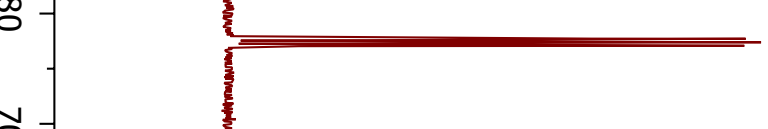

๖

8

?

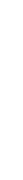

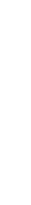

w
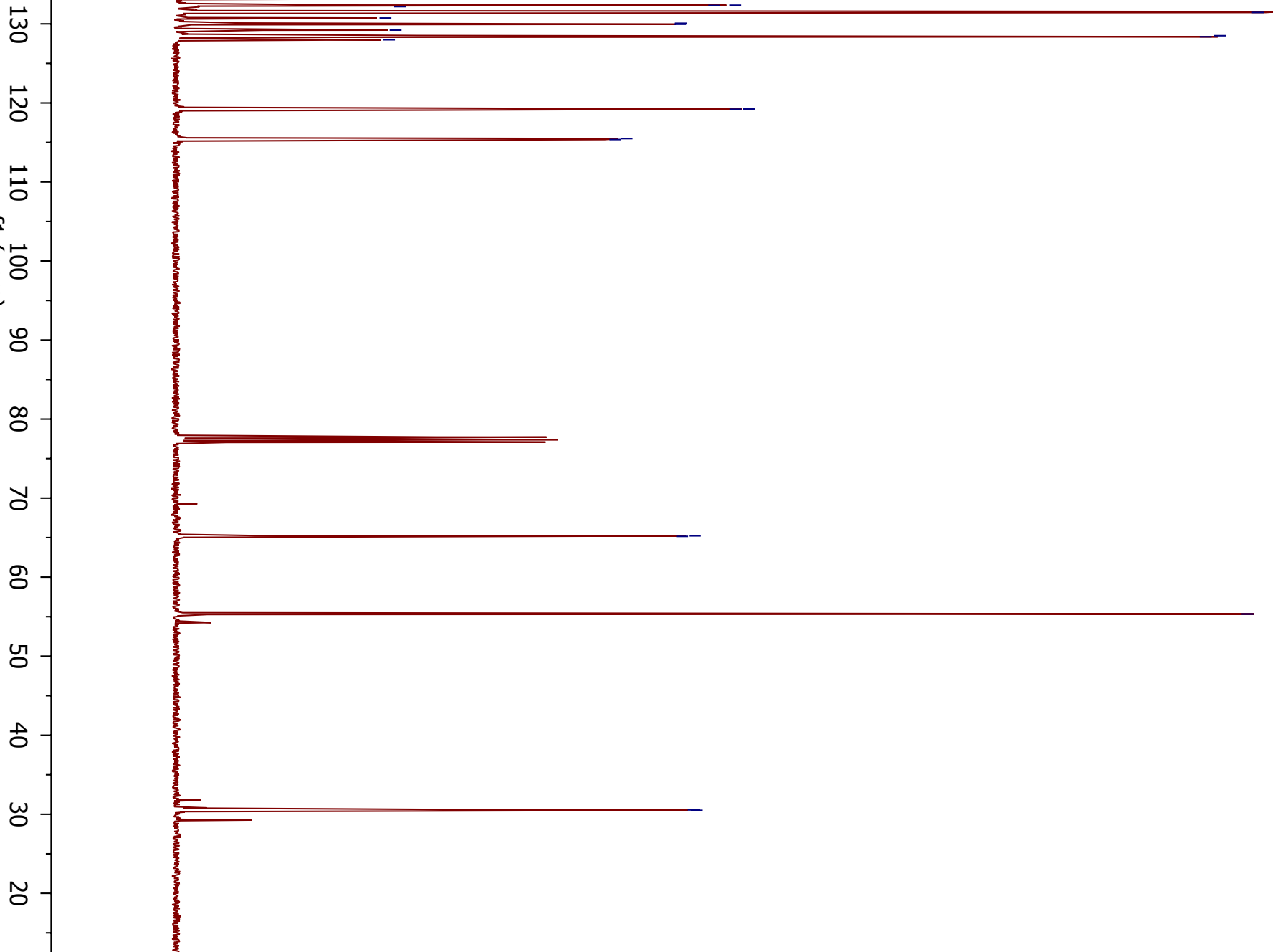

131.55

$-131.44$

$-130.74$

130.07

129.95

129.21

128.50

$-128.37$

127.98

119.23

119.20

115.49

115.37

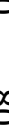

เ

。

它

它-

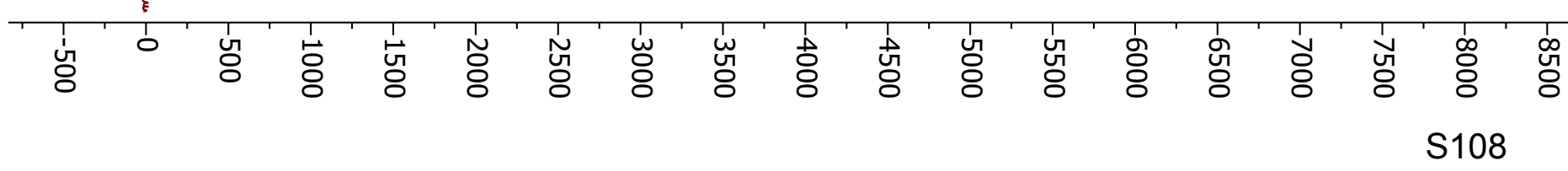




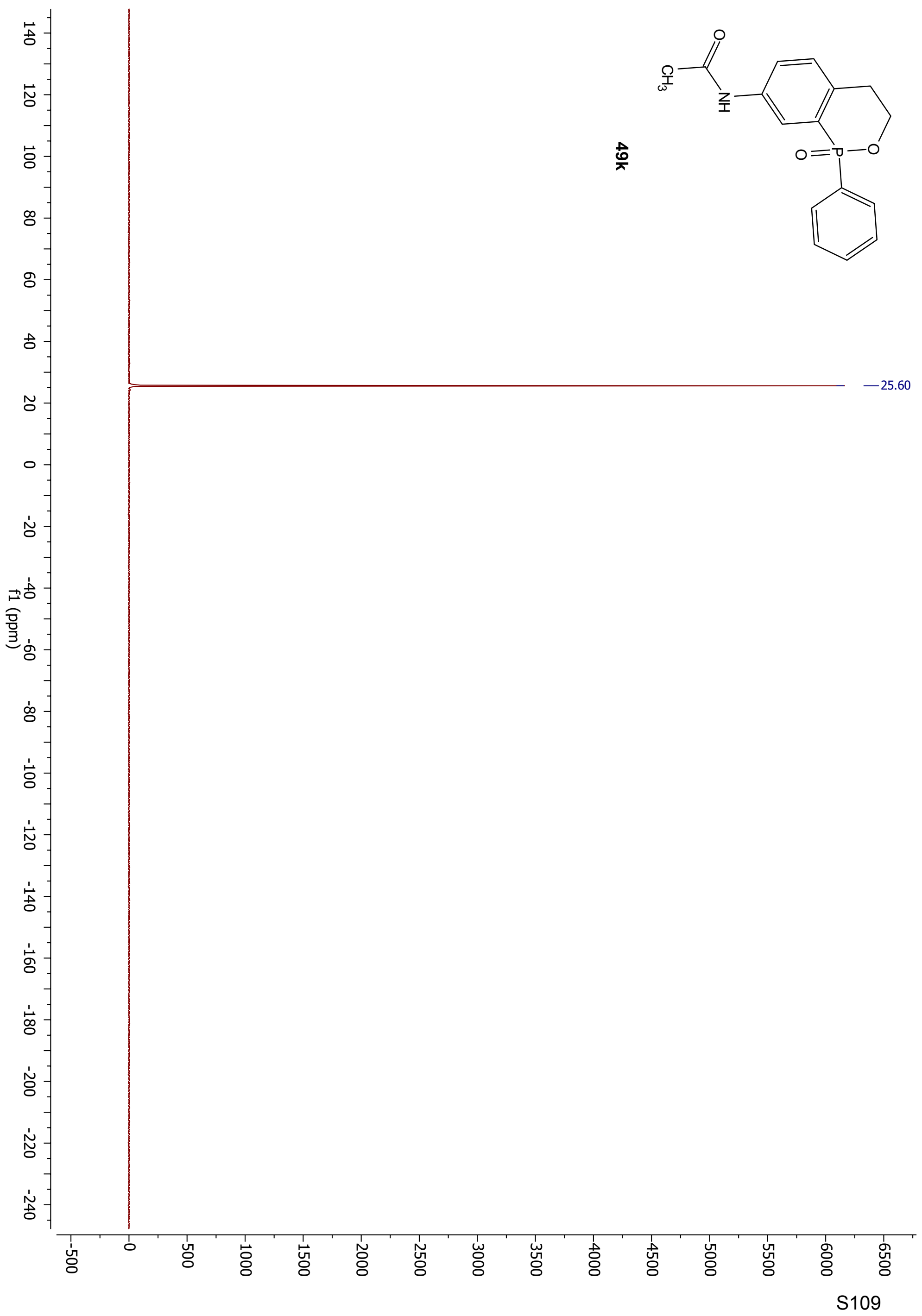




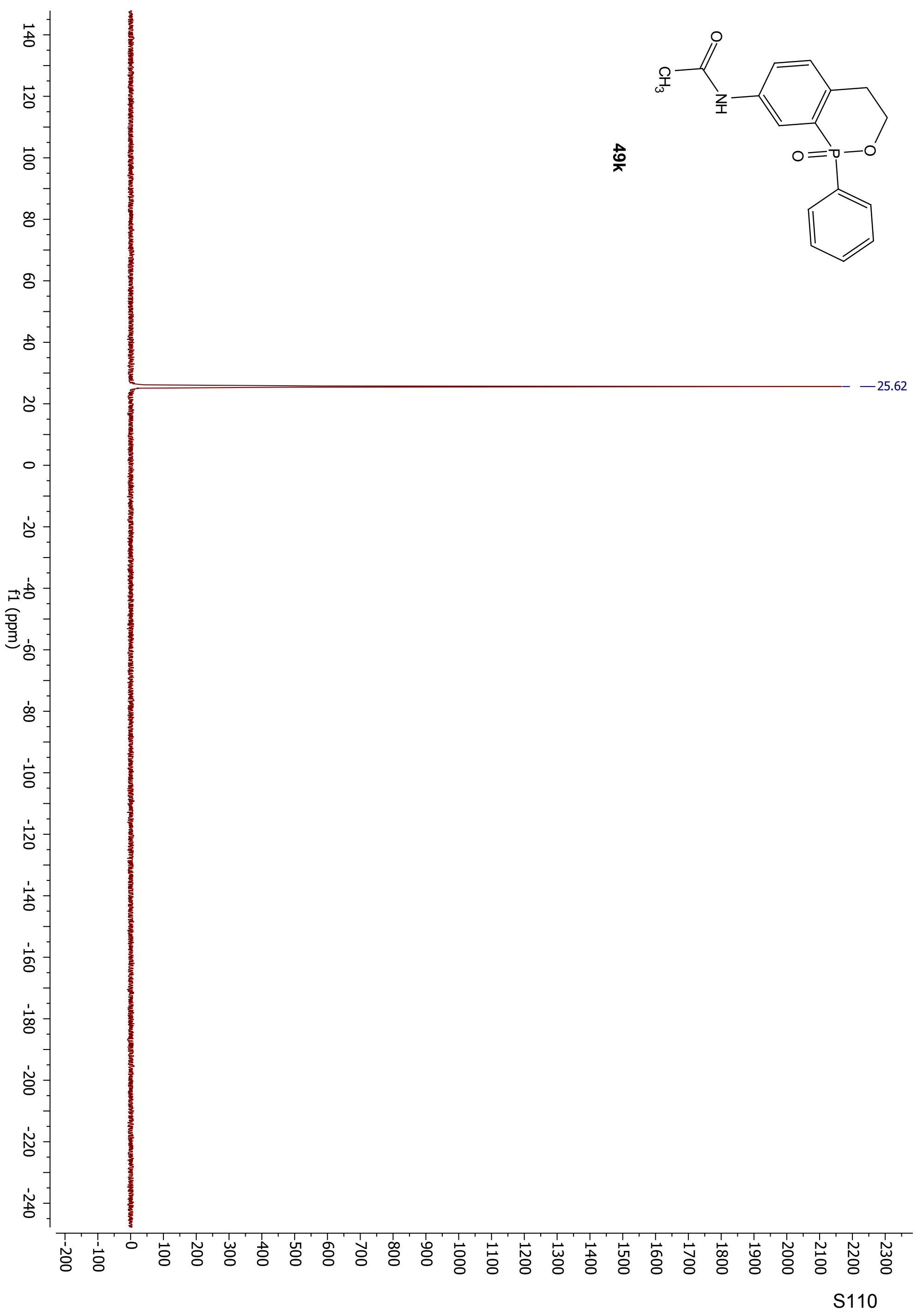




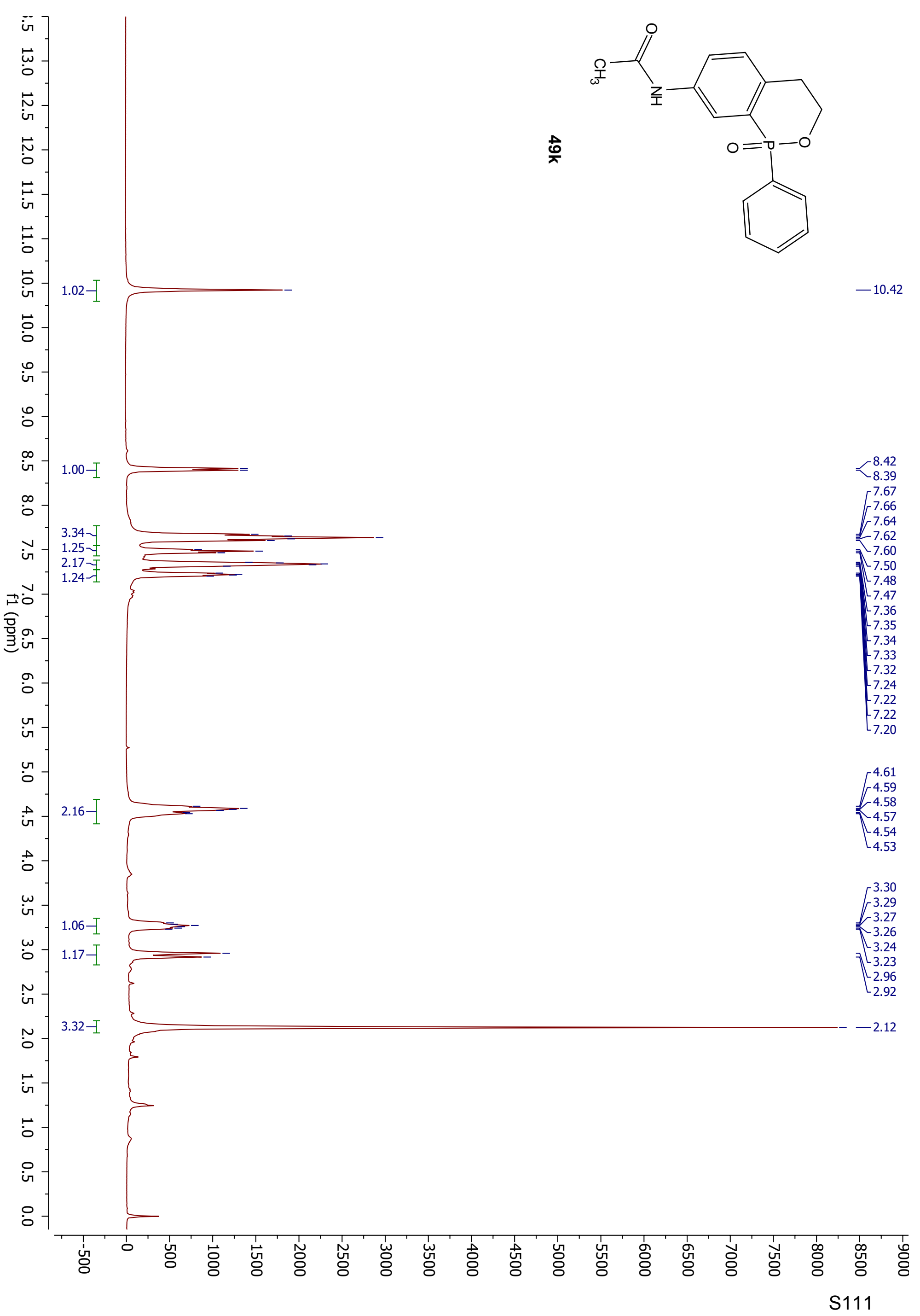




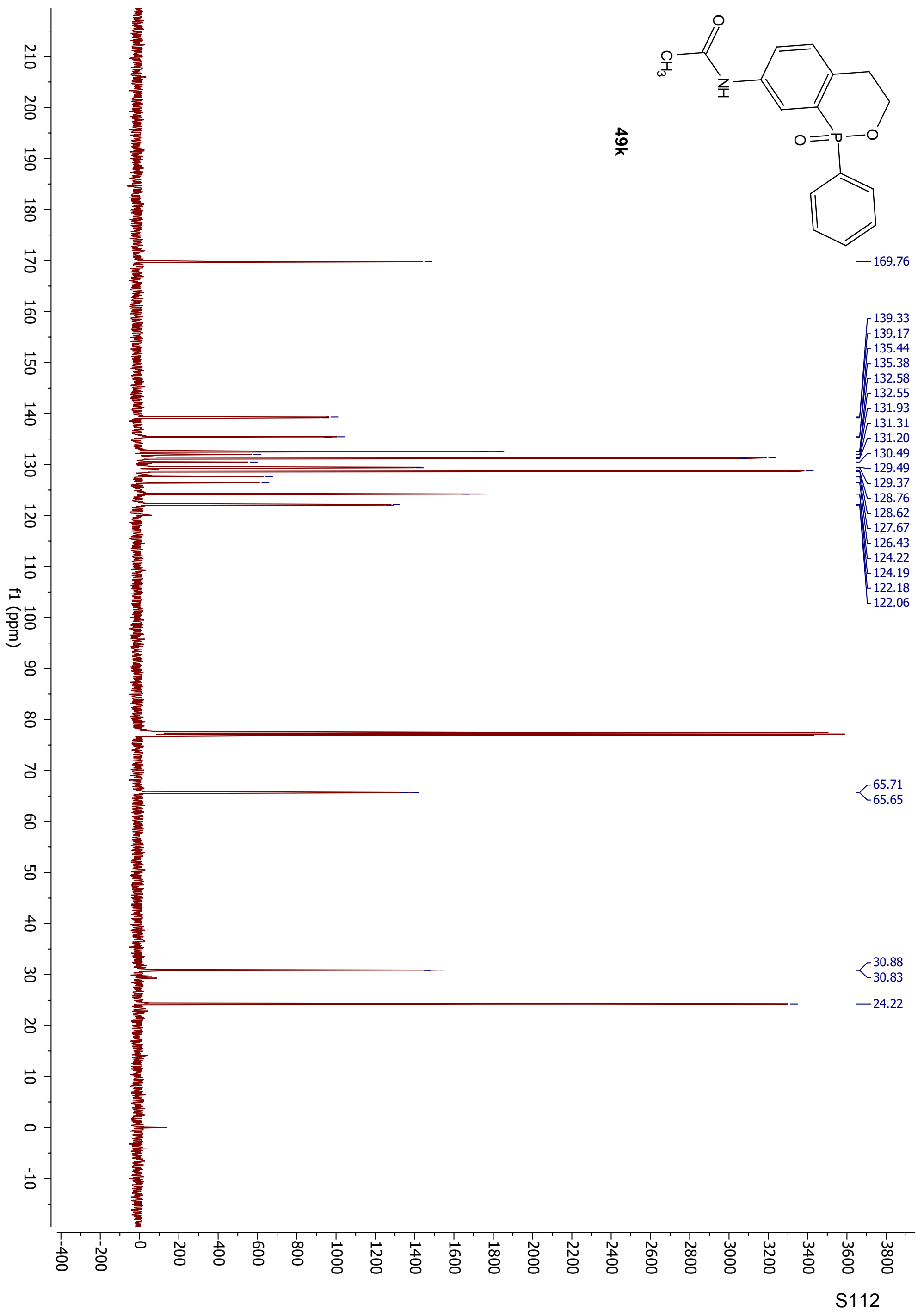




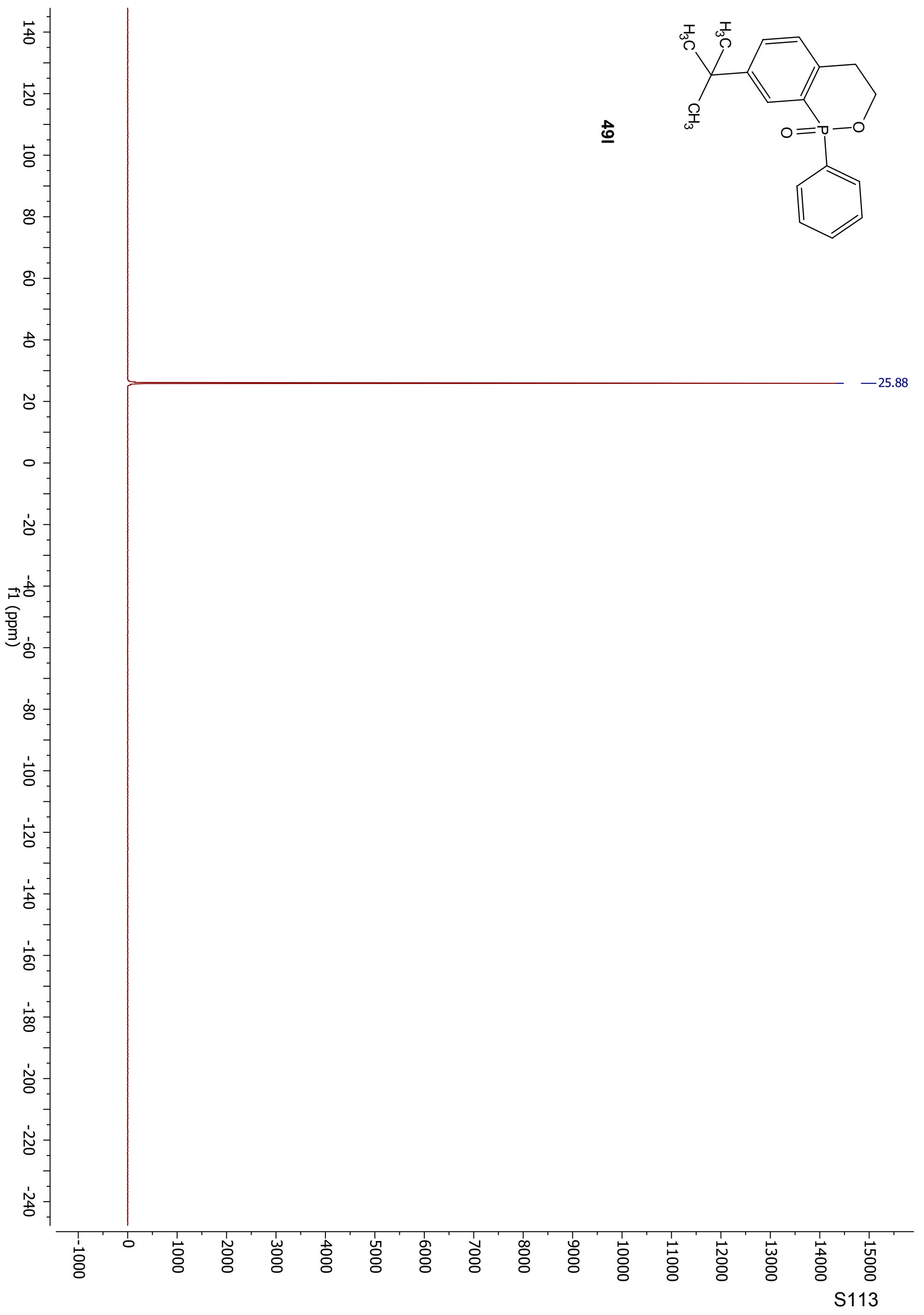




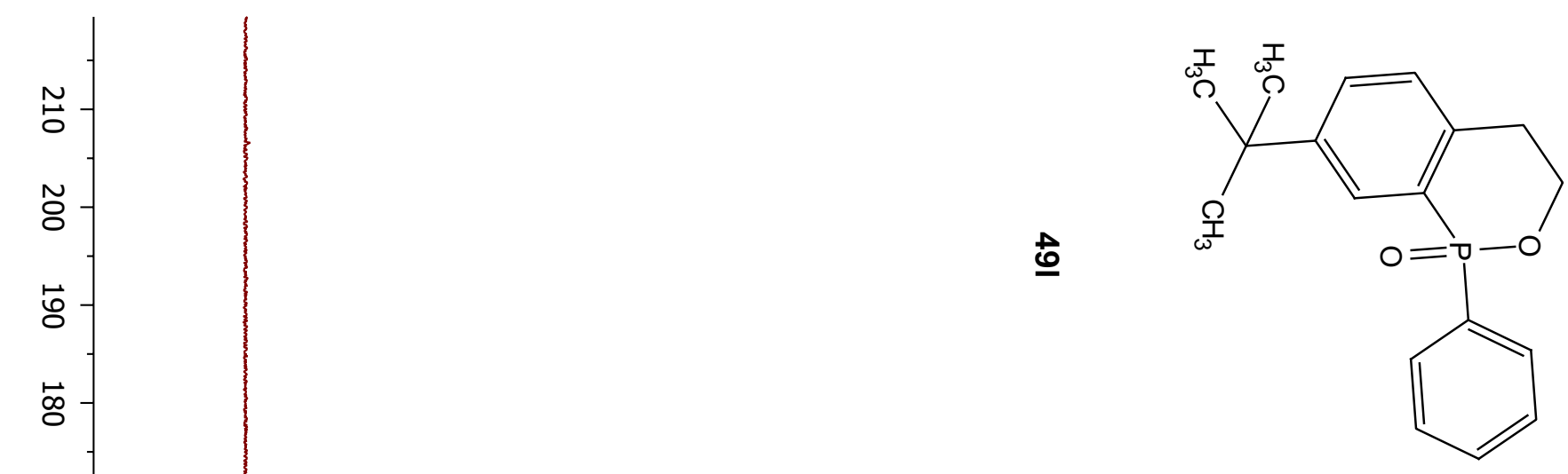

홈

8

$\infty$

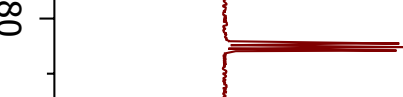

๖

8

v

음

$\approx$

๖

官

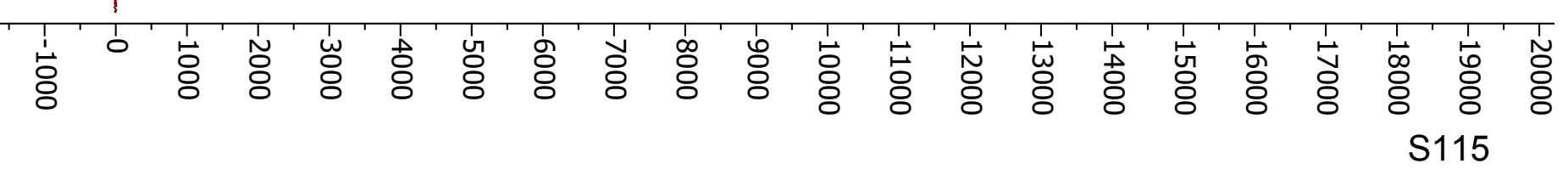




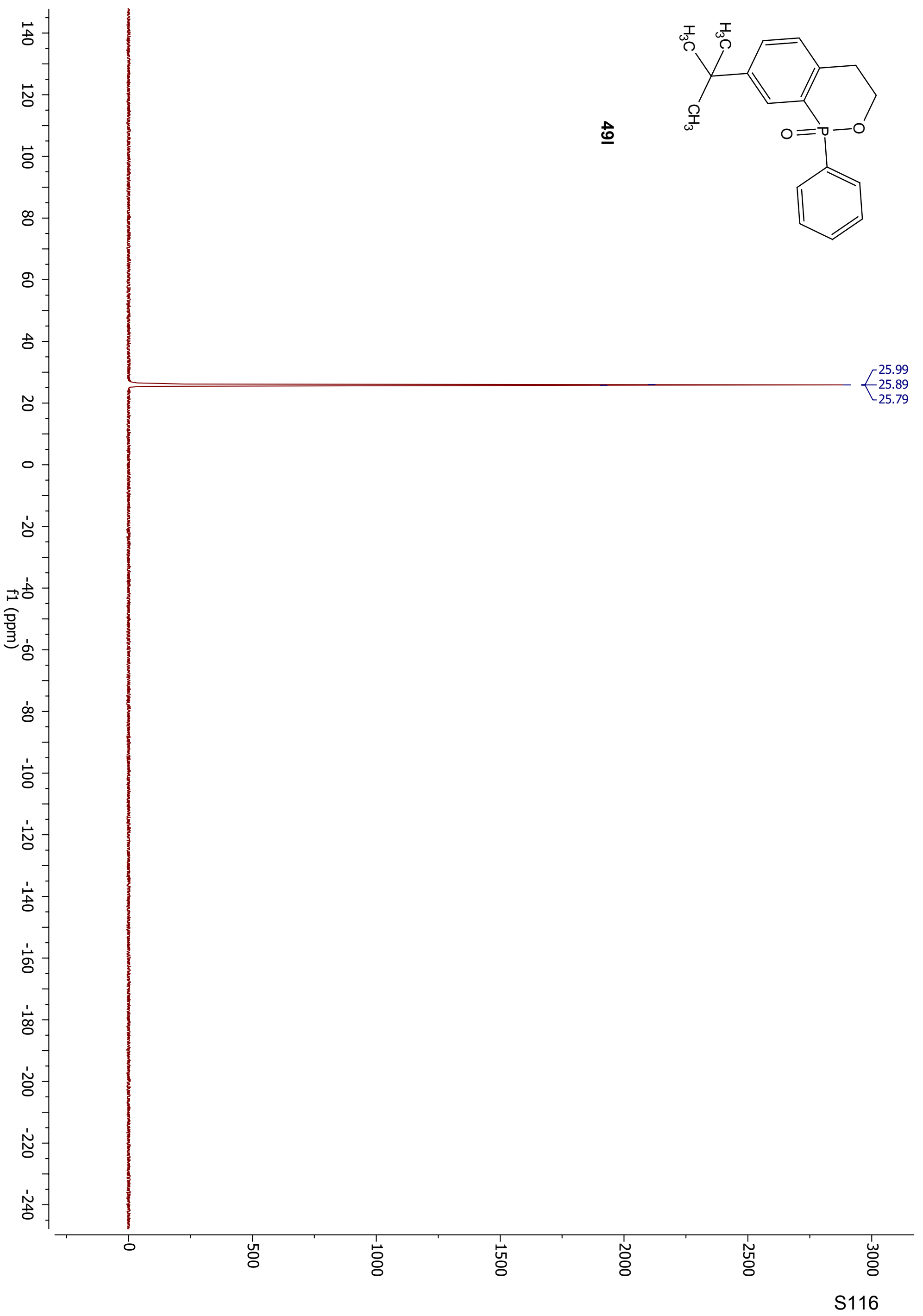

